Historic, archived document

Do not assume content reflects current scientific knowledge, policies, or practices. 



\section{SEED HEADQUARTERS}

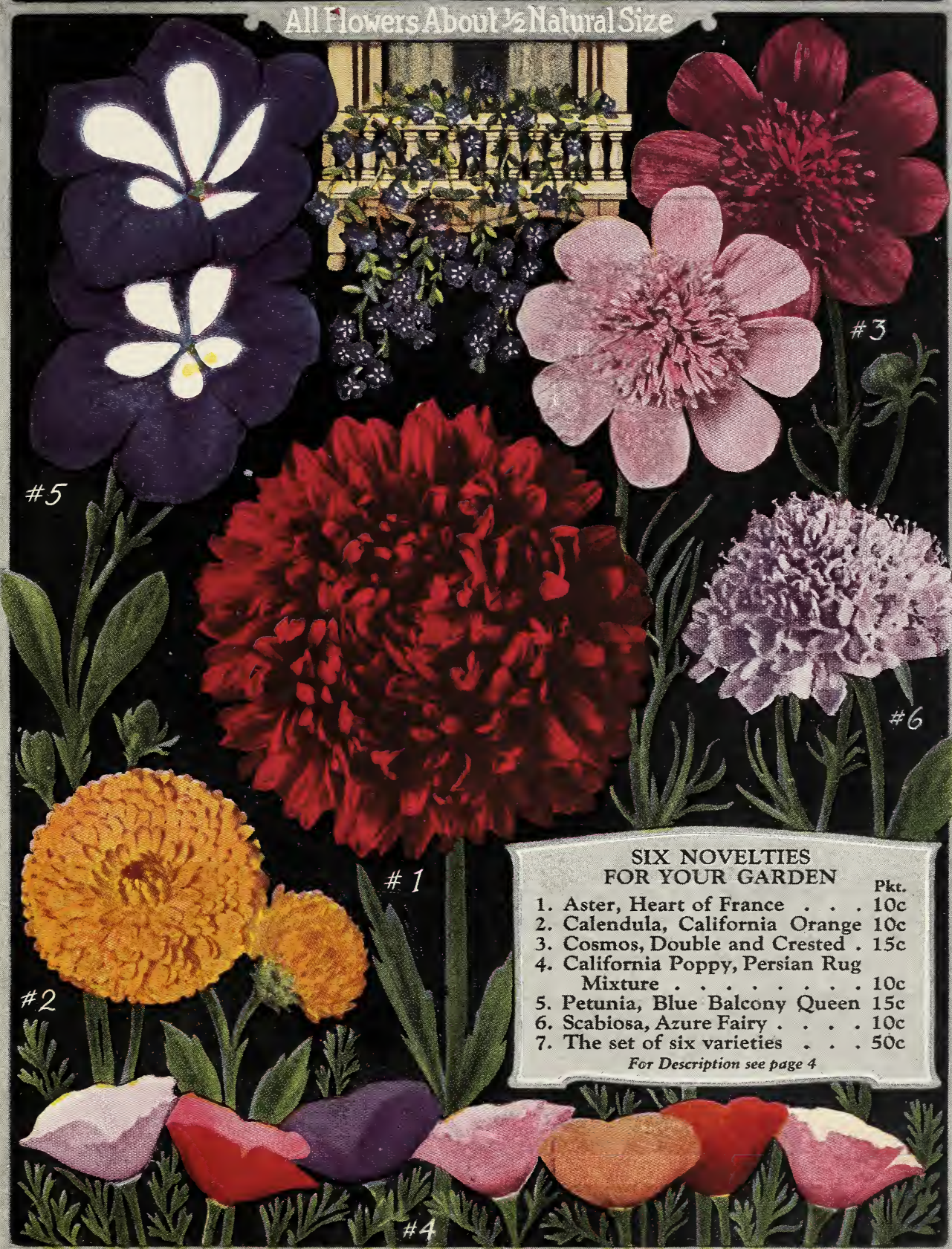




\section{“BETTER GARDENS”}

Have you ever heard people say, "I wish I had the 'luck' Soand-So has with gardening"? If you happen to be the person of whom this is said you know that it is not a case of 'luck' but rather of knowing how. We run across this remark so often that we have prepared a 64-page book to show just how to do things right.

Fifty-seven recipes for cooking; instructions on canning, dry-

ing and storing vegetables; planting suggestions on all classes of bulbs, shrubs, roses, roots, vines and small fruits: a chart showing detailed culture, where to plant, blooming period and height of 63 classes of flowers; all these things and many more are included to make up this book.

Use this book as your garden guide and your friends will talk about your 'LUCK' in gardening. Be sure to order a copy.

No. 42. Book, Better Gardens. Free with \$2.00 orders. 25c. copy

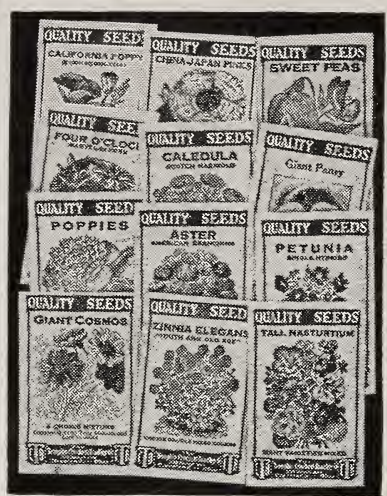

\section{Twelve Favorite Flowers}

You surely will have room for at least a few flowers in your garden this year. This collection, No. 43, is made up of the varieties in greatest general demand. They are easy to grow and equally desirable for display in the garden and for cut flowers for bouquets in the house. No substitution or change of varieties will be permitted.

1 Pkt. ASTER, Extra Quality, Double Mixture, All Colors 10 cts

1 Pkt. GALENDULA, Scotch Marigold, Finest Mixed Colors 5 cts

1 Pkt. GALIFORNIA POPPY or ESCHSGHOLTZIA, Finest Mixed $5 \mathrm{cts}$

1 Pkt. COSMOS, Early Large Flowering, All Colors 5 cts

1 Pkt. GHINA and JAPAN PINKS, Dbl. and Single, Many Varietes $\mathbf{5}$ cts

1 Pkt. FOUR O'CLOCK (Marvel of Peru) All Colors Mixed 5 cts

1 Pkt, NASTURTIUM, Tall or Climbing, All Colors 5 cts

1 Pkt. PETUNIA, Choice Single Hybrids, Mixed 5 cts

1 Pkt. POPPIES, Double and Single, An Unrivaled Mixture 5 cts

1 Pkt. SWEET PEAS, Superb Grandiflora, Large Flowering Mixture 5 cts

1 Pkt. VERBENA HYBRIDA, All Colors, Finest Mixtures 5 cts

1 Pkt. ZINNIA ElEGANS, Double, Finest Mixed Colors 5 cts

No. 43. Favorite Flowers, Postpaid 50cts. A collection would make a neat gift to some gardening friend.

\section{\$1. The 24 Best Selling Vegetables \$1.}

If you asked us to help select the vegetable seeds for your garden, we know of no better way to serve you than to just offer the 24 varieties which were our BIGGEST SELLING VEGETABLE SEEDS last year. Because of the large number of these collections which our customers order each year,

we can offer you this $\$ 1.42$ worth of seeds for only $\$ 1.00$. This collection will not only save you money but will help you to plant just the right kinds. Every packet is taken from our regular stock and all are guaranteed to please you. No sub-

\section{Look at this Splendid Assortment}

1/4 lb. BUSH BEAN, Imp. Golden Wax $10 \mathrm{cts}$

1 Pkt. BEET, Grosby's Egyptian $\quad 5$ cts

1 Pkt. GABBAGE, Early Jersey Wakefield 5 cts

1 Pkt. GABBAGE Prem. Late Flat Dutch 5 cts

1 Pkt. GARROT, Danver's Half Long $5 \mathrm{cts}$

1 Pkt. CELERY, Giant Paschal $5 \mathrm{cts}$

$1 / 4$ lb. SWEET GORN, Golden Bantam $12 \mathrm{cts}$

$1 \mathrm{oz}$. POP CORN, Japanese Hulless $5 \mathrm{cts}$

1 Pkt. GUCUMBER, Imp. White Spine $5 \mathrm{cts}$

1 Pkt. LETTUCE, Early Curled Simpson $5 \mathrm{cts}$

1 Pkt. LETTUCE, Big Boston Cabbage 5 cts

1 Pkt. MUSKMELON, Osage 5 cts

1 Pkt. WATERMELON, Kleckley Sweet $5 \mathrm{cts}$

1 Pkt. ONION, Ohio Yellow Globe Danvers 5 cts

1 Pkt. PARSNIP, Large Sugar $5 \mathrm{cts}$

1 Pkt. PARSLEY, Moss Curled

$1 / 4$ lb. PEAS, First in Market

1 Pkt. PEPPER, New Royal King

1 Pkt. PUMPKIN, Small Sugar Pie

1 Pkt. RADISH, Earliest Scarlet Globe

1 Pkt. RADISH, Long White Icicle

1 Pkt. SQUASH, Genuine Hubbard

1 Pkt. TOMATO, Spark's Earliana

$5 \mathrm{cts}$

$10 \mathrm{cts}$

5 cts

5 cts

5 cts

$5 \mathrm{cts}$

Pkt. TURNIP, Purple Top White Globe $5 \mathrm{cts}$

\section{No. 44. Best Selling Vegetables. Postpaid \$1.00}

A collection would make a neat gift to some gardening friend.

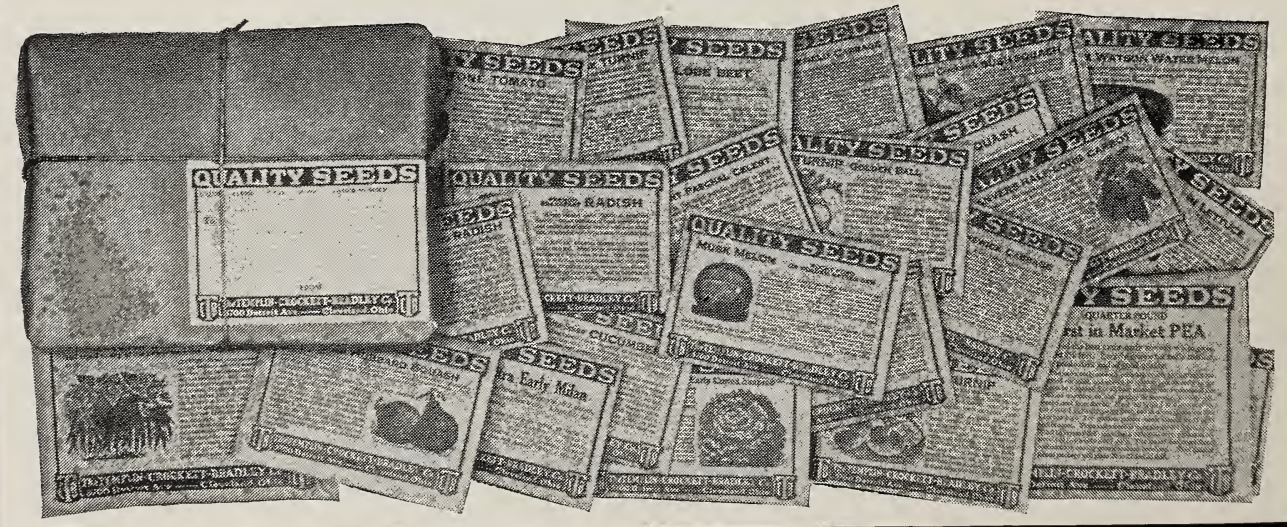




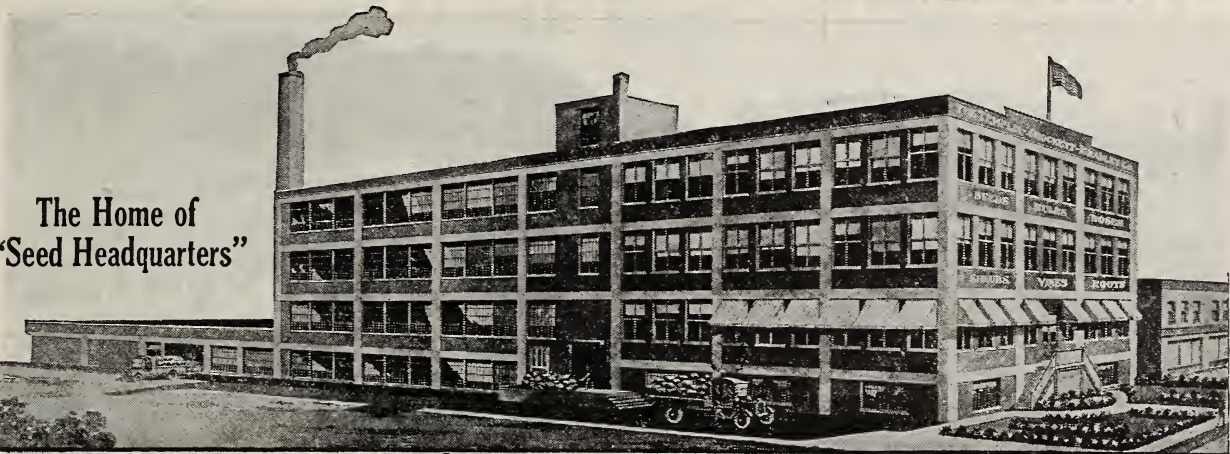

\section{YOUR GARDEN FOR 1923}

Right in your own home, with the help of your family and this catalog, is the ideal place for you to select the seeds, bulbs and shrubs for your garden. For this reason, we employ no agents, yet this catalog will bring our goods as near to you as your own mailbox.

Here are just a few of the real advantages to you in buying from this catalog.

\section{All Prices Include Delivery to cost you with no extras for things are going express or freight, don't you? That is why our customers like to buy from us. Every, price includes delivery.}

\section{No Middleman's Profit When you buy, you like to know that nobody else gets don't you? Our prices are not high enough to give any middleman one cent on your order. Our customers like this policy of rock-bottom prices.}

\section{When Do We Deliver? Seeds will be shipped a few days after your order be shipped as soon as U. S. Weather Reports (which wo receive each plant where you live. This class of stock is packed to keep for a week or more and even if it is little too cold or wet to plant when the goods arrive, instructions, to guide you in keeping them until planting time, will be sent.}

How to Order Just three things to remember. First, use the order blank. It is enclosed envelope is addressed, ready for use. Second, be sure to write your name and address on the order. You would be surprised how many people forget to do this each year. Third, in paying for your goods, use a postal or express money order if at all possible. If you must send cash, be sure to register the envelope. Any one of these three ways you will have a receipt and by using our printed return envelope, you are insured against the order going astray.

When to Order This catalog is sent to you at just this time because we believe it is If we have figured this wrong, we ask you to kindly do it now anyhow and we know you will be glad to have the matter settled.

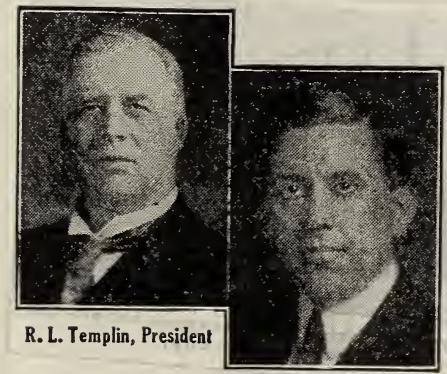

Yours for a successful garden in 1923,

The Templin-Crockett-Bradley Company "Seed Headquarters" 5700 Detroit Ave., Cleveland, Ohio

\section{OUR GUARANTEE}

We guarantee you satisfaction or the return of the money you paid us for any unsatisfactory item.

Reference: The United Banking \& Savings Co., 2000 W. 25th St., Cleveland, Ohio 


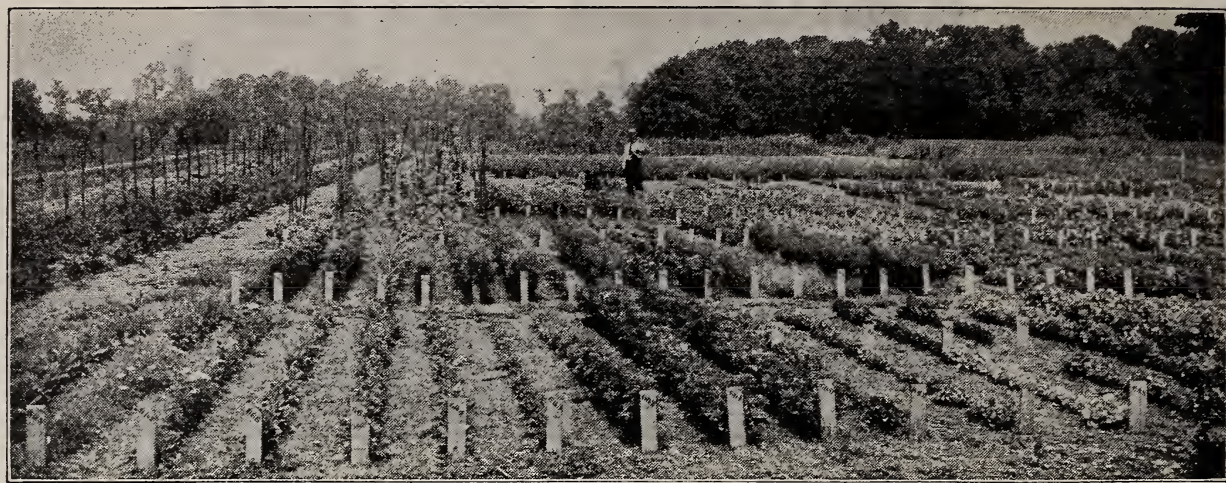

A Partial View of Our Trial Grounds

\section{Proof of Quality}

The outward appearance of seed is seldom an indication of quality. You as buyer must place confidence in us as seedsmen. To merit this, we are very careful that our seeds are of the highest possible quality.

We know which growers produce the best seeds of the various kinds. Our contracts with these producers are made one and two years in advance so that we may be more certain of our supply.

To be sure of germination, we test each lot of seeds in our laboratory, immediately rejecting any seeds which do not come up to the standard we set. At our trial grounds, shown above, we made more than one thousand type tests in 1922.

In addition to proving that our seeds come up to catalog descriptions, we also try out new varieties, before we ask you to buy them. Many of our growers conduct even more extensive trial grounds which we visit for the purpose of study.

So you see, we strive continually to earn for our seeds the name we have given the $m$, "Quality Seeds."

Will you test their quality this year?

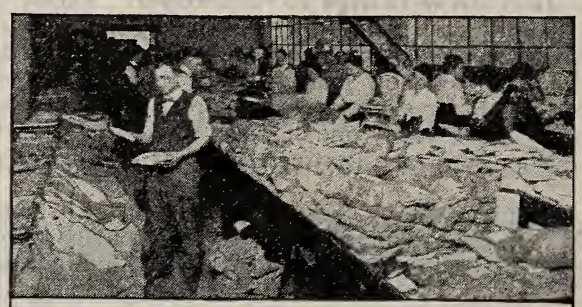

U. S. Postal clerks, right in our own building, cancel stamps and route packages direct to trains.

\section{Proof of Service}

When you realize that we receive an average of 7,000 individual orders per day in the rush season, you can see why we must be prepared to give unusual service, lest we become swamped with the steady stream of orders.

First, and most important, we have an organization of carefully trained men and women. Second, farms, buildings, equipment and shipping facilities for producing and handling the the goods we offer to you for your garden.

In our packeting department we use eight automatic machines, each of which fills, seals and counts 30,000 packets per day. This equipment makes possible, sales of nearly $15,000,000$ packets of seed annually.

The Post Office Departiment keeps clerks in our mailing department to cancel stamps and route packages direct to mail trains, so that the four to five tons of parcel post packages which leave our building daily will not be delayed. This is service.

An hour in our busy plant would show you how we are trying to give intelligent service to our customers.

Will you try us for service this year?
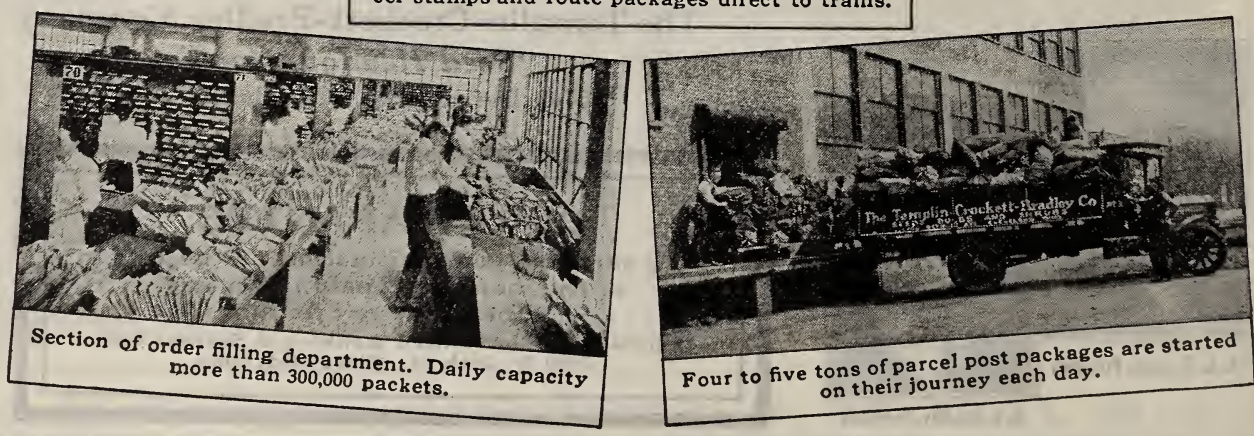
Four to five tons of parcel post packages 


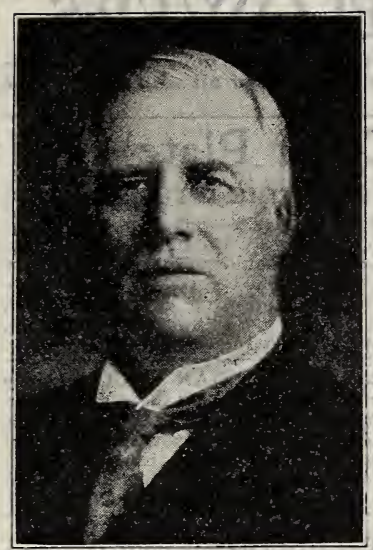

R. L. TEMPLIN

\section{Come Back to This Page Last}

In telling you these things on this page last instead of first, I do it because I do not want anything but the quality of our goods (and the guarantee back of the quality), to influence you in sending in your order. And we have always been fussy about quality because we are close enough to our customers to know what they must have if they are to succeed in their gardening.

Just as an example of this being "fussy," take the case of our Red Giant Carrot on page six. When one of our big French Growers first offered this variety to us, his claims seemed too strong, though we had always found him conservative and reliable about everything else. To test it, we sent free samples to several thousand of our customers and asked them to try the seed and report results. When fall came, the carrots and reports came in from all parts of the United States and they proved to be even larger than our grower had claimed. And they had the additional advantage of excellent flavor, too, which is a most desirable combination. So, you see, we watch for quality.

Now, what I started out to tell you, was about some of the things which have happened in the 47 years that I have been in this business and how they have influenced our present methods of doing business. From the time I was a small boy, my Father conducted a nursery and small greenhouse. I know now, that I stumbled onto the thing I like to do better than anything else in business, the day that I convinced my Father that we could serve our nursery and plant customers better if we could also offer the flower seeds which were then in general demand. So we sent to Ehrfurt, Germany (about the only place where flower seeds were then produced), and obtained a small assortment. We then printed about 1,000 little folders, describing the varieties and handed and mailed them to our customers, neighbors and friends.

Can you imagine the happiness when the first little lot of orders came in? I remember very well how I took the orders home each night after work and in the evening my wife and I would cut packets out of paper, fold them into shape, write the names of the varieties by hand, apply the paste, put in the right quantity of seed and then address the little packages to go by mail or to be called for by customers the next morning.

Is it any wonder that I took a real personal interest in the gardens of those customers? I tell you I was pretty proud when the County Fair came around, to see prizes awarded for the flowers grown from our seeds. I saw that my work was something more than just work. I was playing a small part in the lives of every one of those families who bought from us.

During all the years from 1876 to 1906, when I came to Cleveland, I was studying the needs of our customers and what I learned gave me the courage to start out here in a different way from anything ever tried before. And it is here that you can see the influence of those early years in the growth of The Templin-Crockett-Bradley Co., from a mere idea into what a lot of people are pleased to call their "SEED HEADQUARTERS."

First, we can best serve the greatest number of people by offering only those items which most everybody demands instead of trying to sell every kind of seeds we could obtain. This enables us to have all seeds grown for us by experts and in large enough quantities to obtain the lowest possible prices. That is why the number of kinds we offer you is limited to just the best of each class.

Second, there are two classes of people who buy seeds. The one which knows all about gardening and the other that hesitates to have a garden for fear they do not know just how. And the first of these being by far the larger class, we have made the catalog compact, the descriptions brief, so that it is easy to find what you want. But we have not neglected the people who want information as well as seeds. Brief cultural instructions appear in the catalog, definite instructions on each packet and a 64 page book, full of gardening information, "BETTER GARDENS," is sent free with each order for more than $\$ 2.00$ worth of goods or for 25 cents with smaller orders.

Third, the greatest number of people can be reached and the largest service can be rendered by making the catalog of moderate size and expense. Otherwise, we would be catering to the needs of only a few and the prices all along the line would have to be much higher than they are now.

Fourth, because you must buy your seeds on faith, we must be willing to give an absolute guarantee of satisfaction or money back. I have often been asked by friends if I was not afraid that customers would take an unfair advantage of this guarantee. My answer has been "NO," because our customers have been fair to us in return for our fair treatment of them.

Now just remember this: I will be as much interested in your success this year as I was in the success of my customers back in the seventies and eighties, when our business was very small. So, if you have unusual results, I would be glad to have you write us about them. In case you should be lucky enough to get a good picture of such results, send it along so that we can share in your pleasure, too.

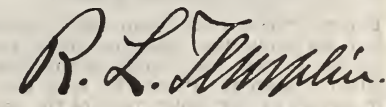

President. 


\section{RARE AND BEAUTIFUL FLOWERS}

Out of thousands of varieties, we have selected a few for these two pages that we feel deserve your special attention. Each is a leader in its class and each will help to make your garden the admiration of all who see it. For exhibitions and flower shows these kinds will be sure prizewinners.

\section{Our Front Cover Collection (See Color Plate)}

1 Aster, Heart of France Opening red as Heart of France retains its remarkable beauty to the very end. The petals appear changeable showing now a glow startlingly beautiful in any light, natural or artificial.

The flowers are large-fully double, opening with the midseason varieties. The plants grow robustly with many branches and long stems. Heart of France will always live close to the hearts of lovers of beautiful flowers. It is by far the finest introduction for many years. Pkt. 10c, 3 pkts. 25c, $1 / 8$ oz. 30c.

3 Cosmos, Double and Crested thise of Cosmos is unique and exceedingly pretty. The flowers are of large size, with fully double centers and an outer row or crest of broad ray petals. They bloom from September to frost.
About fifty per cent will produce double flowers. Pkt. 15c, 2 pkts. 25 c.

6 Scabiosa, Azure Fairy Azure Fairy is as garden as the beautiful blue sky for which it is named.
Dainty as a fairy this lovely azure or lavender blue flower Dainty as a fairy this lovely azure or lavender blue flower bountifully of long stemmed blooms all late summer and fall 2 Calendula, California Orange Among and acres of Calendulas and other flowers, this California Orange is first to attract the eye. Its distinctive orange cast and general growth simply shoulder other varieties out of attention for the time being. The coloring is wonderfulbright as a polished orange a glowing cadmium shade, while the flowers are great big fellows with tall stems on robust, continuous blooming plants. Pkt. 10c, $1 / 2$ oz. 25c.

4 California Poppy PERSIAN RUG MIXTURE. Like a bit of the rich shades of gold, copper red, bronze, claret, scarlet, royal purple and crimson. Each flower is like a tiny silken flag, nodding to every breeze. Plant a good sized bed of these to produce the Persian rug effect. Pkt. 10c, $1 / 4$ oz. 25c.

5 Petunia, Blue Balcony Queen $\underset{\text { type of }}{\text { A new }}$ Petunias of half-trailing habit, fine for porch boxes, hanging baskets, and urns on the lawn, also for bedding. Balcony Queen created a sensation at our trial grounds. You cannot help but gasp with wonder at the rich flowers robed in midnight blue with their blotches of white ermine deep in the throat. The plants bloom-continuously all summer and until
late in the fall. A bed of Balcony Queen Petunias bordered with the white Petunia Snowball is beautiful. Pkt. 15c 2 pkts. 25c.

\section{One packet each of above six varieties. The set for 50 cents.}

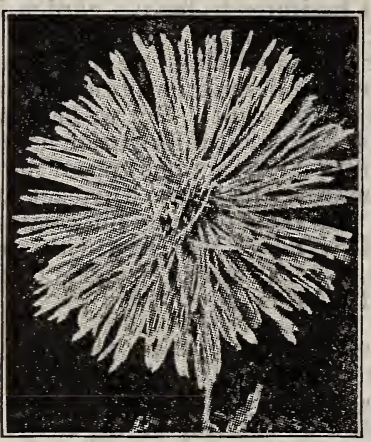

Aster, Unicum White

8 Aster, Unicum White One of the first asters to bloom at our trial grounds last summer was this exquisitely formed pure white flower
with its long ray-like, tightly quilled petals. It resembles a star with the rays of light darting out on all sides. The plants are rather dwarf-nice for low borders and the flowers of large size, 4-5 inches across. Unicum White Aster is a distinct novelty. Pkt. 10c,

9 Blue Lace Flower (DIDISCUS COERULEUS). Queen Anne's Blue Lace Flower is a shade of "heavenly" blue that has decided value in the cut flower bouquet or in the open garden. Blue lace flower is pact mass of dainty individual florets, the whole charming and graceful.

It is not the easiest of annuals to grow, but certainly the pleasure given you
by the flowers pays well for the extra by the flowers pays well for the extra
effort required. Plant the seed early in a cool, rather moist, part of the garden. The plants will burn
hot sun on dry soil. Pkt. 15c.

\section{Centaurea IMPERIALIS} of the Centaurea family which includes the popular Bachelor Buttons. The illustration shows the delicate form of the flowers and how nicely you can arrange them in bouquets. Our strain is a mixture of colors-some snow white, soft as down-others the yellow of the dandelion, still others ranging shades. The flowers are borne on long stems-freely from July until frost. The plant is branching and about $18 \mathrm{in}$. tall. Pkt. 10c, $1 / 4$ oz. 20c.

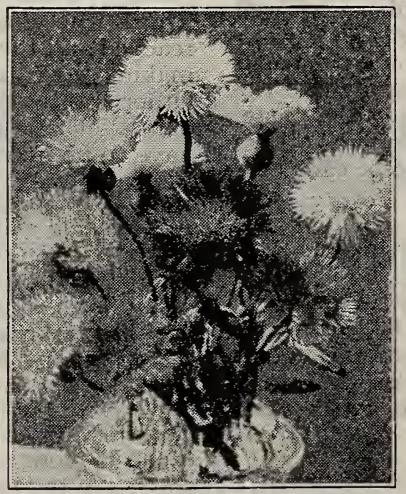

Centaurea, Sweet Sultans

11 African Daisy GOLDEN (DIMORPHOTECA). Rare and showy annuals from South Africa and yet a flower that can be easily grown in your garden in any fairly good soil. The little plants make a fine low border, almost hugging the ground, and spreading out to a width of 8 or 10 inches. Above the dark green foliage shines the large single daisy-like flowers. In color, salmon orange, glistening in the sun like molten gold. Center black. You frosts. Pkt. 10c, 3 for 25 c.
12 Nasturtium - Tom Pounce The best Nasturtium for porch boxes because of its half trailing habit (vines about 2 feet long), and the fact that it bears all summer an almost unbelievable number of flowers. The flowers are little smaller than the ordinary Nasturtium and in color bright yellows and scarlets. At times you hardly see the foliage because of the wealth of flowers. Imagine how pretty they are in porch or window boxes, hanging baskets or trailing over stumps and rocks. Pkt. 10c, oz. 20c.

13 Lobelia, Crystal Palace An improved very compact and dwarf strain and the best blue flowered plant for carpet bedding, edgings, etc. The little bushes stand 4 to 5 inches high and the a ribbon over the rich green foliage. By sowing the seed early indoors and transplanting out in May you can enjoy the flowers from June to November. This strain makes an excellent pot plant also Pkt. 10c, $1 / 8$ oz. 30c.

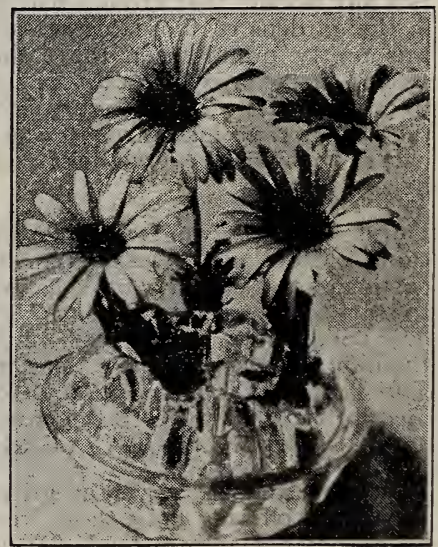

African Daisies (Black and Gold) 


\section{FOR YOUR GARDEN}

Plant plenty of flowers this season. Plant them for your own pleasure and for your friends who perhaps are not fortunate enough to have garden plots of their own. What is more appreciated than the gift of flowers of your own raising? Even a few minutes in your garden every day watching the new beauties unfold will convince you that there is inspiration there and rest from the work of the day.

14 Buttercup or Santa Barbara Poppy (Hunnemannia). If you imagine great Buttercups growing 18 inches high over bushy plants with attractive foliage, you will have some conception of the beauty of this flower. The illustration shows the poppy-like form-and this is the only poppy suitable for cutting.

You can cut these and have them in water for five days to a week, and the buttercup yellow flowers are certainly capable of pretty arrangement. Sure to succeed in any fair garden soil coming in to bloom in July and continuing until fall frosts. An exceedingly pretty flower in the garden or in bouquet. Pkt. 10c, $1 / 4$ oz. 25c.

15 Petunia, Giants of California You will have to see these marvelous size and beauty. Averaging 3 to 4 inches across; the flowers are frilled and lacy embracing dozens of color tones and shades. Frequently visitors to our gardens remark, "I didn't know such petunias existed." Whether you plant them in a big bed, a border or in porch and window boxes, there is surprise and delight in store for you. Pkt. $15 \mathrm{c}, 2$ for $25 \mathrm{c}$.

\section{Poppy, American Flag} The name American Flag always attracts interest and this poppy in no way disappoints. The great big balls stand about 2 feet highoften 6 inches in diameter, of purest white with the tips of the petals dipped in scarlet. A row or a clump of American Flag Poppies will be a glorious and gorgeous sight in your garden. Pkt. 10c, $1 / 4$ oz. 20c.

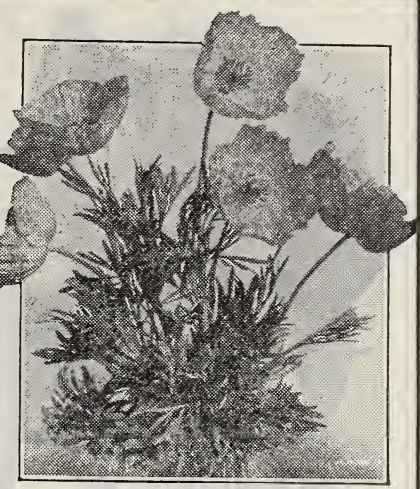

Buttercup or Santa Barbara Poppy

\section{Stella}

(Miniature Sunflower) The best of the Miniature sunflowers with its wealth of golden black-eyed flowers. The plants grow $21 / 2$ to 3 feet tall, upright, branching, excellent for a semi-tall border or clump. The flowers are $33 / 4$ inches across, single, deep golden yellow, contrasting richly with the brownish
black center. An annual, that from seed started in the spring, will bloom July to October. The flowers with their long stems can be arranged for beautiful effect in a vase. Pkt. 10c, $1 / 4$ oz. 20c.

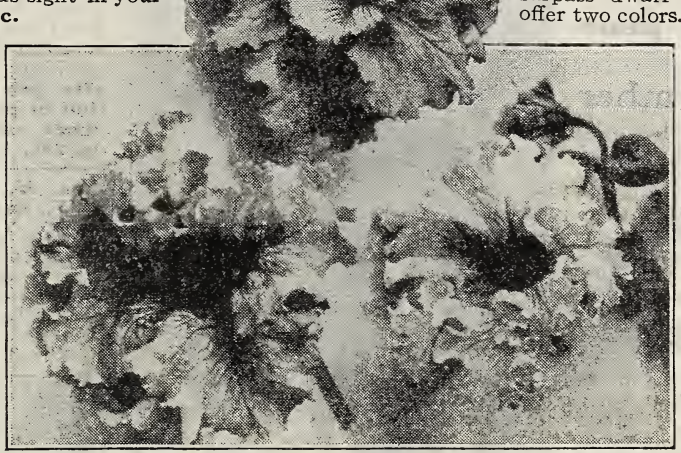

Petunia Giants of California
Two Good Phloxes The dwarf or Nana Compacta Phloxes are not new-but they certainly are deserving of almost universal planting. The plants grow 6 to 8 inches tall on ordinary soil and from seeds started in the open ground blooms all summer. The foliage is practically hidden by the great wealth of bloom. Nothing can surpass dwarf Phlox for a border. We offer two colors. Buy a packet of each.

\section{SOME VERY FINE NEW ZINNIAS}

21 Giant Novelty Mixture This mixture will allow you to enjoy the three latest introductions in Zinnia in various bright colors. The Dahlia flowered type with immense dahlia-like bloom often 4 inches and even more in diameter; the Cactus type with its artistic long quilled petals, and the Picotee Zinnias. This last type has distinctively colored blooms, the petal tips stained a different shade than the rest of the

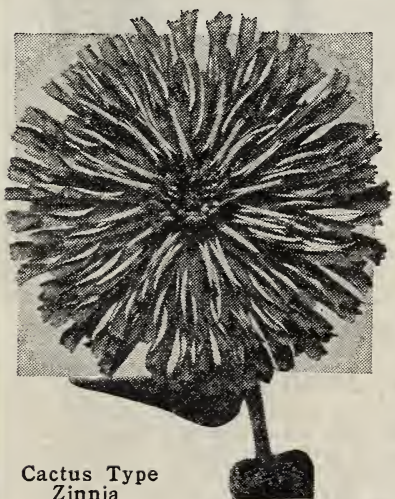
Zinnia

In Our Giant Novelty Mixture flower. The effect is most pleasing. If you want the best there is in Zinnias, try pkts. for 25c.

\section{Red Riding Hood}

This little gem grows but a foot high; of compact form and covered the entire season with little button-like, intense scarlet, very double flowers not over an inch across as a border it is highly effective. Pkt. 10c, $1 / 4$ oz. 25 c.

\section{Star Zinnias}

The new Mexican Hybrids, in colors distinct from all other Zinnias. The colors are mostly mahogany reds, browns and golden yellow in many delightful combinations--some star shaped, some round like a ball. The plants are compact, bushy, about a foot and a half high, the same across, fine for hedgings and covered with flowers all summer and fall. Pkt. 10c.

18 Fireball ${ }_{\text {ribbon }}^{\text {Forms a }}$. nches wide of brilliant scarlet 19 Snowball $P$ u $r$ e always good with other colors. Pkt. 10c, $1 / 8$ oz. 40c.

20 Heavenly Blue A New Morning Glory I PO M E A . A very rapid climber with clusters of imVery beautiful and always attracts attention. Early and onstant bloomer. The seed of this queenly flower comes from faraway Italy, and it is as yet grown in only limited quantity. Pkt. 10c.

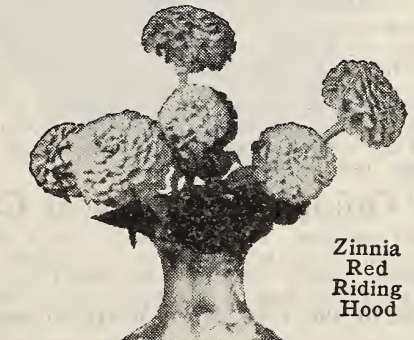




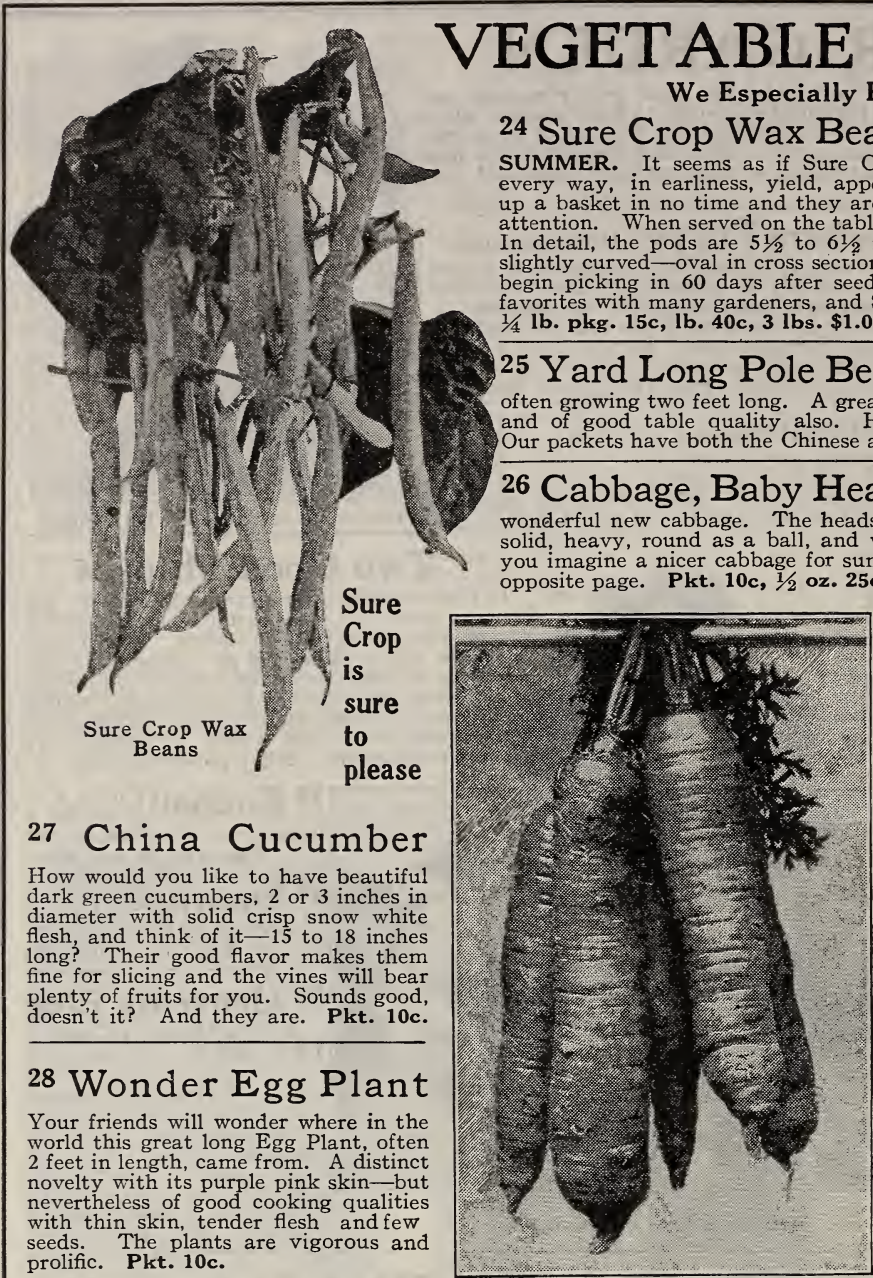

prolific. Pkt. 10c.

\section{Early Mayflower Sweet Corn}

THE EARLIEST OF ALL WHITE REAL SWEET VARIETIES.

How would you like to be the first one to have sweet corn on the table before anyone else in your neighborhood? You can if you plant Early Mayflower-the earliest of all white true sweet corns, excepting none. The ears are surprisingly large for an early variety, averaging ten rows of the tender deliciously sweet kernels-a nice table size. The ears are about 7 inches long. A money maker for the gardener who wants to get the early high prices. We have the introducers pure strain. Make several plantings of sweet corn to always have tender ears. $1 / 4 \mathbf{l b}$. pkg. 15 c, lb. 50 c, 3 lbs. $\$ 1.25$.

31 Golden Giant Sweet Corn This valuable Golden Sweet Corn and earliness. It has attracted much attention and was in great demand last spring. It is a cross between Golden Bantam and Howling Mob, producing heavy stalks, usually carrying two large 12 to 14 rowed ears. The heaviest yielding $12 c, 1 b .40 c, 3$ lbs. $\$ 1.00$. Write for prices on larger quantities.

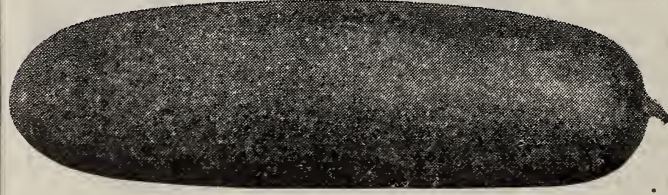

A Fine Slicer-Irish Queen Cucumber
NOVELTIES

OUTYIELDED ALL OTHER WAX

BEANS AT OUR TRIALS LAST earance and quality. The big pods fill handsome enough to attract anybody's them delicious and tender. and a beautiful clear yellow. You can ure Crop is easily the best of that class.

An interesting novelty from the country. Long, slim, round pods always attracts attention and French varieties. Pkt. 5c.

Every garden, no matter how small,
has room for a few plants of this only 5 or 6 inches in diameter, but mer and fall salads? See illustration on 29 Carrot, Red Giant Those who have tried Red Giant tell of the enormous size it grows on mellow soil, often weighing 3 or 4 pounds each; also of the tender flesh which cooks up without a hard, stringy core. In a nutshell, the facts are: Red Giant is actually a giant in sizeis of excellent quality to eat, and of good appearance. Red Giant will give you more edible carrots per foot or per acre occupied than any other existing variety. Pkt. 10c, oz. 25c, $1 / 4$ lb. 60 c, lb. $\$ 2.00$.

Mrs. H. N. Miller, of Ebenezer, N. Y., writes as follows:

"I boiled some of the new Red Giant French Carrots for dinner and I must tell you they are delicious. I certainly shall recommend them to all my friends and neighbors. Five of them weigh 0 pounds. I have always found your seeds and service satisfactory."

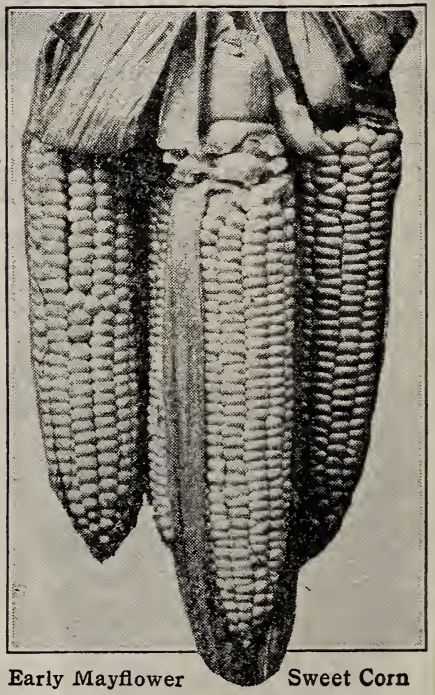

32 Cucumber, Irish Queen $\underset{\text { is dis istinct }}{\text { This }}$ from others, in that it is almost perfectly smooth, free from ridges or spines. The color is deep glossy green, so attractive for the home garden or market. Flesh crisp, sparkling and solid, an excellent slicer. The vines produce abundantly of slicers very uniform in size and shape. Pkt. 5c, oz. 15c, 1/4 lb. 45c, lb. $\$ 1.50$. 


\section{EXTRA GOOD VARIETIES}

\section{To Make Your Garden Profitable}

33 Muskmelon Golden Hearts $\begin{gathered}\text { Here is a melon to make your mouth } \\ \text { water, the deep golden salmon flesh is }\end{gathered}$ so sweet. The melon is medium small, the size in much demand for the fancy hotel trade, averaging 5-6 inches in diameter, yet heavy because of the thick flesh and small seed cavity. It ripens right down to the rind-so ycu can eat almost the whole melon. Often there will be as many as twelve melons to the vine, and they run remarkably uniform in size, shape and quality. Fruit ribbed and protected with a heavy netting. Ready to eat about a week before select early Osage. It is easy to grow good melons at home. No. 42 , the booklet, "Better Gardens," tells how. We suggest that you get

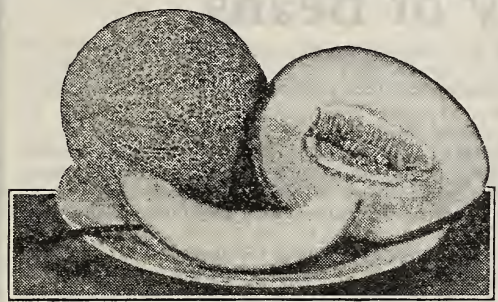

Delicious Golden Hearts Muskmelon 25c, pkt. 15c, oz. 25c, $1 / 4$ lb. 75c.

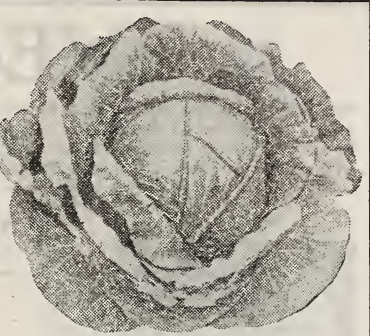

Babyhead Cabbage 34 Chinese Cooking Watermelon The Chinese are ing tasty dishes and they like to take the fruits before they are ripe, cut into thin slices, hang in the sun to dry, pickle the slices in vinegar or put down in syrup or brine. It is said that the fruits will keep fresh and green well into the spring. Grow just as you would ordinary watermelons. Pkt. 10c.

36 Watermelon, Irish Gray On a warm summer day a big slice of Irish Gray is a treat fit for a king The bright red flesh so deliciously sweet and tender surely does hit the spot. Some like it to eat better than any other watermelon. The melon is distinct in appearance, long as shown in the illustration, but solid gray green in color. The rind is thin but so tough that it stands shipping and handling well. Altogether a most profitable melon to grow because of its quality, season (earlier than Tom Watson), and the fact that it yields more marketable melons per acre than any other variety. Pkt. 10c, oz. 20c, $1 / 4$ lb. 55c.

\section{Peter Pan Pea}

Largest Podded Dwarf

Peter Pan leads all the dwarf peas in total yield - size of pod and quality. Compared with a good strain of Notts Excelsior, Peter Pan gave fifty-five per cent more and larger pods. Under ordinary conditions, in seven weeks after the vote them the sweetest peas you ever put in your mouth.

The vines are sturdy and healthy, 15 to 18 inches tall, requiring no support. The pods are very broad, dark green, and average $31 / 2$ inches long. Each pod contains 6 to 8 of the large delicious peas. Peter Pan should be in every garden. $1 / 4$ lb. $15 \mathrm{c}, 1 \mathrm{lb}$. $45 \mathrm{c}, 3 \mathrm{lbs}$. $\$ 1.10$.

\section{Tomato-Gulf State Market}

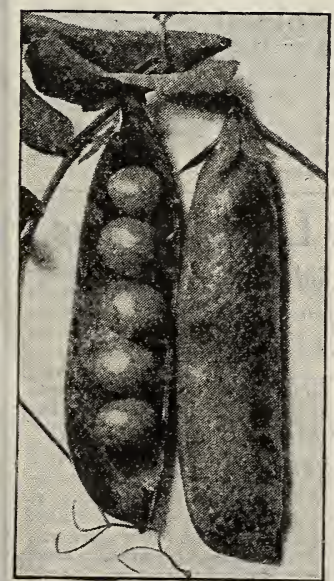

Peter Pan Pea

The heaviest yielding of all tomatoesbest and eariliest of the purple pink varieties. That is the result obtained on our tria grounds the past year where we tested all of the leading varieties. Gulf State Market gave qu ntities of clusters of big, firm tomatoes. Plant Gulf State not only because it fills up the baskets so quickly, but because each fruit is so firm, almost true globe shaped-ripened uniformly and free from cracks or blemishes around the stem-end even in a poor season. The vines are so vigorous the plants seldom blight. Certainly if you want a purplish pink tomato, Gulf State Market is the tomato for you to plant. Pkt. 20c, $1 / 4$ oz. 65c, oz. $\$ 2.00$.

40 Tomato-The Norton One of the wilt-resistant varieties recomyield and in form and color of fruit, is very similar to the Improved Stone Tomato, but it has the added value of being as nearly blight and wilt resistant as science can produce. The Norton makes possible the production of big profitable tomato crops in sections where blight and wilt have affected the crops badly before. A fine, smooth, fancy tomato. Pkt. $10 \mathrm{c}, 1 / 2$ oz. 30c, oz. 50c.

41 Mammoth Shogoin Turnip This new Turnip comes from Japan, measuring 8 and more inches in diameter and like a top in shape. The Japanese, who are famed for their epicurean tastes, consider Shogoin the finest turnip their country has introduced. Color white, flesh very solid, crisp and tender, in flavor mild and sweet. Grow Mammoth Shogoin to exhibit at the fairs. Pkt. 10c, oz. 25c, $1 / 4$ lb. 60c, lb. $\$ 1 . .50$ 


\section{VEGETABLE SEEDS}

We have always made it a matter of house policy to list only a few of the most worthy varieties which are in the greatest general demand. These are all certain to give uniform satisfaction. The wisdom of this action has been proven beyond a doubt as we are able not only to greatly reduce the cost of catalogs but also to sell larger quantities of each variety listed, at less expense. This saving is passed on to you ingreater values for your money.

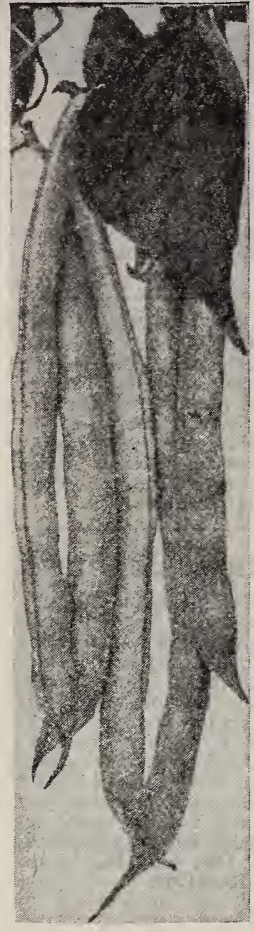

Burpee's Stringless Green Pod Beans

46 Asparagous (Columbian Mammoth White). By all means grow a row or two of tender, juicy, white stalks. Pkt. 5c, oz. 15c. You can save time by planting roots listed on page 40 .

\section{Grow Plenty of Beans}

They are easy to grow- not bothered by insects. By growing your own, you can have them always tender without bothersome strings. You always get so much back for your efforts. They give a large yield from a small space- even a 10 foot row giving several nice pickings. Beans provide many delicious and wholesome dishes.

To Have Beans at Their Best-Make several successive plantings. As most varieties are ready to pick in 45 to 50 days you can keep planting just as long as there is that much time left before frost. Another good idea is to plant an early and late variety at the same time, for instance, Burpee's Stringless and 1000 to 1 Green Pods and Webber and Hodson Wax Pods. Pick beans while the pods are young and tender. Steady picking induces greater production. Do not jerk the pods off but snip them off with scissors, knife or finger nail.

CULTURE-Detailed directions on each package and in booklet "Better Gardens."

EACH $1 / 4$ LB. PACKET OF BEANS WILL PLANT 40 TO 50 FEET OF ROW.

\section{Dwarf Green Pods}

47 Burpee's Stringless Green-Pod (Round The most popular of the round podded varieties. Early, very productive- pods tender, fleshy and free from strings. Whether for home or market, we know of no variety combining more good qualities. Ready to pick in 50 to 55 days from planting. $1 / 4 \mathbf{l b}$. pkg. 12c, lb. 35c, 3 lbs. $\$ 1.00$.

48 Early Bountiful (Flat Podded). Will yield more in our list. Best of the flat podded stringless varieties, pods $61 / 2$ to 7 inches long, stout, flat and nearly straight, stringless, and of fine quality* color light green. Very early, vigorous, hardy and productive, the pods remaining tender for a long time. $1 / 4 \mathbf{l b}$. pkg. 10c, lb. 30c, 3 lbs. 80c.

49 Giant Stringless Green-Pod ${ }_{A n}^{\text {(Round Pod). }}$ exceedingly productive and very handsome stringless variety. Similar to Burpee's Stringless, but pods a trifle longer, straighter, and a shade lighter green. $1 / 4$ lb. pkg. 10c, lb. 30c, 3 lbs. 80c.

50 Refugee 1000 to 1 (Round Pod). A delicious grained, juicy, round pods Planted at the same time as the early varieties, will give pickings about a week later. $1 / 4 \mathbf{l b}$ loc, ib. $\mathbf{3 0 c}, \mathbf{3} \mathbf{~ l b s} . \mathbf{8 0 c}$.

\section{Dwarf Wax or Butter Beans}

Sure Crop Wax (Oval Round Pod). The best of the black seeded varieties. Wax For full description see No. 24 on page 6.

51 New Webber Wax (Flat Pod). We asked our bean grower to name what

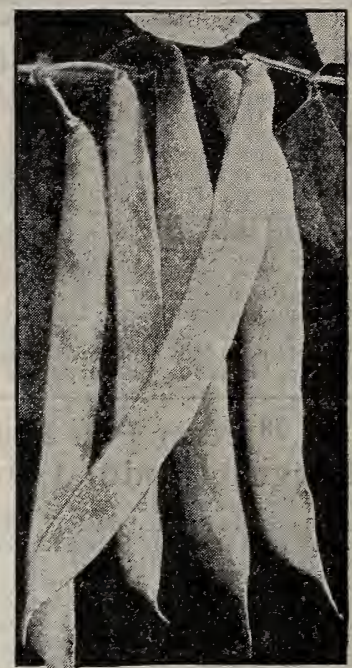

New Webber Wax Beans

"Webber Wax." It is very vigorous, healthy, and wonderfully productive In our experience, Webber is invariably ready to pick before any other wax bean and will yield more than any with the single exception of Sure Crop Wax. Broad, flat, golden yellow, gracefully curved, pods are absolutely free from strings. $1 / 4 \mathrm{lb}$. pkg. 12c, lb. 35c, 3 lbs. 90c.

\section{Improved Golden Wax}

(Flat Pod). Greatly improved over the old style Golden Wax, and it will pay you to plant our strain of this splendid variety. Pods perfectly straight, very broad, flat, but thick through, fleshy and stringless, when picked at the right stage. An early abundant cropp

53 Stringless Refugee Wax (Round Pod). Tender enough to melt in your mouth and absolutely stringless Better in all ways than the old Refugee Wax. Productive and early. Round pods 5 inches long, very fleshy and curved. $1 / 4$ lb. pkg. 12c, lb. 35c, 3 lbs. 90c.

54 Hodson Wax (Flat Pod). A yielder, the plants being loaded with long, straight, handsome creamy-white pods. It is vigorous, hardy, always succeeding. Ready to pick 10 days later than Webber Wax. $1 / 4$ lb. pkg. 12c, lb. 35c, 3 lbs. $\$ 1.00$.

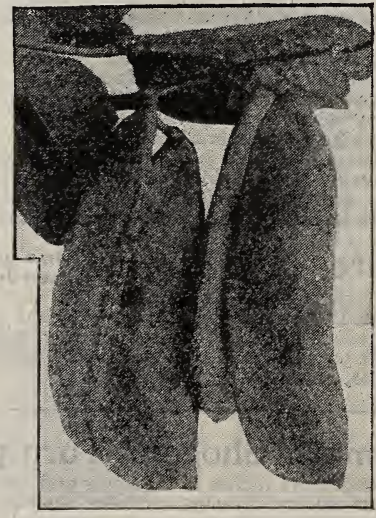

Wonder Bush Lima Beans

\section{White Baking Bean}

55 New Robust The best white ing. Also called "1000 to 1" Field Bean. The dry beans are the same shape and color as the popular Boston Pea Bean, but it has been proved by experiment stations and private trials that New Robust outyields all other white beans. $1 / 4$ lb. pkg. 10c, lb. 25 c, 3 lbs. for 70 c.

\section{Bush Lima Beans} 56 New Wonder The recogard of bush Lima Bean quality - so considered by critical experts. Large, robust, compact, plants; productive. Pods uniformly large, produced in clusters and maturing in midseason. Large flat beans of superior quality. $1 / 4 \mathrm{lb}$. pkg. 15c, lb. $45 c, 3$ lbs. $\$ 1.25$.

57 Henderson's Early earliest of all Lima Beans - by planting it gardeners in even the northernmost States can enjoy Limas from their own gardens. Pods are small but borne so plentifully that the yield is large. Beans of excellent flavor. $1 / 4$ lb. pkg. 12c, lb. 35c, 3 lbs. $\$ 1.00$. 


\section{Pole or Cornhill Beans}

Pole beans bear for a longer season than Dwarfs, each plant giving many more pods. CULTURE-Full directions on each packet and in booklet, "Better Gardens."

58 Kentucky Wonder or Old Homestead. The most useful and satiswonderfully prolific, bearing continually until frosts; pods very long, in clusters. May be planted with corn. $1 / 4$ lb. pkg. 12c, lb. 35c, 3 lbs. $\$ 1.00$.

59 Golden Cluster Wax The best of all the Wax Pod Pole Beans. Pods 6 fleshy and stringless. Shelled beans pure white. $1 / 4.1 \mathbf{b}$. pkg. 15c, lb. $\mathbf{4 0 c}, 3 \mathrm{lbs}$. $\$ \mathbf{1 . 1 0}$. 60 Lazy Wife One of the most popular either for snaps, shell beans (white seed), Long, broad, thick and fleshy, green pod. $1 / 4 \mathrm{lb}$. pkg. 12c, lb. 35c, 3 lbs. $\$ 1.00$. 61 Cut Short or Cornhill Fine for planting in corn. Pods fleshy and of wherever grown. Green pod. $1 / 4 \mathrm{lb}$. 12c, lb. $40 \mathrm{c}, 3 \mathrm{lbs}$. $\$ 1.10$.

62 Horticultural or Cranberry (Wren's Egg) $\begin{aligned} & \text { Popular as a } \\ & \text { shelled bean, }\end{aligned}$ either green or dry. Dry seed speckled. $1 / 4$ lb. pkg. 12c, lb. 40c, 3 lbs. $\$ 1.10$.

63 Pole Lima King of the Garden Extensive trials show this to be unsurpassed in yield or quality. The vines produce continually until killed by frost. $1 / 4$ lb. 15c, lb. 40 c, 3 lbs. $\$ 1.10$.

\section{Tender Table Beets}

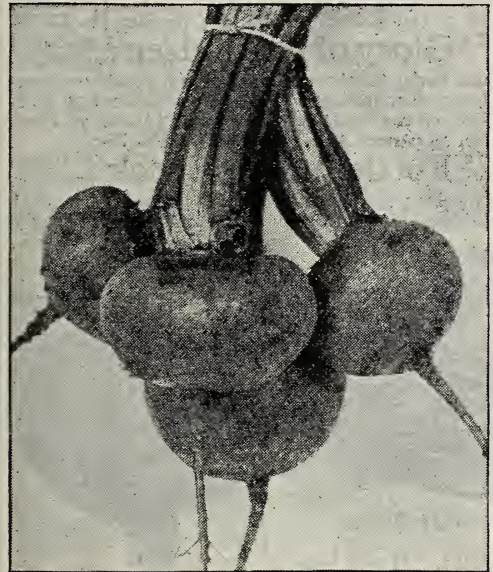

Crosby's Egyptian Beets

\section{Mangel Beets}

FOR POULTRY AND STOCK-Stock and poultry raisers have found that it pays to grow mangels for winter feed. Mangels increase the flow and better the quality of milk, help to keep cows in good healthy condition, besides saving tons of fodder. Often yield 30-40 tons per acre; harvesting easily at small cost. It will pay everyone who keeps even one cow to grow a patch of mangels. Hang a root up where the poultry can peck at it also. 68 Mammoth Long Red $\mathrm{T}$ h e yielding of all mangels-often $21 / 2$ feet long and very heavy. Grows half out of ground-easy to harvest. Oz. 10c, $1 / 4$ lb. 25c, lb. 60c.

69 Golden Giant Best of the yellow contain more sugar, so richer feed and said to varieties. Oz. 10c, $1 / 4$ lb. 25c, lb. 60c.

\section{Lucullus Swiss Chard}

70 SPINACH BEET. No other vegetable will produce more nutritious greens from a small space than Swiss Chard. It grows rapidly, forming broad, flat, beautiful wax-like stems which are delicious when cooked and served like spinach or asparagus. Pkt. 5c, large ounce pkg. 10c.

\section{Perfection Brussels Sprouts}

71 Belongs to the cabbage family. Small heads of delicious quality are abundantly produced along the stem, the plants growing about 2 feet high. Cultivate same as late cabbage. Produces its tender little heads from October to December in the North, and throughout the winter in the South. Pkt. 10c, 1/2 ounce pkg. 20c.

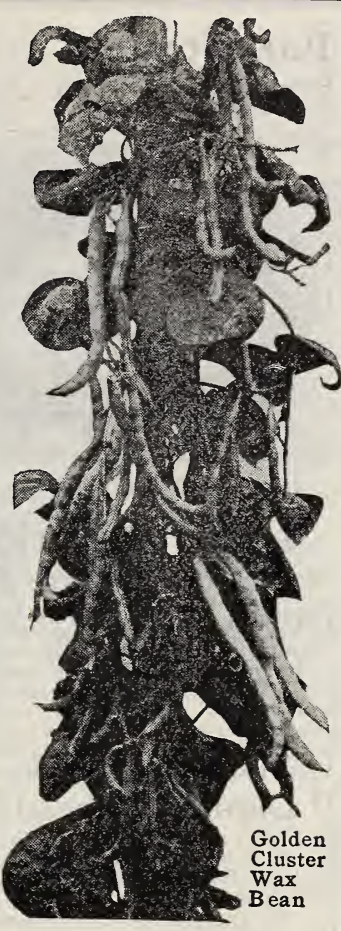

as well. Crosby's Egyptian is best for early planting. Detroit CULTURE-Directions on packets and in booklet "Better Gardens."

64 Crosby's Egyptian The first to produce edible roots. ment on Old Eovptian. Roots slightly flattened, globe shape; skin blood , flesh slightly zoned; tops small. A universal favorite. Pkt. 5c,

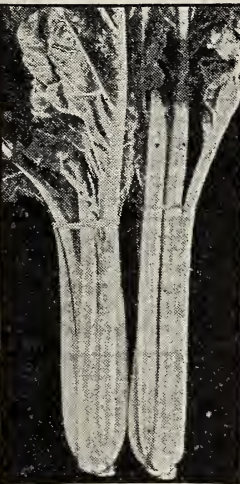

Swiss Chard unched for market, retaining its deep red color no matter how served. A big cropper with small upright tops permitting close planting. The roots are globe shaped. Skin and flesh dark blood red without the white zones. Sweet, tender and delicious. Our seed stock is especially selected to give you roots very uniform in size and appearance. Pkt. 5c, oz. 10c, $1 / 4$ lb. 35c.

66 Crimson Globe We are offering smooth strain that shows few rootlets. Medium size; globe shape. Flesh deep purplered; lightly zoned. Sweet, tender, never stringy when grown under fair conditions. Pkt. 5c, large oz. pkg. 10c, $1 / 4$ lb. 35c.

67 Eclipse Fine for the home garden Eclipse because of its medium small smooth roots and very sweet tender flesh Pkt. 5c, large oz. pkg. 10c, $1 / 4$ lb. 30c.

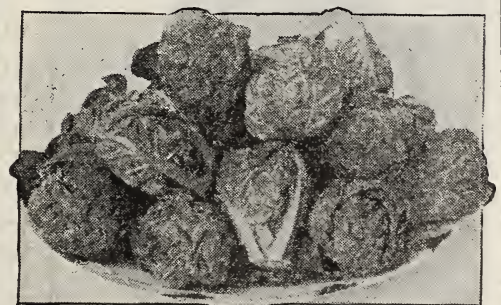

Brussels Sprouts 


\section{Pure Strains}

Surely you want cabbage. A nice head of cabbage doesn't require very much space in your garden, but what a lot of wholesome food it will give you. Creamed cabbage, cabbage salad, cold slaw, hot slaw, or kraut, and chances are you have some

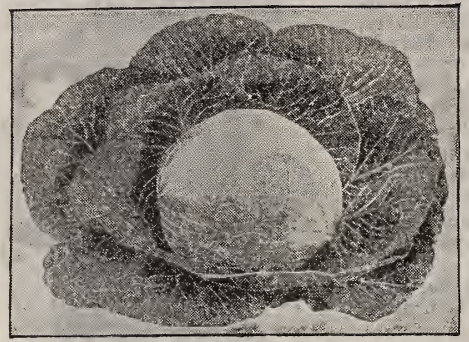

Copenhagen Market

\section{Late Varieties}

76 Premium Late Flat

Dutch Probably more largely Dutch grown than any other late variety, because everybody knows it is alivays reliable. Uniform, large, flatgood keeper. Largely grown to supply kraut factories. Will produce more tons per acre than any other variety. Pkt. 5c, $1 / 2$ oz. pkg. 15c, $1 / 4$ lb. 75 c, lb. $\$ 2.00$. 77 Danish Ballhead The iltion from a photo taken in Denmark is a good representation of the kind of seed we offer. For quality no other winter Cabbage equals and fine grained. Always brings the highest market prices. One of the best keepers, coming out of the pit in March or April fresh and solid. The heads are not as large as the American Drumhead varieties, but very much more solid. Pkt. 10c, $1 / 2$ oz. 20c, oz. 30c, $1 / 4$ lb. 90c, lb. $\$ 2.75$.

78 Burpee's Surehead Uniformly large, heads of drumhead type. A universal favorite for main crop. A good keeper and of finest quality. Pkt. 5c, 1/2 ounce plrg. 15c, oz. $25 \mathrm{c}, 1 / 1 \mathrm{lb}$. $90 \mathrm{c}$, lb. $\$ 2.50$.

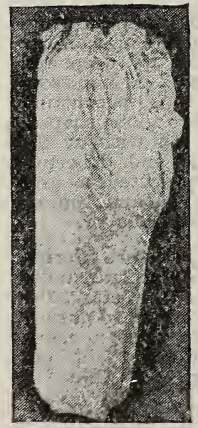

79 Drumhead Savoy

Many consider Savoys the finest quality of all Cabbages. The leaves are finely curled and heads solid. If you have never grown Savoy Cabbage, try it this year. Pkt. 5c, $1 / 2 \mathbf{~ o z . ~ 1 5 c , ~ o z . ~ 2 5 c . ~}$ 80 Red Dutch Pickling The most popular of the red pickling woighing 7 or 8 pounds. A splendid keeper. Popular for slaw and pickling. Pkt. 5c, 1/2 oz. pkg. 15c, oz. 25c.

81 Pe-Tsai (Chinese or Celery Cabbage). A new vegetable from celery. As a salad it rivals the finest lettuce, or cooked like cabbage or spinach it makes splendid greens. For main crop sow the seed last of August, and transplant a foot apart. Pkt. 5c, $1 / 2$ ounce pkg. 15c, oz. 25c.

\section{home use or market.}

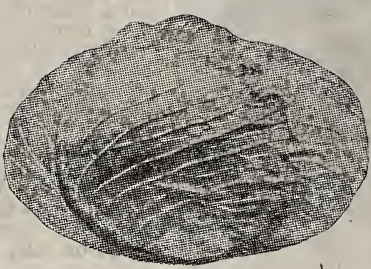

Premium Late Flat Dutch

WHERE THE BEST CABBAGE SEED IS PRODUCED

Denmark. It is generally conceded that the most reliable seed comes from Denmark. We want our patrons to have the best, and therefore handle only Danish grown seed.

73 Copenhagen Market The earliest solid, round head varieties, being only a few days later than Wakefield, but much larger and heavier. Heads average 8 to $10 \mathrm{lbs}$. each. Very commit clo habit, with few outer leaves, which perlarge heads and superior quality have made this new cabbage very profitable. Pkt. 10c, $1 / 2$ oz. pkg. 20c, oz. 30c, $1 / 4$ lb. 90c, lb. $\$ 2.75$ 74 Glory of Enkhuizen A splendid um early variety from Holland, closely resembling Copenhagen Market, and by many considered the best early round head variety. Pkt. 75 Fottler's Brunswick Matures the early and late varieties. Heads large, flat and solid. Valuable as second early and for early winter. Pkt. 5c, $1 / 2$ oz. $15 c, 0 z .25 c, 1 / 41 \mathrm{lb} .75 \mathrm{c}$.

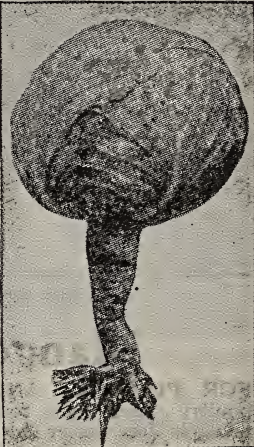

Danish Ballhead

Cabbage Seed is largely grown on Long Island, near Puget Sound, in Holland and in

\section{Cauliflower}

CULTURE-For early crop, Cauliflower should be started in boxes or hotbed and transplanted when large enough. For main crop plant and cultivate same as late cabbage. When the heads begin to form gather the outer leaves and tie together to protect from the hot sun. Cauliflower is one of the most delicious vegetables grown, and by planting our "Quality" Seed in rich, deep, moist soil, the crop is almost as sure as cabbage. If you have not been successful heretofore try again.

82 Early Snowball We believe this to be the very best variety in existThen why should we list other varieties to fine We handle what we believe to be of the very best quality. Grown by one of the best known and most reputable growers of Denmark. We do not hesitate to recommend it, feeling sure that it will please the most critical grower. Pkt. 300 to 400 seeds, $10 \mathrm{c}, 1 / 8$ ounce pkg. $30 \mathrm{c}, 1 / 2$ oz. $\$ 1.00$, ounce $\$ 1.75$.

Snowball Cauliflower 


\section{For Table Use}

Carrots deserve a space in your garden. In fact make several plantings so that you can have some early, midseason and late. Carrots pulled just as soon as sizeable are at their best, tender without any hard core. Earliest Scarlet Horn give dandy little roots in 7 to 8 weeks from planting, while Danvers will be ready in about 10 weeks. Doctors recommend carrots as one of the healthiest vegetables to eat and the family who eats plenty of carrots will like those from their own garden best.

CULTURE-Detailed directions on packets and booklet "Better Gardens."

83 Earliest Scarlet Horn The earliest variety in cultivation. desirable for early garden culture. The tops are very small. The roots are reddish orange and are nearly round when forced quickly in very rich, well prepared soil, but are somewhat longer when grown out-doors. When fully matured the roots are about two to two and one-half inches long, but they should be used before fully grown while young and tender. Also called French Forcing. Pkt. 5c, ounce $15 c, 1 / 4$ lb. 35c, lb. $\$ 1.15$.

84 Oxheart or Guerande. Especially good for shallow or hard soils. blunt point, easily gathered. Finest quality for table use; also desirable for winter poultry food. Oxheart is orten grown for stock feeding, yielding 15 to 20 tons per acre. Pkt. 5c, ounce pkg. 10c, $1 / 4$ lb. $30 c, 1 b . \$ 1.00$.

85 Danvers Half-Long The most Carrot in cultivation. Originated at Danvers, Mass. The roots will average $1 \frac{1}{2}$ to 2 inches in diameter and 5 to 6 inches long, holding their thickness well to the point. More largely grown than any other variety. A favorite with market gardeners for bunching, making a fine appearance. Size, shape, color and sweetness are ideal. A first-class carrot for all soils. Not only desirable for table use, but a heavy yielder and good keeper for feeding stock. Pkt. 5c, ounce $10 \mathrm{c}, 1 / 4 \mathrm{lb} .30 \mathrm{c}, 1 \mathrm{~b}$. $\$ 1.00$.

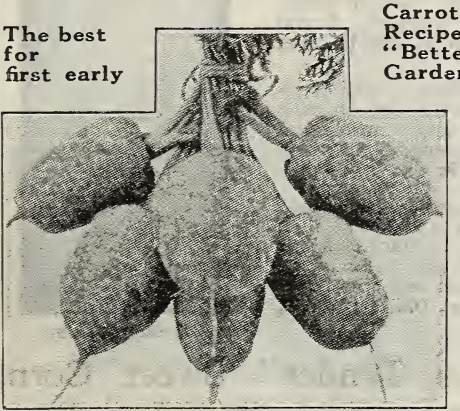

Earliest Scarlet Horn Carrot

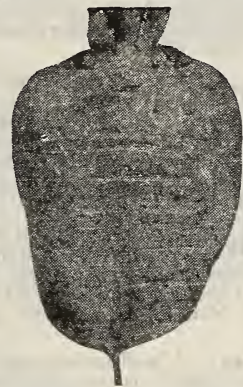

Oxheart Carrot

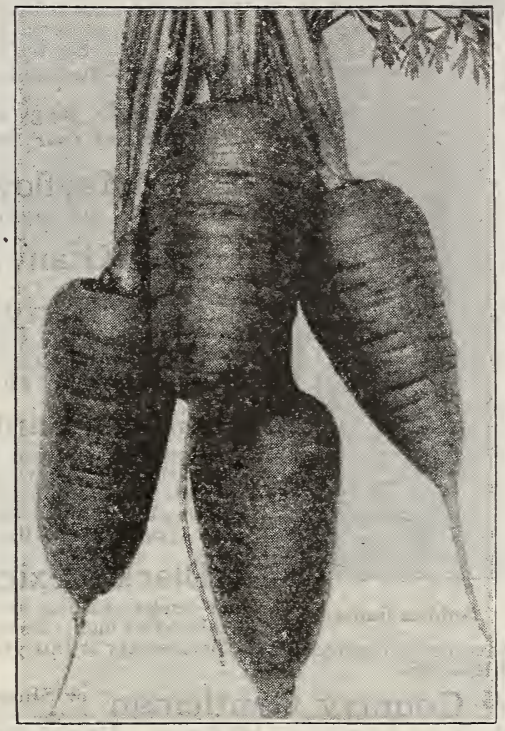

Danvers Half Long Carrot

New Red Giant A wonderful Variety. See No. 29 on page 6. 86 Mastodon Giant White. Best and largest stock Carrot grown. Mastodon Nearly hall its length grows a above ground, making it and stock. Ounce pkt. 10c, $1 / 4$ lb. pkg. 25c, lb. $80 \mathrm{c}$.

Doesn't This Sound Good?
Miss Gertrude Broyle of St. Joseph, Mo., writes: "Your Red Giants
gave me the best carrots I ever raised. They were so large and I learned
to make so many nice dishes. Carrot pie is great, salad we all like and
baked with a piece of smoked ham it is better than chicken."
"One of our leading doctors uses carrots instead of iron to build blood-
so encourage your customers to grow more carrots.".

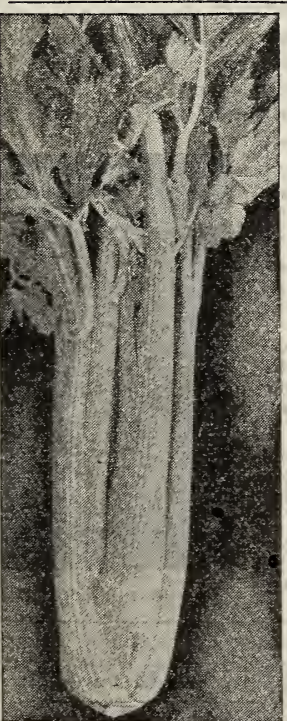

Celery, Easy-Blanching

\section{Celery}

CUL.TURE-Sow seeds in hotbed or cold frame. As soon as the plants are about 3 inches high, transplant to a nicely prepared bed in the border, setting them 4 or 5 inches apart. When about 8 inches high, and fine, stocky plarits, set them out in rows $3 \mathrm{ft}$. a part and cultivate well during summer. Earth up for blanching in autumn, but never hoe or earth up when the foliage is moist or wet. A packet will produce 300 to 400 plants; an ounce 5000 to 6000 plants. 87 New Easy Blanching A new variety of great merit. The yellowish-green foliage. It is very easily blanched, and might be termed a second-early variety. Due to the solidity of the stalks it is a first-rate keeper. The flavor is first class, while the stalks are pure white, heavy and crisp. Pkt. 10c, $1 / 4$ oz. pkg. 15c, ounce 50c.

88 Golden Self-Blanching The best of all early selfdwarf compact growth, with thick, solid, heavily ribbed stalks, which blanch easily to a clear waxen-yellow. More extensively grown for both home and market than any other variety. Pkt. 8c, $1 / 4$ oz. pkg. $15 \mathrm{c}$, oz. $40 \mathrm{c}$.

89 White Plume The earliest and most easily blanched celery lig cultivation, hence its popularity. Foliage An excellent autumn variety. Pkt. 5c., $1 / 4$ ounce 10 c, ounce 30c.

90 Giant Pascal A standard fall and winter variety of vigorand broad. One of the best for winter use, excellent quality for home use, but too tender to stand shipping. Golden yellow heart, and fine nutty flavor. Pkt. 5c, 1/4 ounce pkg. 10c, ounce 30c.

91 Celeriac Turnip-rooted Celery. The large, solid, turnip-like turnips or flavoring soups, etc. For winter and spring use, store same as turnips or beets. Pkt. 5c, $1 / 4$ ounce pkg. 10 c.

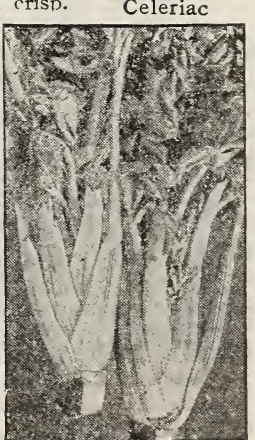

Golden self-Blanching 


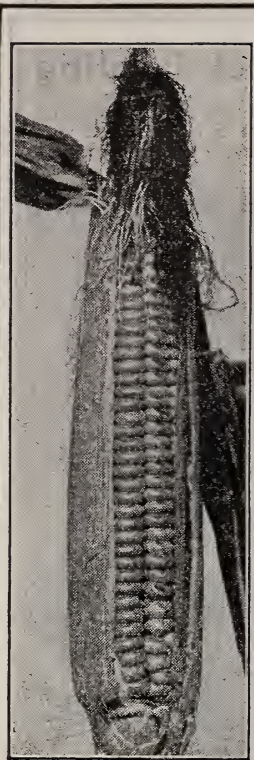

Golden Bantam

\section{Grow Sweet Corn}

DO YOU KNOW WHY HOME GROWN SWEET CORN ALWAYS TASTES BEST Within a few hours after the tender ears are pulled off the stalk they begin to lose their sugar, and they deteriorate rapidly in flavor. You can seldom buy absolutely fresh green corn-so unless you have grown your own you probably do not know how deliciously sweet it can be.

Make several plantings of sweet corn-starting as soon as the soil is warm and frost danger is past, then a few more hills every week or ten days. The early varieties, like Golden Bantam, are ready to eat in about 70 days from planting. It is not difficult to can what you do not immediately use on the table. See the recipes in "Better Gardens."

CULTURE-Instructions on each packet and in booklet, "Better Gardens."

Each 1/4-lb. pkg. of Sweet Corn plants about 150 hills. Remember our Sweet Corn Prices include postage.

Early Mayflower Fine for home garden and profitable for variety, No. 30, page 6 .

Golden Giant ${ }^{\circ}$ a beautiful yellow variety, larger than Golden 92 Extra Early White Cory The earliest and best of all 10 to 12 rowed, 7 to 8 inches long, fairly sweet, tender and white. Stalks about 4 feet high, usually producing two large handsome ears on each stalk. $1 / 4$ lb. pkg. 10c, lb. 25c, 3 lbs. 65 c.

93 Golden Bantam A very early Sweet Corn with golden-yelsweetest and tenderest variety in existence. Probably more extensively grown than any other early variety. A few days later than Cory. Height 4 to 5 feet. Two ears to each stalk. Ears 6 inches long. Eight rows of kernels. Our stock is the best Northern Ohio grown. Sure to please you. $1 / 4 \mathbf{l b}$. pkg. 12c, lb. 30c, 3 lbs. 80c.

94 Black Mexican By many considered the tenderest and sweetand tender turning to est of all. Cooks pure white while young and tender, turning to bluish-black when ripe. Ripens medium early.
Stalks 6 feet high, ears eight inches long with 8 to 10 rows of grains. If you have never planted Black Mexican try it this year. You will be pleased. $1 / 4$ lb. pkg. 12c, lb. 30c, 3 lbs. 75 .

95 Country Gentleman or Shoe-Peg. A well-known variety which is par excelthat there is little room left for cob. Very productive. Market gardeners who supply hotels and high-class restaurants depend on this for main crop. The ears are 6 to 7 inches long, small white cob, with narrow deep grains in irregular rows. $1 / 4 \mathrm{lb}$. pkg. 12c, lb. $30 \mathrm{c}, 3$ lbs. 75c.

96 Stowell's Evergreen The standard main crop variety, much used for the home very been carefully grown and selected to avoid the tendency to a shorter grain and deterioration in the

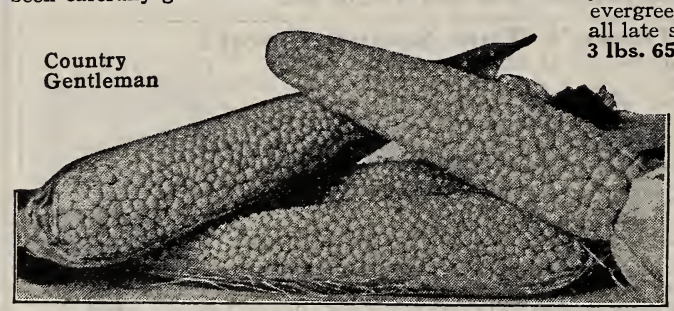
evergreen character of this best known of all late sorts. $1 / 4$ lb. pkg. 10c, 1 lb. 25c, 3 lbs. 65 c.

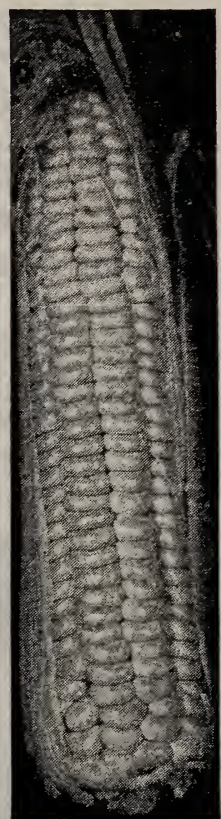

Golden Giant

\section{7 "Always Tender" Sweet Corn} Collection These three varieties follow each other in some of each at the same time you will have sweet corn for your table, always tender and delicious.

Golden Bantam Golden Giant Stowell's Evergreen $1 / 4$ lb. pkt. each of the above three varieties for 30 c.

$1 \mathrm{lb}$. each of the above three varieties for 85c.

Ask for our Always Tender Sweet Corn Collection No. 97.

WHY OUR SWEET CORN SEED GROWS THE BEST CROPS

Because the seed is grown in northern Ohio and Michigan, it produces crops that mature earlier than seed grown in the South or West. Western grown seed looks nice, but the kernels are liable to be "flinty," containing less sugar, and it is later in maturing. Remember this in buying.

\section{Pop Corn}

98 Japanese or Australian Hulless. A dwarf-growing corn, a heavy yielder of attractive the ears, peculiar in form, being nearly as thick as long. The kernels are similar to merit lies in its popping quality, fine flavor and slimmer and pearly white in color, $\mathbf{~} \mathbf{c}, 1 / 4 \mathbf{~ l b}$. pkg. 12c, 1 lb. 30c, 3 lbs. 80c. Popping stock, 5 lbs. 75c.

99 Improved White Rice For years this was considered the "only" Pop Corn, and Our strain is selected to produce more ears per stalk, and will often produce 3 to 4 fine ears. $1 / 4 \mathrm{lb}$. pkg. 10c, 1 lb. 25c, 3 lbs. 65c. Popping stock, 5 lbs. 60c.

100 Queen's Golden Imagine great flaky kernels of Popped Corn nearly an inch across. Queen's Golden will give you that pleasure. The ears are rich golden yellow and are the largest of all pop corns. 1/4 lb. pkg. 10c, lb. 30c, 3 lbs. 75c. Popping stock, 5 lbs. 80 c.

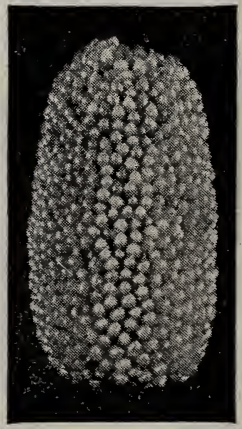

Japanese Hulless

101 These belong to the cabbage family, and are largely grown in the South to use as boiling greens These belong to the cabbage family, and are largely grown in the South to use as boiling greens
during the winter months. Also valuable for furnishing green forage for poultry, as it continues to during the winter months. Also valuable for furnishing green forage for poultry, as it continues to
grow all winter in the South. Freezing does not injure but improves the quality. Pkt.5c, ounce 15c.

Witloof Chicory-French Endive A delicious new salad plant that you should try this year. Chive See 35, page 7. 


\section{Cucumbers}

DO YOU LIKE COOL SLICED CUCUMBERS IN HOT WEATHER?

When you can go out in your garden and pick a few nice slicers just before meal time, they taste ever so much better than those found in the market in more or less wilted condition. Plant a hill of Cucumbers wherever there is room. The more you gather the more th your cucumbers as soon as they reach edible size.

ret and in booklet "Better Gardens." Booklet costs 25 c, or free with $\$ \mathbf{2 . 0 0}$ order.

Each packet of Cucumber seed will plant 12 to 15 hills.

102 Early Klondyke An extra-early strain of White fruit and uniformly dark green skin. Popular with southern planters who grow for the early northern markets, and equally desirable for the home garden. Pkt. 5c, ounce 15c, $1 / 4$ lb. 35c, lb. $\$ 1.00$.

103 Davis Perfect Long, slim, smooth, and especially ndsome for its healthy dark green it always brings the highest rruit often grows 10 to 12 inches long, and the tender, sparkling, white flesh makes it most desirable for slicing on your table. Pkt. 5c, ounce $20 c, 1 / 4$ lb. 50c, lb. $\$ 1.50$.

\section{Improved White} Spine The best-known and univermore extensively grown than any other. No other variety excels it in productiveness, and in color, form, and quality it is all that can be desired. Normal size 6 to 7 inches long and $2 \frac{1}{2}$ inches in iameter. Pkt. 5c, ounce pkg. 15c, $1 / 4$ lb. 35c, lb. $\$ 1.00$.

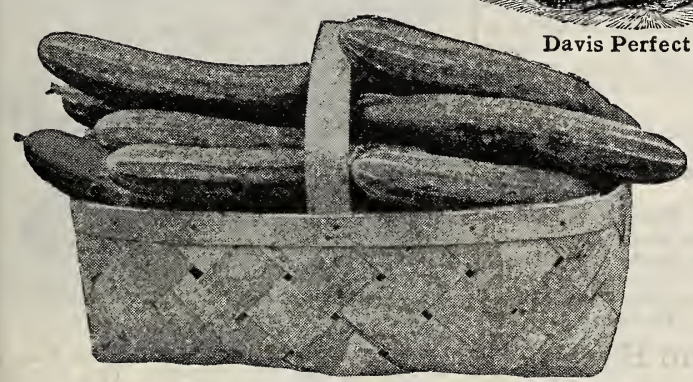

Extra Long Green Cucumber

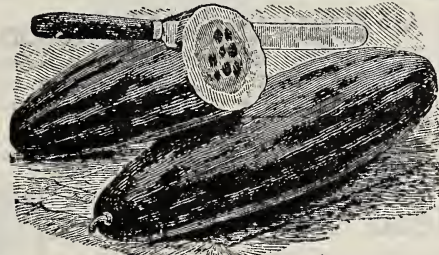

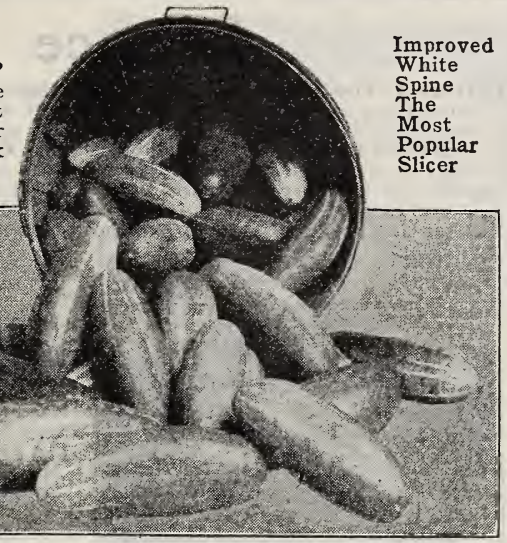

105 Jersey Pickle Very proexceedingly popular. Largely planted for pickles. The fruits are short, smooth, bright green and of excellent quality. We recommend Jersey Pickle for the home garden, as it is a good slicer as well as pickler. Pkt. 5c, ounce $15 \mathrm{c}, 1 / 4 \mathrm{lb}$. 40c, $1 \mathrm{~b}$. $\$ 1.15$.

\section{Chicago Pickle}

Meets the most exacting requirements of critical pickle makers. It is the right size, shape and color, and is one of the heaviest yielders and most dependable varieties. Pkt. 5c, ounce pkg. 15c, $1 / 4 \mathrm{lb}$. 30c, lb. 90c.

\section{Extra Long Green}

A niodel in size, form, and color. Uniformly long and smooth, deep green in color. A money maker for the market gardener and a universal favorite for home use. Fruit 12 to 15 inches long, flesh solid and crisp with few seeds. Vines vigorous and productive. Our strain is extra good. Pkt. 8c, ounce 25c $1 / 4$ lb. 50c, lb. $\$ 1.50$.

108 Japanese Climbing This variety is actually a climber. It climbs quickly on splendid for pickling or slicing. Long, attractive, deep green, smooth fruit. 10 to 12 inches in length. A valuable variety for small gardens. Pkt. 5c, ounce 15c, $1 / 4 \mathbf{l b}$. 50c, lb. $\$ 1.50$.

Irish Queen or New Emerald $\begin{aligned} & \text { Be sure to see the full description of this variety } \\ & \text { among the specialties. See No. } 32 \text { on page } 6 .\end{aligned}$

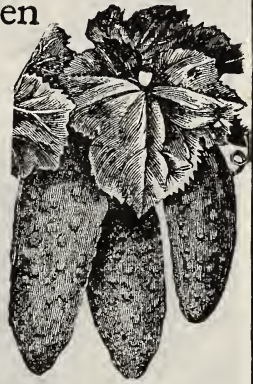

Chicago Pickle

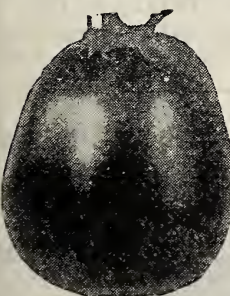

Egg Plant

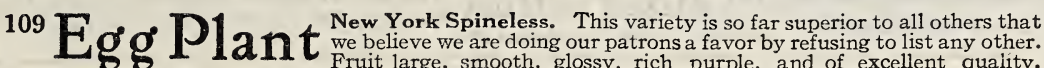
Cultural instructions on each packet. Pkt. 10c, 1/4 ounce pkg. 20c, 1 ounce $50 \mathrm{c}$.

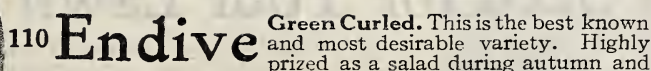
early winter. Also may be served like Spinach. Seeds should be sown in July and transplanted in rows last of August. For early summer use sow seed in early spring. Blanching may be done by tying up the outer leaves or by covering with straw. Pkt. 5c, ounce pkg. 15c.

111 TT 1 ; (Early White Vienna)Also called "Turnip RootCO 11 a 1 1 ed Cabbage." Forms large turnip-like bulbs on young and tender, when they are stem above ground. Should be used while cabbage. Very much sweeter than Turnips. Pkt. 5c, $1 / 4$ oz. pkg. 10c, oz. 25c.

$112 \mathrm{TT} 1$ or Borecole. Popular boiling-greens for fall, winter, and 1 $1 \mathrm{e}$ spring. Very popular in the South. Quite hardy and deserves more general cultivation in the North. Freezing does not injure but improves the quality. Pkt. 5c, $1 / 2$ ounce pkg. 15c, ounce 25 c.

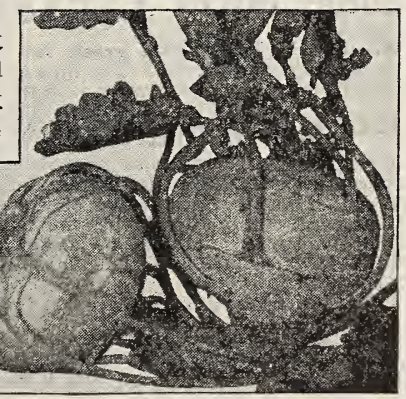

Kohlrabi

113 Tized Tour garden is not complete without a row of the good old-fashioned herbs V1Xed 1 erbs such as Dill, Anise, Sweet Basil, etc. In the old days herbs wer 


\section{Lettuce}

Lettuce is the most popular of all salad crops. It is mighty convenient to have plenty in your garden to be had at a minute's notice. For an all season supply you must make several plantings and of more than one variety. For instance, Grand Rapids comes quickest in early spring, but for summer you want a butter-headed variety like California Cream Butter. Fill up the vacant places in your garden with lettuce-both early and late. Our booklet, "Better Gardens," tells how to grow head lettuce to perfection.

CULTURE-Detailed instructions on each packet and in booklet, "Better Gardens." Booklet free with $\$ 2.00$ orders.

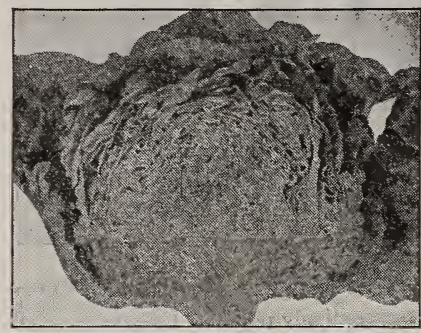

Improved Hanson Lettuce
Each packet contains about a quarter ounce.

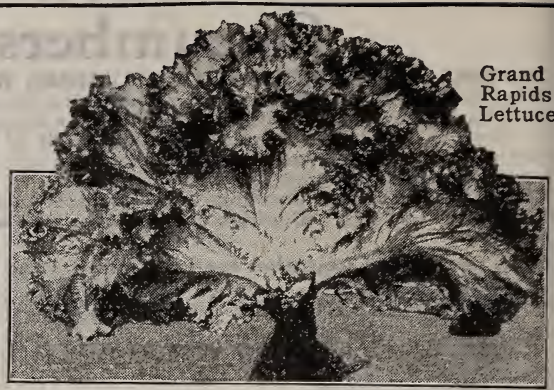

\section{Curled or Loose Leaf Lettuce}

114 Grand Rapids In our trial grounds last season this was the first . big loose heads with bright green crinkled and curled leaves are very attractive,
tender and crisp. Used almost exclusively for forcing during the winter. tender and crisp. Used almost exclusively for forcing during the winter. The
heads remain fresh several days after cutting. Pkt. 10c, ounce 20c, 1/4 Ib. 45c. 115 Early Curled Simpson One of the most satisfactory varieties for larly outdoor planting, forming large, loose heleaves are ruffled and curled, The best cut-and-come-again leaf heat and remains in edible condition a long time. The best cut-and-come-again leaf Lettuce. Pkt. 5c, ounce 15c, 1/4 lb. 35c.

116 Early Prize Head ("The Red Lettuce"). One of the best of the thin-leaved varieties for the home garden, tender, crisp and sweet, forming large loose heads, Purled or crimped, bright green, tinged with brownish-red at the edges,

\section{Cabbage or Head Lettuce} 117 Big Boston A fine big, crisp tender, cabbage - heading Lettuce. grown in the South to supply the Northern winter and early spring market. and equally good for growing in the home garden, both for early spring and autumn planting. Pkt. 5c, ounce 20c, $1 / 4 \mathrm{lb}$. 45c.

118 Burpee's Wayahead An extra-early head Lettuce productightly folded, the inner leaves blanching to a rich, buttery yellow. Always crisp and tender. Pkt. 5c, ounce $15 \mathrm{c}, 1 / 4 \mathrm{lb}$. 35c.

119 Improved Hanson In table quality the Hanson is perfec-

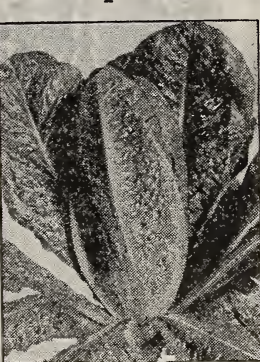

Cos or Celery Lettuce Forms immense, tender, crisp heads that remain long in good table condition. The outer leaves are edges. Pkt. 5c, ounce $15 \mathrm{c}, 1 / 4 \mathrm{lb}$. 30c.

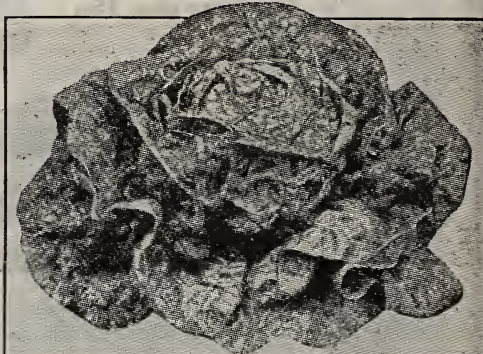

Big Boston Head Lettuce 120 California Cream Butter (Royal Summer Cabbage or German Butare a rich, creamy yellow inside and of a tender buttery flavor. Outer leaves, green, spotted brown. Stands hot dry weather remarkably well. Pkt. 5c, ounce 15c, $1 / 4 \mathbf{l b}$. 35c.

121 New York (Wonderful or Cabbage). One of the largest varieties grown, forming dark green, but the heart blanches white, crisp and tender. Pkt. 10c, ounce 20c, $1 / 4$ lb. 50c.

$122 \mathrm{Cos}$ (Romaine, or Celery). An entirely distinct type of Lettuce that should be more heads largely grown. By many considered superior in quality to all others. Forms oblong Grown large size, the main rib of each leaf curving inward, and blanching white and tender.

123 Mixed Lettuce This is certainly a bargain packet and you will be interested in develop. Pkt. 3c, ounce 10c.

\section{Sunny Places Grass Seed for Your Lawn shady Places}

Would you like a fine green lawn? Success in making a lawn depends on the quality of the seed, and on the proper preparation of the soil. The time to sow the seed is just as early in spring as the soil can be prepared. But don't undertake to prepare the soil when it is wet and soggy.

124 Ideal Mixture Is a carefully blended mixof hardy grasses best suited to growing a compact durable evergreen sod: Kentucky and Canada Blue Grasses, Red Top, Red Fescue, Hard Fescue, Sheep's Fescue, Pacey's Rye Grass and White Clover, a combination that insures a fine velvety lawn. Large package for bare spots, $10 \mathrm{c}$, $1 \mathrm{lb} .45 \mathrm{c}, 5 \mathrm{lbs} . \$ 2.00$. One pound sows 350 to 400 sq. feet. 125 Shady Nook Mixture A special mixture eties that will succeed in partial shade, suitable for sowing under shade trees and in shady corners, where the ordinary mixture will not do. Pkg. 15c, 1 lb. 50c.

126 Pure White Clover It is often advisable proportion of White Clover, especially in poor clay soil. Also for renovating old lawns the Clover will of ten take hold where other grasses fail. $1 / 4$ lb. 25c, lb. 75 c, 3 lbs. $\$ 2.00$.

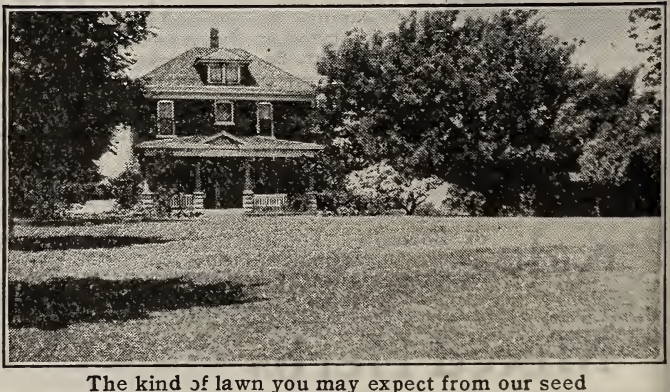

The kind of lawn you may expect from our seed 


\section{Muskmelon}

Each packet will plant 15 to 20 hills.

CULTURE-Detailed instructions on each packet and in booklet, "Better Gardens." Booklet free with $\$ 2.00$ orders.

New Golden Hearts The sweetest melon imaginable. See full 127 Gold Lined Rockyford or Delicious. This new melon retains Gold Lined Rockyford all the good qualities of Rockyford, and is superior in many respects. Introduced by J. C. Robinson, the veteran Vine Seed Grower, is a guarantee of its high qualities. The green flesh, which is remarkably sweet and juicy, has a lining of gold, which greatly adds to its table attractiveness. Pkt. 10c, oz. 20c, $1 / 4$ lb. 60 c.

128 Extra Early Knight Extra early, highest quality. Medium size. Very sweet Flesh, green blending to pink. Pkt. 10c, oz. 20c, 1/1 1b.60c.

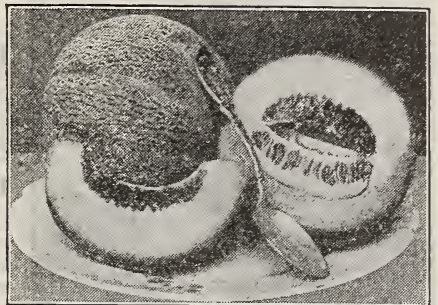

Gold Lined Rockyford or Delicious 129 Banana An odd melon because of better than any other. Skin smooth, and the color of a banana. Grows 18 to 24 inches long. Flesh very thick with small seed cavity. The thick orange flesh melts in your mouth. Pkt. 5c, ounce 15c, $1 / 4$ lb. 50c. 130 Emerald Gem Grows just the your table, and is sweet as honey. For the home garden it cannot be too highly praised. The melon is not large, but very prolific. In shape it is round, slightly flattened at the ends. Skin emerald green under the netting. Flesh rich orange-yellow. Mature early. Pkt. 5c, oz. 15c, $1 / 4$ lb. 50c.

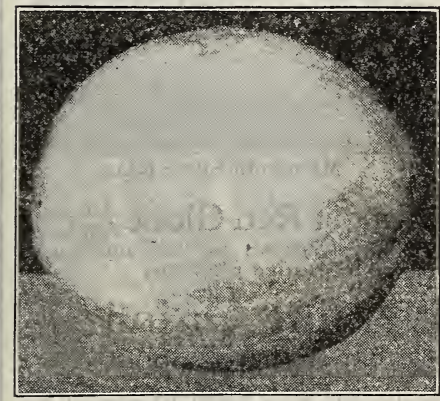

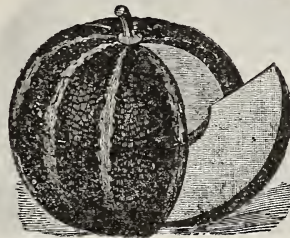

Emerald Gem 131 The Famous Honey Dew An entirely distinct melon that created a sensation when first placed on the market. The fruit is quite large, 8 to 10 lbs., nearly round, perfectly smooth skin. Color nearly white turning to a light lemon-yellow when fully ripe. When cut open revealing the crisp green flesh, it makes a beautiful contrast. In quality it is indescribably sweet with a distinctive delightful flavor. Pkt. 10c, ounce pkg. 20c, $1 / 4$ lb. 50c.

132 Osage or Miller's Cream, sometimes One of the best known and desirable melons to plant. Size medium large, almost round, deeply ribbed. Color dark green, with lighter bands between the ribs. Flesh very thick, rich orange salmon, and of superb quality, sweet and melting. Pkt. 5c, ounce pkg. 15c, $1 / 4$ lb. 40 c.

133 Rocky Ford The best known largely grown than any other. Flesh green is Northern grown, insuring early maturing crops. Pkt. 5c, ounce pkg. 10c, $1 / 4 \mathrm{lb} .35 \mathrm{c}$ 134 Vine Peach or V e g e t a b l e vine similar to Muskmelon, requiring the same

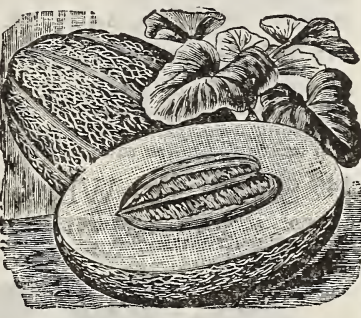

Osage Muskmelon cultivation. The fruit is about the size and color of an orange. The fruit has a delightful aroma, and it is novel enough to be well worth growing. Recommended for sweet pickles, preserves or pies. Instructions how to cook and preserve on each packet. Pkt. 10c.

The Famous Honey Dew

Watermelon

CULTURE-Detailed instructions on each packet and in booklet "Better Gardens". Irish Gray Illustrated and described on page 7, No. 36.

135 Cole's Extra Early Decidedly the finest variety for the home garden medium size and nearly round. Skin mottled dark and light green; flesh dark red, of granulated sparkling appearance, very sweet. Pkt. 5c, oz. 10c, $1 / 4$ lb. 30c, 1b. 90c. 136 Golden Honey If you are prejudiced against golden fleshed watermelon, rightly named, as the flesh is golden yellow, and sweet as honey. Fruit medium large, oblong, dark green. Try a packet. Pkt. 5c, ounce pkg. $15 \mathrm{c}, 1 / 4 \mathrm{lb} .40 \mathrm{c}$.

137 Halbert's Honey One of the finest melons for uscious quality. Medium large, oval. Dark glossy green flesh bright crimson. Very tender and sweet. Pkt. 5c, oz. pkg. 10c, $1 / 4 \mathrm{lb}$. 30c, lb. $90 \mathrm{c}$.

138 Citron (Redseeded). The citron makes to grow, keep dicious preserves. They are easy a nice recipe printed on the packet.Pkt.5c, oz. 15c.

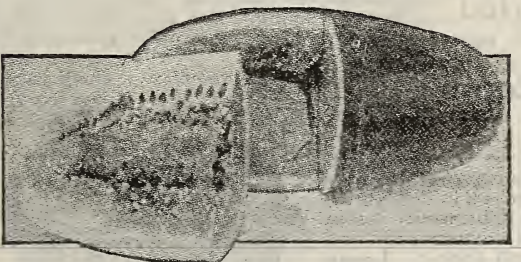

Kleckley's Sweets

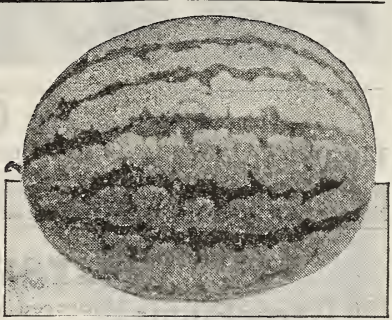

Cole's Early Watermelon

139 Kleckley's Sweets A general favorite with all lovers of A general favorite with all lovers of
sweet and luscious melons, and

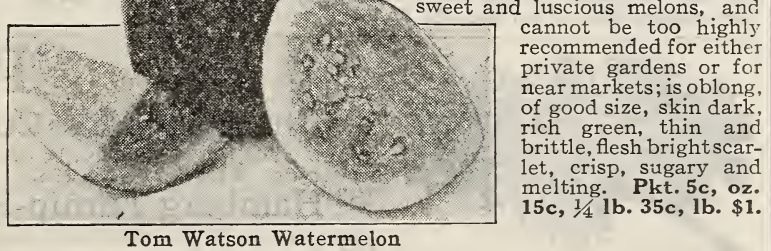
140 Tom Watson The most popular of all melons. Very largely size and very heavy; flesh bright red and of excellent quality. We sold 60,000 packets of this variety in 1922 . Pkt. 5c, oz. pkg. 10c, $1 / 4$ lb. 30c. 141 Sweet Heart Large, oval fruit. Dark green, mottled light. oz. pkg. 10c, $1 / 4$ lb. 25 c, lb. 75 c. 


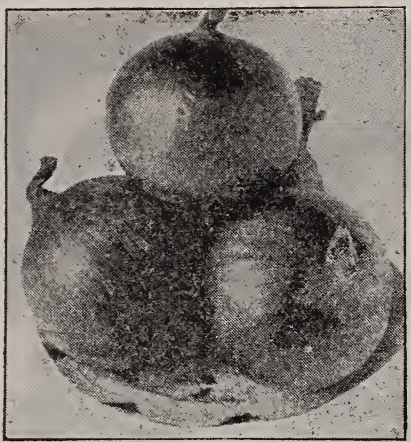

Ohio Yellow Globe Danvers

144 Prizetaker A splendidlarge to grow for fall markets or homety With favorable conditions they may be grown from seed, to weigh two pounds or more. Handsome, straw-yellow skin, resembling the imported Spanish Onion. Very productive. More than 500 bushels have been grown to the acre excellent flavor. Pkt. 5c, oz. 20c, $1 / 4$ lb. 60 c, 1 b. $\$ 2.00$. 145 Mammoth Silver King This mammoth white variety is one of formly large size and fine shape, being flattened but thick. The skin is of a beautiful silvery white, flesh snowy and tender, of a mild, sweet flavor. Its large size and handsome appearance recommend it for exhibition at fairs, for the fancy market, as well as for the home table. Pkt. 10c, ounce pkg. 25c, $1 / 4 / 4$ lb. 75c, lb. $\$ 2.50$.

146 Southport White Globe The most attractive white Onion est market prices. Perfect globe-shape, and clear, transparent skin; flesh crisp, fine grained, and mild in flavor. Pkt. 5c, ounce pkg. 20c, $1 / 4 \mathrm{lb}$. 70c, 1 b. $\$ 2.40$.

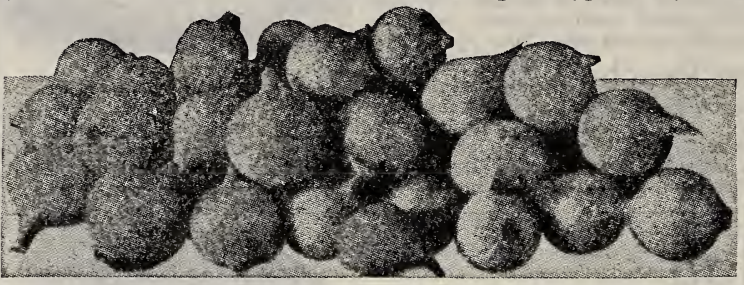

147 Southport Red Globe A beautired Onion. Largely grown for fall and winter markets. Pkt. 5c, ounce pkg. 15c.

\section{Pickling Onion}

148 Extra Early Silver Bell ${ }_{\text {earliest }}^{\mathrm{T}} \mathrm{h}$ e Onion in cultivation, being a selected strain of the Italian Barletta. 'The skin is pure transparent, waxy, silver-white; very mild flavor. Pkt. 8c, ounce pkg. 25c, $1 / 4$ lb. $75 \mathrm{c}, 1 \mathrm{~b}$. $\$ 2.50$.

\section{Okra or Gumbo}

149 White Velvet arate dish and for soups. The tender seedpods are cooked like asparagus. Should be more largely grown in the North. Pkt. (100 to 125 large seeds) 5c, oz. pkg. 10c, $1 / 4$ lb. 25c.

\section{Parsnips}

150 LargeSugar Improved Hollow Crown or Guernsey. than tender and sweet. Generally considered the best. Then why should we confuse the buyer by listing 3 or 4 other varieties? Fresh parsnip seed is very scarce this year, and fresh seed is necessary for success. We have a limited supply and advise early orders. Pkt. 5c, large ounce pkg. 20c, $1 / 4 \mathrm{lb}$. 60c, lb. $\$ 1.75$.

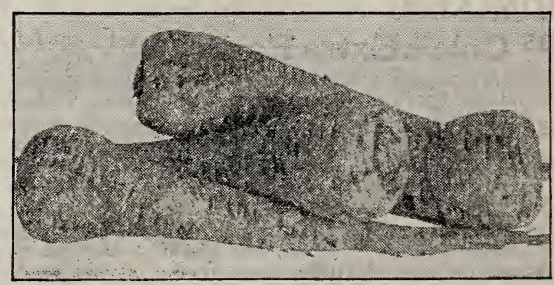

Large Sugar or Improved Hollow Crown

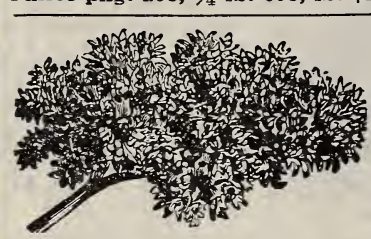

\section{Parsley} 151 Champion Moss Curled Very useful for flavoring soups or stews, winter use. Pkt. 5c, ounce 15c. 152 Hamburg Turnip-Rooted $\begin{aligned} & \text { The roots which resemble a small par- } \\ & \text { snip } \text {, }\end{aligned}$ are esteemed for flavoring soups, etc. For winter use, store the roots same as Turnips. Pkt. 5c, ounce, 15c.

153 Extra Early Spanish Peanuts ${ }_{\text {It is not generally known that Peanuts }}$ By planting the extra early Spanish, they mature a nice crop if planted on light, sandy soil in full sunshine. The nuts are not quite so large as the ones usually sold, but are very solid and sweet. Just what the boys will want to plant. Culture instructions on each packet. Large pkg. 5c, $1 / 4 \mathrm{lb} .15 \mathrm{c}, \mathrm{lb} .40 \mathrm{c}$.

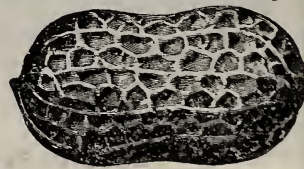




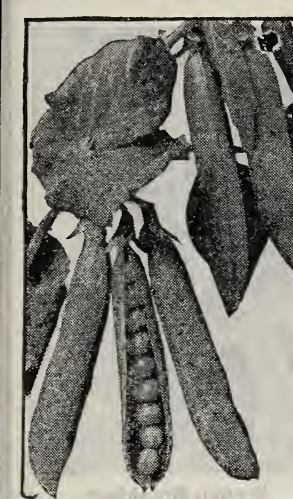

Alaska Peas

\section{Garden Peas}

One-fourth pound will plant a $50 \mathrm{ft}$. row.

Peas from your own Garden-Picked only an hour or two before eating are twice as sweet as those that have been in a store for a day or two. That is a proven fact. Peas produce early-...they make your garden begin to pay quick. They do well on any fair garden soil-easy to tend, requiring little attention, and everybody likes sweet fresh peas. Plant both early and late varieties so that there will always be plenty to fill the basket.

CULTURE-Detailed instructions on each packet and in booklet "Better Gardens."

154 Extra Early Alaska or Earliest of All. The hardiVery productive. Peas smooth, bluish green, very fair quality. More extensively grown for early market than any other variety. Height 2 feet. $1 / 4$ lb. pkt. 10c, lb. 35c, 3 lbs.90c. (Postage paid on all peas.) 155 First-in-Market Extra-early, smooth, white seeded. $21 / 2$ inches long. Our strain is same season as Alaska and yields about 10 per cent more. $1 / 4$ lb. pkt. 10 c, lb. 35c, 3 lbs. 90c.

156 Nott's Excelsior The earliest dwarf wrinkled pea. A sturdy, compact, dwarf growth, 18 to 20 inches fine, highly bred variety of cious peas of unusually sweet flavor. Large $1 / 4$ lb. pkt. 12c, lb. 40c, 3 lbs. $\$ 1.00$. 157 Thomas Laxton The best quality and heaviest yielding of all vines 112 ftal Laxton early tall peas 10 days later than Alaska, ang broad, handsome, packed full of deliciously sweet peas. You can pick enough for a nice meal in short order. Outyields the
old favorite Gradus fully 25 per cent. $1 / 4 \mathbf{l b}$. 15c, lb. 40c, 3 lbs. $\$ 1.00$. Old favorite Gradus fully 25 per cent. $1 / 4$ lb. 15c, 1 b. 40 c, 3 lbs.
Peter Pan The best dwarf pea. See No. 38 on page 7.

158 Alderman Height $41 / 2$ feet. Of the well known Telephone productive, Peas of but of a darker green color. Very robust and the large main-crop varieties. $1 / 4 \mathrm{lb}$. pkt. $12 \mathrm{c}, 1 \mathrm{lb}, 40 \mathrm{c}, 3 \mathrm{lbs}$. $\$ 1.00$.

\section{Edible Podded Peas}

159 Mammoth Melting Sugar $\frac{\text { Height } 5 \mathrm{ft} \text { Well deserves }}{2}$ its name. Should be cooked and eaten pods and all the deserves Thomas its name. Should be cooked and eaten pods and all, the same as Laxton wax beans. Pods are stringless and when cooked are tender, Peas sweet and sugary. $1 / 4$ lb. pkt. $15 \mathrm{c}, \mathrm{lb}$. $45 \mathrm{c}, 3 \mathrm{lbs} . \$ 1.15$.

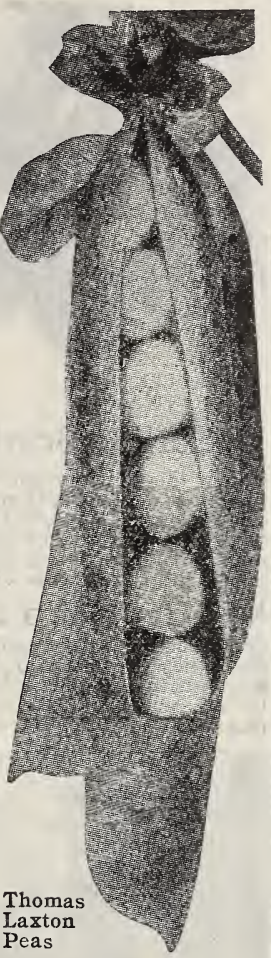

160 Dwarf Gray Sugar Height 18 inches. Similar to Melting Sugar, but of pods about 3 inches in length. $1 / 4 \mathrm{lb}$. pkt. 12c, lb. $40 \mathrm{c}, 3 \mathrm{lbs}$. $\$ 1.00$.

Remember that our prices on Peas include postage to your home.

Theresa B. Wiley of Oxford, Pa., writes:

We had wonderful success with the seeds which came from your place and raised some fine, big vegetables. We can recommend them to anyone, for all the seeds proved to be just as you say they are. When I want either flower or vegetable seed you will receive my order."

\section{Peppers}

Each packet will contain 200 or more seeds.

161 New Royal King A fine new variety, an improvement over the popular Ruby Our seed was procured from the introducer. Owing to its fine quality, you make sales at highest prices, even when the market is glutted with other varieties. Pkt. 10c, 1/4 oz. pkg. 20c.

162 New Early Sweet Salad A new sweet, upright Pepper, so sweet that it may upright, not drooping. Just the right size for stuffing and frying. Pkt. 10c, 1/4 oz. 25c.

163 Small Hot Varieties A mixture including Cayenne, Celestial, Tabasc, Coral interesting as ornamental plants. Pkt. 5c, $1 / 4$ ounce pkg. 15 .

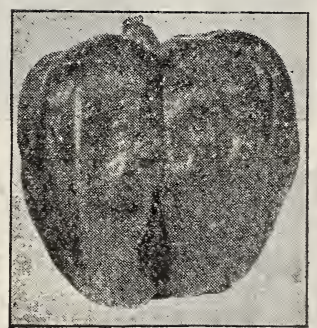

Royal King Pepper

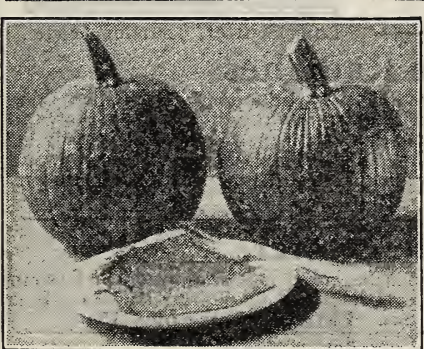

Small Sugar Pie Pumpkin

\section{Pumpkins}

Each packet will plant 10 to 15 hills.

$164 \mathrm{Small} \mathrm{Sugar} \mathrm{Pie}$ Is so well known as the best pie pumpkin it medium size, with solid fine grained flesh, and such a sweet, sugary, delicious flavor they all call for "more." Pkt. 5c, oz. pkg. 15c, 1/4 lb. 40c.

165 Tennessee Sweet Potato Excellent sort which resembles a shaped and slightly ribbed. Color creamy-white, sometimes striped with green. A first-class keeper. Flesh light colored, fine grained, very dry and of superior flavor. Pkt. 5c, oz. pkg. 15c, $1 / 4 \mathrm{lb}$. 40c.

166 Jumbo or King of Mammoths. Fruit enormous size- often 150 to 200 pounds. A great stock feeder. Orange skin and yellow flesh of fair next fall. Pkt. 8 c, oz. pkg. 20c, $1 / 4$ lb. 50 c.
for 


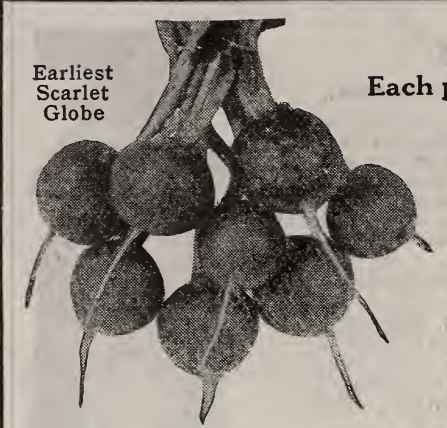

\section{Radishes}

\section{Earliest Scarlet Giobe}

packet contains nearly 1000 seeds

To be at their best, radishes must grow quickly. Then they are crisp and not too hot. Choose light mellow soil, not recently manured. For earliest use, plant the short round varieties; for later, the long kinds. Thin out so that they are not over-crowded in the row.

CULTURE-Detailed instructions on each packet and in booklet "Better Gardens."

\section{Radish Seed Quality}

There are two kinds of Radish Seed. One will produce good, crisp roots; the other will run to tops. Our seed has been carefully selected for its root forming quality and will give you crisp, sparkling roots.
This is the most popular of the extra-early globe varieties. It is of rapid growth, brilliant scarlet in color. Has small tops, and is probably more largely grown for home and market than any other va-
riety. We have a very fine strain. Pkt. 5c, ounce pkg. $12 \mathrm{c}, 1 / 4 \mathrm{lb}$. 35c, lb. 90c.

168 White Tip Scarlet Gem or Sparkler. A very early and attractive variety of the globe or turnip shaped class. Bright scarlet with a distinct white tip. Very popu-
lar for home and market. Pkt. 5c, ounce pkg. 10c, $1 / 4$ lb. 30c, 1b. 85c.

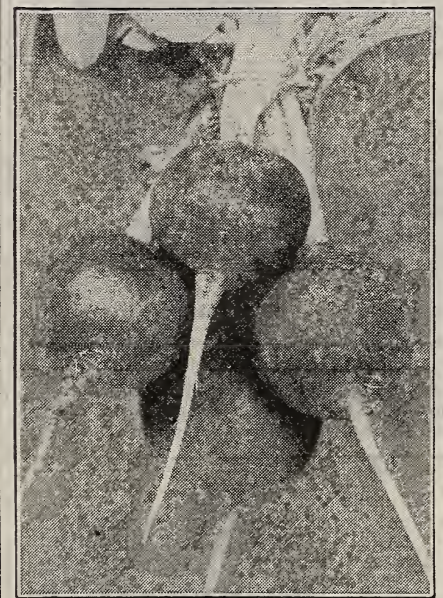

Crimson Giant

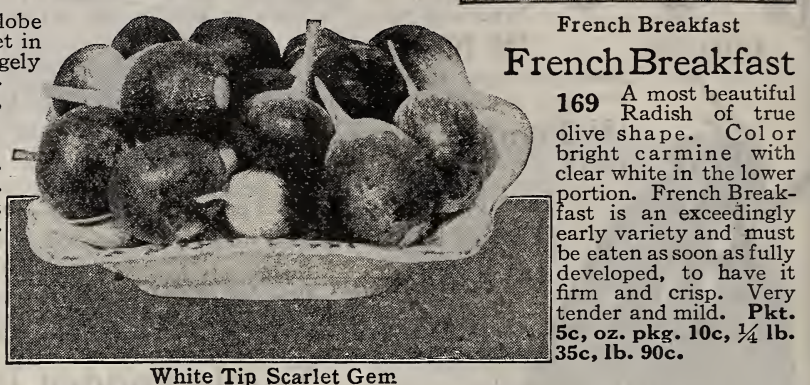

170 Crimson Giant Globe Also called Giant Butter. A rapid rrows large and remains in edible condition longer than other early round sorts. Roots attractive deep crimson-suitable for forcing or outdoor planting. Excellent eating quality. Pkt. 5c, oz. 12c, $1 / 4$ lb. 35c, lb. $\$ 1.00$.

171 White Box A popular, early, round radish with white skin, and crisp 172 Earliest Long Scarlet The finest strain of this very popular nice and taste good, crisp and appetizing. plant for second early, ready in about 35 days. Pkt. $5 \mathrm{c}, 0 z .10 \mathrm{c}, 1 / 4 \mathrm{lb}$. 25c, $1 \mathrm{~b} .80 \mathrm{c}$.

173 Long White Icicle The finest ish grown. Long slender root which remains tender and crisp until grown. Matures early, has small top which permits close planting. Many people like white Radishes best of all. Pkt. 5c, ounce pkg. 10c, $1 / 4$ lb. 30c, lb. 80c.

174 Chartier or Shepherd. A sumedible after the early kinds. Attractive long red roots with waxy white tip. Crisp and tender. Pkt. 5c, oz. 10c, $1 / 4$ lb. 25c, lb. 70c.

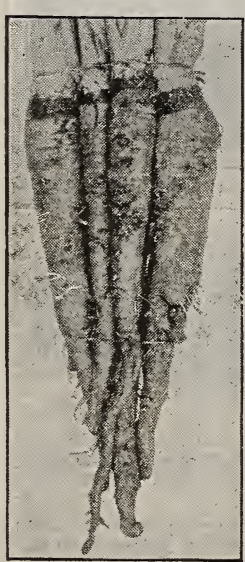

175 All Seasons Radish Mixture Each packet mixture of all the above described varieties. An interesting packet for small gardens. Pkt. 5c, oz. 10c, 1/4 lb. 25c, lb. 60c. 176 Winter Radishes Winter Radishes should be planted in August. If planted in early spring, they will run to seed without forming roots. China Rose, Celestial or Mammoth White China, and Long Black Spanish. Store the same as turnips for winter use. Pkt. 5c, ounce pkg. 10c, $1 / 4$ lb. 30c, lb. $\$ 1.00$.

\section{Interesting Japanese Radishes}

An interesting packet, containing a mixture of the following varieties: Japanese Bottle Radish, Long String Radish, Mjyashige, Nerima, Mammoth Shogoin and Giant Sa-ku-ri-ji-ma, that grows to weigh 25 to $30 \mathrm{lbs}$. These are all winter Radishes and should not be planted before last of July, as early planting will run to seed and not grow to large size. Try a packet, plant in deep rich soil, and beat your neighbors at your County Fair next fall. They are the largest radishes grown. Pkt. 150 seeds $5 \mathrm{c}$, ounce $25 \mathrm{c}$.

\section{Salsify or Vegetable Oyster}

Why don't you grow Salsify? It is one of the most delicious and nutritious of vegetables. In soup it has a delicious oyster flavor. Also fine if fried in butter, or boiled and made into fritters. It is perfectly hardy and should remain in the garden for spring use. Pkt. 5c, ounce pkg. 15c. 


\section{Squashes}

Each packet will plant 8 to 10 hills.

Have squashes from August until following spring-You can have plenty of these very nutritious delicious vegetables by planting hills of summer, fall and winter varieties. The summer varieties gather and use as soon as the fruits reach good size and before the shell gets so hard it cannot be pierced with the finger nail. The winter varieties gather when the shell is hard and frosts have killed the vines. They will keep all winter. Remember that winter squashes make profitable stock feed during the winter months. For that purpose grow them in the corn field. CULTURE_Detailed instructions on packets and booklet "Better Gardens."

179 Golden Custard Yellow Bush Scallop or Patty-Pan. The earlitender. Pkt. 5c, oz. pkg. 15c, $1 / 4$ lb. 45c.

\section{Giant Summer Crookneck}

The best known early Bush Squash. Skin and flesh deep golden yellow. Very productive and fine quality. A general favorite. Fruits often $2 \mathrm{ft}$. long. Pkt. 5c, oz. pkg. 15 c, $1 / 4$ lb. 45c.

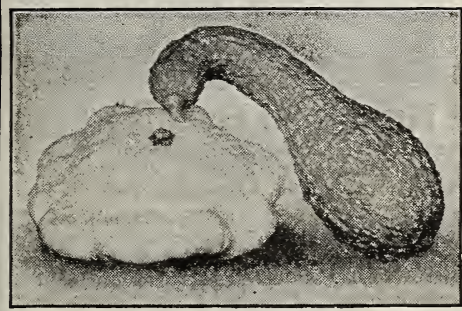

Custard and Crookneck Squash

185 Golden Hubbard

Fruits the same shape as Green Hubbard, but smaller in size. Earlier in the season, but good keepers. Skin deep orange yellow. Quality equal to $\mathrm{Hub}$ bard. Pkt. 5c, oz. 20c, $1 / 4$ lb. 55c.

\section{Mammoth Chili}

A mammoth exhibition squash - the largest grown. Has been grown to weigh more than 200 pounds. Skin and flesh orange yellow, of very fair quality for eating and good stock feed.

Pkt. 10c, oz. 25c.

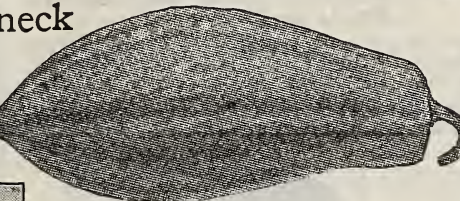

Fordhook Squash

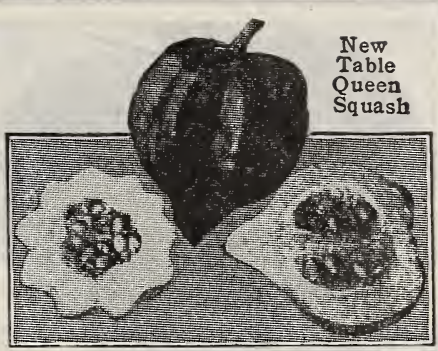

181 Fordhook A desirable both summer and winter use. One housewife told us it was the best summer squash she had ever eaten. In our trial grounds it was ready to eat very arly. A good keeper. Fruit, 8 to 10 inches long. Skin light yellow, shell hard, flesh very thick. Cooks mealy and dry. Each vine produces many squash. Pkt. 5c, oz. 20c, $1 / 4$ lb. 55c. 182 New Table Queen $\begin{gathered}\text { Also called Des Moines. The introducer } \\ \text { says: "Just wash it clean, cut it in half, take }\end{gathered}$ out the seed and bake 20 minutes, and you will have the nicest squash you ever tasted," Splendid for pies. Table Queen is just the right size, a veraging 6 to 8 inches long, and 5 to 6 inches in diameter. Color is dark green, sometimes with blotches of red at pointed end. Shell smooth and hard, ripens in the fall, and keeps as long as Hubbard. Pkt. $10 \mathrm{c}$, ounce $25 \mathrm{c}, 1 / 4 \mathrm{lb}$. 70c.

183 Prolific Orange Marrow Size and shape similar to Huborange yellow. Thick yellow flesh rich and sweet. Excellent for pies. Ready for use before Hubbard, in fall and early winter. Pkt. 5c, ounce pkg, 15c.

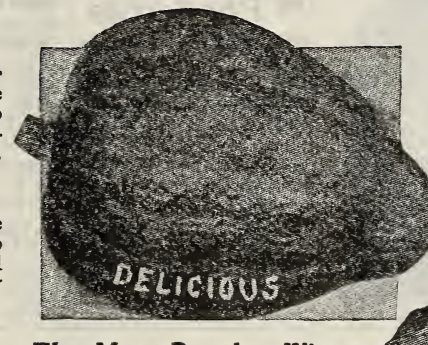

184 Delicious The sweetest of all but not quite as good to keep as Hubbard. About the size of Hubbard. Color dark green. Flesh thick, dark orange in color. Very dry, sweet, and of rich flavor. A squash of exceptional merit for table use. Usual weight 5 to 10 pounds. Pkt. 5 c, oz. pkg. $20 \mathrm{c}, 1 / 4 \mathrm{lb}$. $50 \mathrm{c}$. Hubbard Squash. You will enjoy this squash from late fall until spring. Delicious for baking and rivaling the best pumpkin for pies. Has deep orange flesh. The best and most profitable to grow of all winter squashes. Our strain grows large, has dark green, moderately warted shell and has been selected to give fruit of greater weight and food value than the ordinary Hubbard squash. Pkt. 5c, oz. 20 c, $1 / 4$ lb. 50c, 1b. $\$ 1.50$.

"Your seeds make good gardens," says J. R. Stanton of Galesville, Wis. "Although the writer sent you only a small order in I022, having only a small garden, I want to express my entire satisfaction, as every seed I had from you came fully up to expectations, and the little garden will be planted next year with your products exclusively."

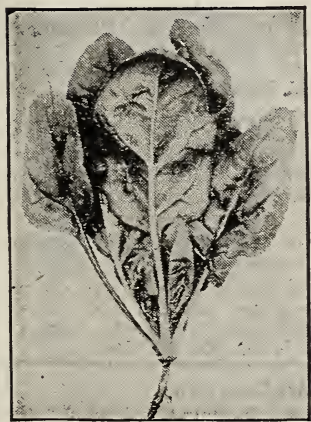

Bloomesdale Spinach

\section{Spinach}

King of Denmark Antvorskov. Bears longer without going to seed. A 188 Bloomesdale Savoy A most valuable variety. In appearance the leaf is hence the name. It is a very early variety, also the same way as that of the Savoy Cabbage, plant is of upright growth, matures quickly, and is a heavy yielder. Suitable for the home garden. For a continual supply sow every ten days until middle of May. Pkt. 5c, ounce $10 \mathrm{c}, 1 / 4 \mathrm{lb}$. 20c, lb. $50 \mathrm{c}, 5 \mathrm{lbs}$. for $\$ 2.00$.

189 New Zealand Spinach Tetragonia or Everbearing Spinach. The spinach greens all summer. Of fine quality producing its tender leaves throughout the hottest summer weather without going to seed. This is an entirely distinct species, forming low spreading plants and smaller leaves-but the leaves and branches are very thick and juicy, and are served the same as other varieties of spinach. Pkt. 5c, oz. 15c, 1/4 lb. 30c, lb. 75c.

\section{Mammoth Russian Sunflower}

The best egg-producing food known for poultry. Every farmer should plant some of the seed in any out-of-the-way place at any time in May or June. Single heads will often measure 15 to 18 inches across and contain an immense quantity of seed. Hang the heads in the poultryhouse, where the hens can reach them, and they will do the rest. This is the variety that farmers in some states now grow for silage. Ounce pkg. 5c, $1 / 4 \mathrm{lb}$. 10c, lb. 25c, $3 \mathrm{lbs}$. 65c. 


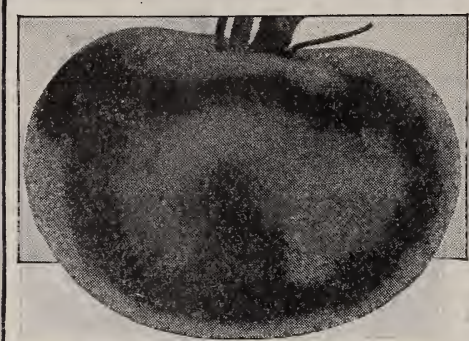

The Landreth Tomato

\section{Tomatoes}

Each packet of Tomato Seed will produce 350 to 500 plants. CULTURE - Instructions on each packet and in booklet "Better Gardens."

191 Sparks' Earliana There are a number of Tomatoes that are cound any earlier than our strain claimed to be the earliest, but we have never est, deepest tomatoes for our seed so your crop will inherit that tendency. The fruit is of medium size, bright scarlet and of excellent quality. Plant Earliana to beat your neighbors in earliness. Pkt. $5 \mathrm{c}, 1 / 2 \mathrm{oz} .15 \mathrm{c}, \mathrm{oz} .25 \mathrm{c}$.

192 The Landreth It begins to ripen the first, and continues bearing all summer. The fruit is medium large, and very good to eat or sell. Color red. Pkt. $10 \mathrm{c}, 1 / 2$ oz. 25c, oz. 40 c.

193 Early Acme A popular purple or pink variety. Many people will solid and smoth. Pkt. 5c,

194 Red Rock Second early, bright red Tomato. Popular with canners 195 Dwarf Stone The Dwarf or Tree able where space is limited. The compact, upright plants require little space, and no staking, yet they yield heavily for a long season. Dwarf Stone is the best of the dwarf class. Fruit smooth, red, medium size, fine quality. Pkt. 5c, $1 / 2$ oz. 20c, oz. 35c.

The Norton New wilt resistant variety. Gulf State Market ing of all tomatoes. See No. 39 on page 7.

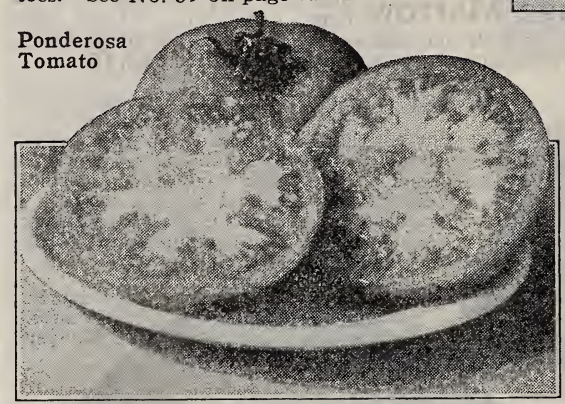

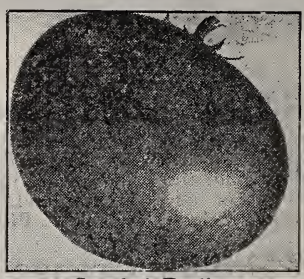

Sparks' Earliana

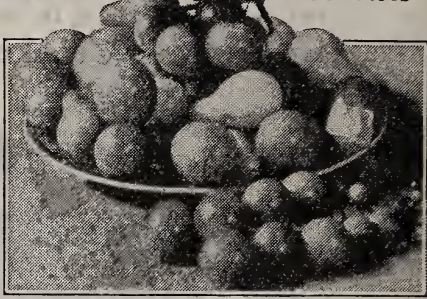

196 New John Baer Extra - early. enormously productive. We believe it 197 New Stone "King of the Reds." 197 New Stone The standard main-crop variety. The fruit is of uniformly large size, smooth, very solid, and of best table quality. Fine for canning. Pkt. 5c, $1 / 2$ oz. 15c, oz. 25c. 198 Ponderosa "Beefsteak." This is not only the largest glowing purple-crimson. Considered by many the best table variety in existence, especially by those who prefer a tomato quite free from acid. Being very solid, with few seeds, it is very desirable for slicing. Pkt. 10c, $1 / 2$ ounce pkg. 25c, oz. $45 c$.

199 Golden Oueen The best Yellow Tomato, and you will Golden Queen feel well repaid if you try it this year. Good 作 yellow slices served with a bright red variety make a tempting dish. Fruit good size, smooth, solid and richly colored. Pkt. 5c, $1 / 2$ oz. 20c. 200 Small Preserving An interesting mixture comprising Pear, Plum, Currant and Husk Tomatoes. Very desirable for preserves, also dried in sun and packed with sugar make a fine substitute for figs. Pkt. 5c, $1 / 2$ oz. 20c.

\section{Turnips}

Each packet will contain about $1 / 4$ ounce of seed CULTURE-Detailed Instructions on each packet and in booklet "Better Gardens." 201 Extra Early Milan Earliest Turnip in cultivation; a week sooner than bright purple top and few leaves. Flesh white and sweet. For early spring planting, Milan is the most satisfactory; also suitable for fall planting. A good keeper. Pkt. 5c, ounce pkg. 15c, $1 / 4$ lb. 35c, lb. $\$ 1.00$.

202 White Egg Forms a beautiful eggwhite skin. Flesh always firm, solid and sweet. Pkt. 5c, ounce pkg. 10c, $1 / 4$ lb. 25c, lb. 75c.

203 Golden Ball or Orange Jelly. One sweetest of yellow-fleshed Turnips yet introduced. Medium in size. Uniformly smooth and solid. Pkt. 5c, ounce pkg. 10c, $1 / 4$ lb. 25c, lb. 75c.

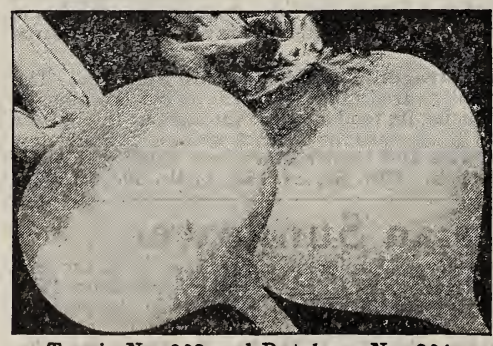

Turnip No. 203 and Rutabaga No. 204

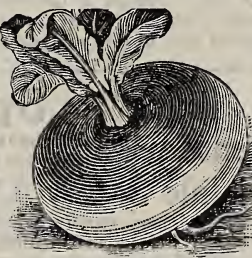

Early Milan

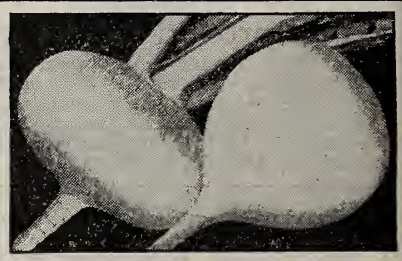

No. 202 Turnips No. 200 204 Purple Top Strap-Leaf The standardfor this part of the country. Superior for early or late planting. Flattened, good sized, small top with but few leaves; flesh very fine; flavor good. Pkt. 5c, ounce pkg. $10 \mathrm{c}, 1 / 4$ lb. 25c, 1b. $70 \mathrm{c}$.

205 Purple Top White Globe

This is one of the handsomest and most desirable varieties grown. Very similar to the above variety, except in shape, being a perfect globe-shape. For home and market. Pkt. 5c, ounce pkg. 10c, $1 / 4$ lb. 25c, lb. 70c.

Mammoth Shogoin A novelty, and the largest variety grown. Mammoth Shogoin See No. 41 on page 7.

206 Rutabaga (American Swede). Produces uniformly large, globebelow. Flesh very solid, roots. Purple above ground, and yellow grown for market and stock. Pkt. 5c, oz. 10c, $1 / 4$ lb. 30c, lb. 85c.

Good news from Norman L. Knauss of McLean, Va.

"Everything I purchased from you last spring was first-class, and I no only appreciate the quality of the goods, but also your promptness in making deliveries. 


\section{QUALITY FLOWER SEEDS}

The word quality in this case means only one thing-that you may plant these flower seeds with the feeling that the results will be very satisfactory. Our "quality" policy is making friends for us by the hundreds of thousands. Gardeners like good flower seeds. Again the list of kinds and varieties have been selected from your viewpoint. You can grow these easily with reasonable care-the "hard to grow" kinds are not offered. Every time you walk into your garden or see a bouquet on the table you are repaid many times over for the amount invested. So plant plenty of flower seeds this year.

The Annuals are listed on pages 21 to 27, Climbers page 28, Seeds of Perennials page 29.

FLOWER CULTURE-Instructions are on most packets and in booklet, "Better Gardens.", The chart on pages 36 to 39 of "Better Gardens" is a mine of flower information.

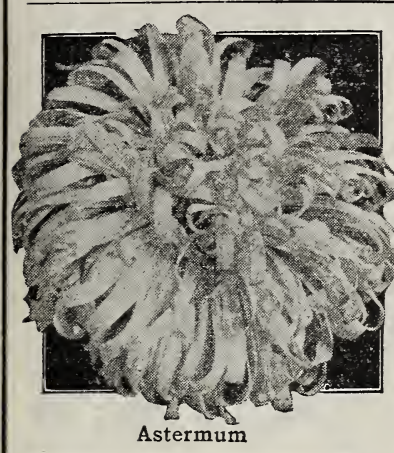

\section{Lovely Asters}

To en joy all summer and fall

The leading types of Asters are offered bere. It is possible to have early ones in bloom in July and others to follow right up to snow. Some border types and others of the stately cut flower varieties. Your friends will marvel at the Asters you can grow from these seeds. The great care exercised by our growers has earned for our Aster seeds a nationpackets annually.

Heart of France The glorious new front cover. See No. 1 on page 4.

207 Queen of the Market

The best of the extra-early varieties, fully two weeks ahead of all others. Flowers quite large and double. Mixed. Pkt. 5c, 1/8 oz. pkg. 15c, oz. 90 c.

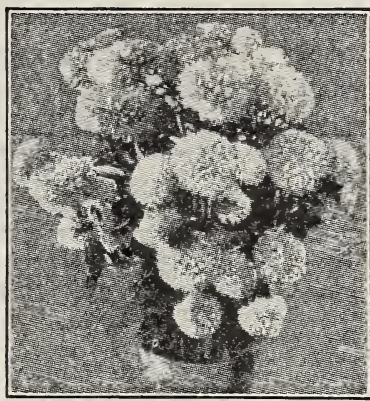

New Daybreak 208 American Branching The best all In their full glory in September. The flowers are big balls of color often 4 inches across, always on long stems, fine for cutting. Mixed colors. Pkt. 5c, $1 / 8$ oz. 15c, oz. 90c. 209 American Beauty One of the most beauintroduction. Of very vigorous habit, producing larg perfectly double flowers on long stems. The color is the "American Beauty" brilliant rosy crimson. Pkt. 10c, $1 / 8$ ounce pkg. 25 c.

210 Astermum Well named, because the shaggy Astermum flowers are really more like Chrysanthemums than Asters. Plants are branching with long stems but rather dwarfer than the Comet type. Mixed colors. Pkt. 10c, $1 / 8$ oz. pkg. 25c.

211 Giant Branching Comet Resem-

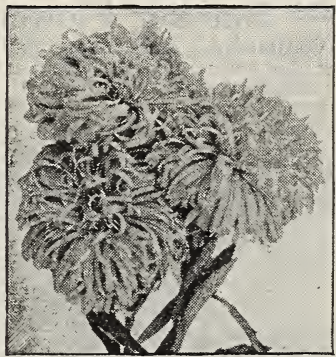

Giant Comet

Queen of the Market

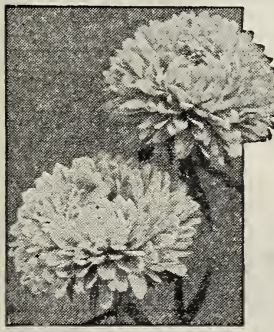

Japanese Chrysanthemum. The flowers are from 3 to $41 / 2$ inches in diameter, perfectly double, on long stems. Mixed colors. Pkt. 10c, $1 / 8$ ounce pkg. $25 \mathrm{c}$.

212 New Giant Crego Strong, well branched plants, 2 feet stems, petals irregularly curled and twisted. Very fine. The longest keeping cut flower. Mixed colors. Pkt. 10c, 1/8 ounce pkg. 20c.

213 New Daybreak Called forth more admiration at our plants were literally bouquets of big double round balls. Uniform compact habit. Unsurpassed for borders. Mixed colors. Pkt. 10c, 1/8 oz. pkg. 25c.

214 New King Aster A distinct new type. Very large folded, needle-like petals. Flowers resemble Cactus Dahlias. Very at tractive, all colors. Pkt. 10c, $1 / 8$ ounce pkg. 25c.

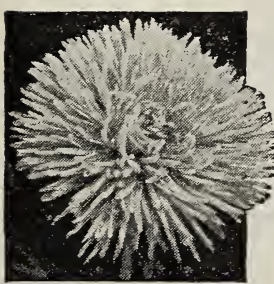

215 Ostrich Plume A fine type of Giant Comet, having producing a plume-like effect. Flowers very large, on long stems; fine for cut flowers. All colors mixed. Pkt. 10c, $1 / 8$ ounce pkg. 20c.

216 Snowball Aster Sturdy plants bearing an abundance early. The best dwarf white Aster. Fine for bedding cutting or the garden border. Pkt. 10c, $1 / 8$ oz. 25c.

Unicum White Pretty novelty. See No. 8 on page 4.

New King

\section{One packet each of above 12 Asters 85 cents}

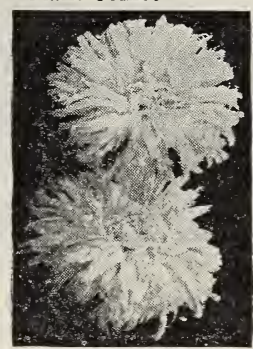

Ostrich Plume

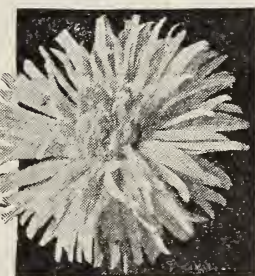

Giant Crego
Asters in Separate Colors $\begin{gathered}\text { Made up from } \\ \text { the most desir- }\end{gathered}$ able varieties, having long stems. Suitable for cutting, bordering or beds. Packets contain at least 250 seeds. 218 Pure White, pkt. 10c. 219 Delicate Pink, pkt. 10c. 220 Blue and Lavender, pkt. 10c.
221 Extra Quality Mixed Asters $\underset{\text { careful- }}{\mathrm{r}}$ y ly prepared-containing all of the separate types we list, and others as well. It will give you a beautiful Aster collection for the price of one packet-types early, midseason and late, and all the colors known to Asters. Plant a quantity of this $1 / 8$ oz. 20 c, $1 / 2$ oz. 75 c, oz. $\$ 1.25$. 


\section{Amaranthus-Three Pretty Foliage Plants}

222 Caudatus "Love Lies,

Long, drooping, bloodred panicles.

Height, 2 to $3 \mathrm{ft}$. Pkt. 5c.

\section{Antirrhinum or Snapdragon}

Without question one of the most desirable flowers for general garden culture. They come in a great variety of colors and are equally good for bouquets or for mass planting. They are biennials but can be handled as annuals also. When sown early inside, they bloom in July and then until frost. If covered slightly they will come through the winter nicely and bloom abundantly the second year. Medium tall strain, 18 to 20 inches. Finest mixed colors. Pkt. 5c, 1/4 oz. 20 c.

\section{Sweet Alyssum}

226 Little Gem Dwarf, neat, compact habit. Blooms from spring to frost. ExFlowers white, fragrant, completely covering the plants. Pkt. $5 \mathrm{c}, 1 / 4$ ounce $15 \mathrm{c}$, ounce $50 \mathrm{c}$.

227 Lilac Queen A decided acquisition. Just like delicate lilac. Very pretty. Pkt. 10c, $1 / 4$ oz. 30c.

\section{Bachielor's Button}

(Ragged Robin, Cornflower, or Blue Bottle.) One of the most popular and desirable of oldelor's Button and Baby's Breath make a most beautiful bouquet. Mixed colors, double and single. Pkt. 5c, $1 / 4$ oz. 15c.

229 Blanket Flower (Gaillardia.) Very showy annuals of easy culture. Blooms from early summer to frost. Flowers on long stems in orange, bronze, maroon and

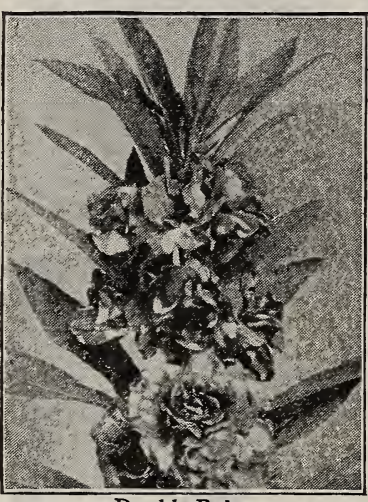

235

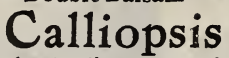

One of the leading plants for the flower garden, making a very showy border plant, producing flowers in nearly every shade of yellow, orange, crimson and brown, on long wiry stems, fine for cutting. Pkt. 5c.

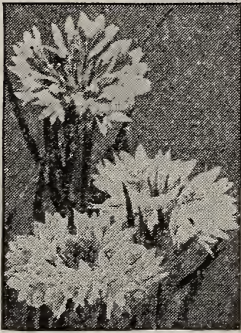

Bachelor's Button re of easy culture but fusion of wax-like flowers, in the most brillian rather tender. A fine mixture of Spotted Camellia and Rose flowered, doubles and singles. Pkt. 5 c, $1 / 4$ oz. 20 c.

\section{Calendula (Scotch Marigold)}

One of the best and showiest free-flowering hardy annuals, growing in any good garden soil, producing a fine effect, in beds or mixed borders, particularly bright in late fall, continuing in bloom from early summer until frost; valuable also for pot culture, blooming in winter and spring. Richest yellow and orange. Pkt. 5c, $1 / 2$ oz. 15c.

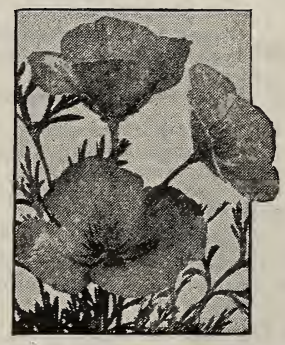

California Poppy

236 Cannas (Indian Shot.) Will bloom in 3 to 4 month with luxuriant foliage and brilliant flowers. Soak the seed in warm water until they become swollen then sow in light sandy soil about $1 / 2$ inch deep. Pkt. 10c, $1 / 2$ oz. 20 c.

\section{California Poppy or Eschscholtzia}

237 Eschscholtzia Mixed The state flower of California and one of the most atfinely cut foliage with the mass of bright colored flowers makes a most beautiful sight. Bloom from June until frost. Pkt. $5 \mathbf{c}, 1 / 1 / 4$ oz. $15 \mathrm{c}$.

238 New Geisha The flowers like little silken flags are exquisitely fluted the inside of in the sunlight like molten gold. Pkt. 10c, 1/4 oz. 25c. California Poppy (Persian Rug Mixture, Grandiflora Hybrids.) See Buttercup or Santa Barbara Poppy (Bush Eschscholtzia or lustration and description see No. 14 on page 5. Good for cut flowers.

\section{Candytuft}

One of our most useful and popular annuals. Completely covered all summer with clusters of flowers that are well 233 Giant Hyacinth Very large, bold spikes of

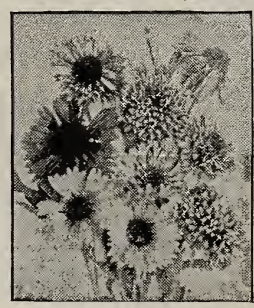
$10 \mathrm{c}, 1 / 4$ oz. $25 \mathrm{c}$.

234 Mixed Including all 5c, $1 / 4$ oz. 15 c.

Centaurea (Sw e e t See No. 10 on page 4.

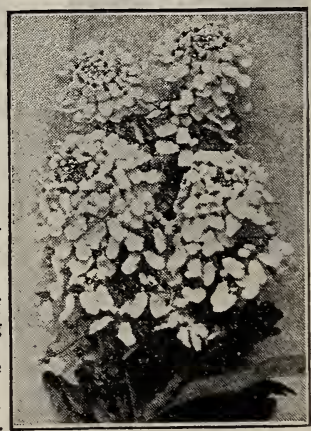

Gt. Hyacinth Candytuft 


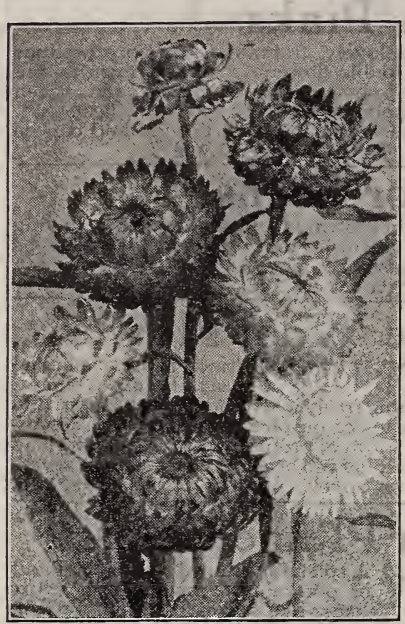

Helichrysum

\section{Four O'Clock}

254 Marvel of Peru One of the most popular and desirable annuals, the lawn and garden, or along driveways. Produces a fine for hedges between ounce of seed for a nice, long row. Pkt. (50 seeds) 5c, ounce pkg. 20c.

\section{Kochia or Fire Bush} 255 The New Giant (Summer Cypress, A charming and most effective decorative plant, with a habit much resembling one of the compact evergreen shrubs. It has a light grass-green feathery foliage, which changes as the summer advances to a rich crimson. The plants may be grown as single
specimens, or as an ornamental hedge. Pkt. $\mathbf{5 c}, 1 / 4$ ounce 15c.

\section{Larkspur}

256 Annual Quick-growing, free-flowering tered spikes of beatitiful flowers in greatest profusion. Splendid for the old-fashioned flower or shrub border. A splendid mixture, including Emperor, Hyacinth Flowered, Dwarf Rocket, Candelabra, etc. Pkt. $5 c, 1 / 4$ ounce 20 c.

\section{Nigella}

Love-in-a-mist. Compact, free-flowering annuals with pretty white and light blue flowers nestled in the feathery
foliage, and curious seed-pods. Pkt. 5c.
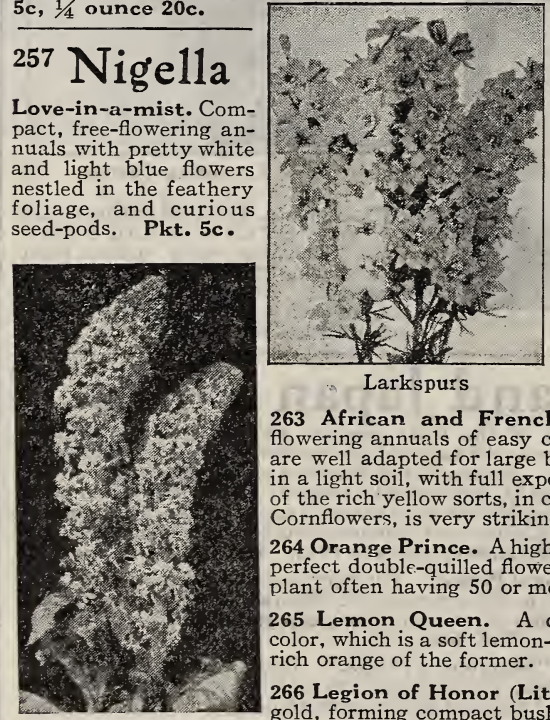

Larkspurs

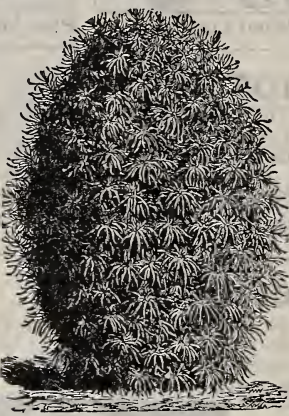

Fire Bush Marigolds Cornflowers, is very striking. Pkt. 5c, $1 / 4$ oz. 20c. rich orange of the former. Pkt. 10c.

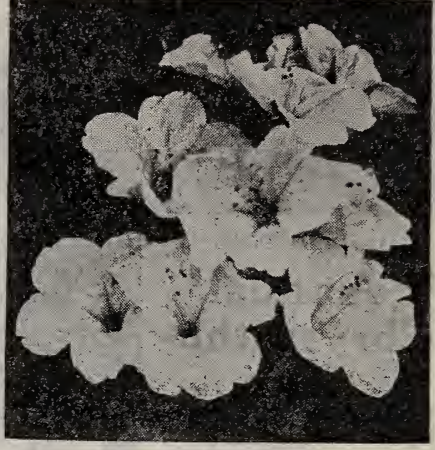

Four O'Clocks

Ice Plant

258 Mesembryanthemum. Very interesting annuals of low, trailing habit. The foliage and stems are covered with crystal-like formations that glisten in the sun. Nice for hanging baskets. Pkt. 5c.

Lobelia Crystal Palace. See No.13, Job's Tears

259 Coix Lachrymae. The seed is frequently used as an old-fashioned remedy for sore throat and teething babies. The seed is strung on a linen thread and worn around neck as a chain. Pkt. 5c, oz. 15c. 260 Dwarf Morning Glory Showy flowers like tall sorts but dwar plants-suitable for bedding or borders. Bloom all summer. Pkt. 5c; oz. 15c.

\section{${ }^{261}$ Mignonette (Reseda)}

This annual is an old-time favorite and with the introduction of new types it is one of the most generally grown flowers for fragrant bouquets, bedding plants and pot culture. For a continuous supply of bloom sow seed early in spring and again in mid-summer. Pkt. 5c, $1 / 2$ ounce 15 c. Mourning Bride ("Pin Cushion") 262 Scabiosa The Sweet Scabious of the old-time garden, fragrant, elegant for cutting. Many colors. $21 / 2$ feet high. Attracts many butterflies. Pkt. 5c.

Scabiosa, Azure Fairy. See front cover and No. 6 on page 4.

263 African and French Mixed. These are old favorite freeflowering annuals of easy culture; both are extremely effective and are well adapted for large beds or mixed borders; they succeed best in a light soil, with full exposure to the sun. A vase or bowl of any of the rich yellow sorts, in combination with a few blue Larkspurs or

264 Orange Prince. A high-bred tall-growing variety, bearing large, perfect double-quilled flowers of a rich deep golden-orange, a single plant often having 50 or more splendid flowers at once. Pkt. 10c.

265 Lemon Queen. A counterpart of Orange Prince except in color, which is a soft lemon-yellow, and forming a fine contrast to the

266 Legion of Honor (Little Brownie). A single-flowering Marigold, forming compact bushes 9 inches high. Iargely used for borMignonette ders. Flowers golden-yellow, with velvety-brown markings. Pkt. 5c.

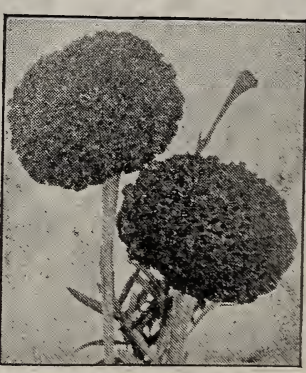

Marigolds, Orange Prince 


\section{Nasturtiums}

For summer display in large or small beds, nothing can surpass Nasturtiums. They start to bloom early and keep up a continuous display of bright colored flowers until hard frost in fall. Nasturtiums are much used for table decoration. Of the easiest culture, succeeding practically anywhere, in all soils.

Cut the Nasturtiums freely and they will bloom better. Do not pull them from the vines but snip them off.

Our various mixtures include the prettiest types you can buy.

267 Tall or Climbing For trailing lattice or arbors, or for covering old fences or unsightly places, also for vases, we consider the tall varieties most desirable. There is also a greater variety in colors, including the brilliant Lobbianum type. Mixture, including all types. Pkt. 5c, oz. 15c, $1 / 4$ lb. 40c, lb. $\$ 1.00$. 268 Tall Ivy Leaved A desirable Climbing Nasturtiums, having bright green Ivylike foliage, veined with white, with brilliant colored fringed flowers. Pkt. 5c; $1 / 2$ oz. 15c.

269 Tall Variegated Each leaf is irregularly with yellow, white and green, giving this plant a varied aspect. Pkt. 5c, $1 / 2$ oz. pkg. 15c.

Trailing Tom Pounce A Aistinct new strain. 270 Dwarf Mixed Nasturtiums ${ }_{\mathrm{cia}}^{\mathrm{S}} \mathrm{p}$ e desirable for bordering beds, walks or driveways, forming neat compact plants a foot across. Always in bloom from June to October. A splendid mixture comprising many varieties and colors. Pkt. 5c, oz. 15c, $1 / 4$ lb. 40c, lb. $\$ 1.00$.

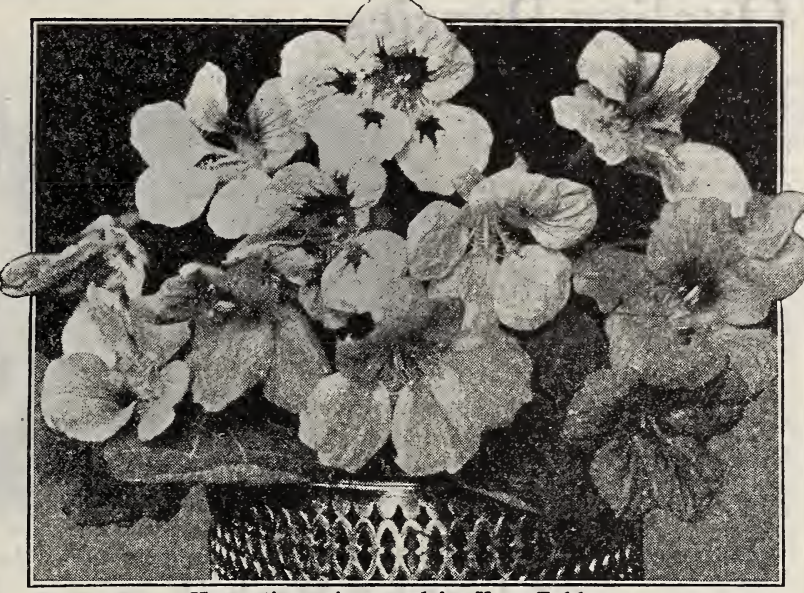

Nasturtiums Arranged for Your Table

271 Lilliput Baby Dwarf Queen of Holland Compact little plants with very dark green flowers in colors pale yellow to deep purple-unsurpassed for low, even borders. Pkt. 8c, $1 / 2$ oz. 15 c.

272 Fancy Leaved Dwarf Mixed Also very dwarf compact plants but the foliage is distinct and curious-variegated and marbled silvery white-and including the waved emerald green leaves. Flowers are vivid yellows, reds, orange, etc. Very showy. Pkt. 8c, oz. 20c.

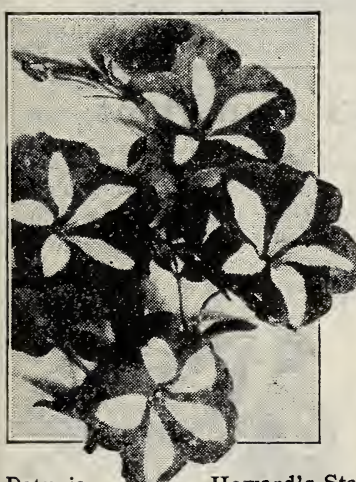

Petunia

278 Howard's Star (I mproved). Over a background of velvety crimson maroon are laid the paths of snowy white. The effect is a brilliant star clearly defined. Not all the flowers show the five points but all give the rich color combination. The illustration is of
our improved strain. Pkt.10c, $1 / 8$ our improve
oz. $40 \mathrm{c}$.

273 Nasturtium Collection One packet each of the above seven

\section{Beautiful Petunias}

For freedom of bloom, variety of color and effectiveness these have no equals. If only little care is bestowed upon them, Petunias will produce their handsome, sweet-scented flowers in their delicate and gorgeous colors all summer.

Blue Balcony Queen Illustrated on front cover and fully described on Giants of California The largest, most gorgeous'Petunias grown. Full Giants of California description, page 5 . See No. 15 . 274 Rosy Morn Imagine the rosy hue of the sky at sunrise and you have Rosy

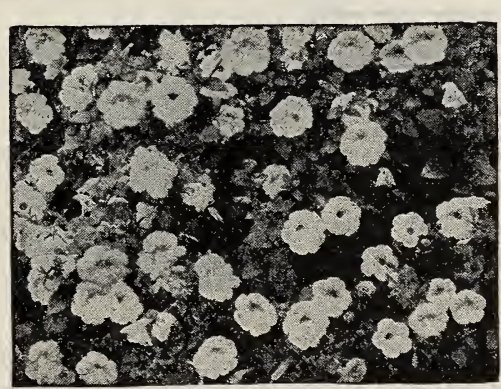

Snowball Petunia to its beauty. The plants are bushy and compact, so well adapted for bedding - and your bed will be a sheet of rose pink bloom all summer. Pkt. 10c, $1 / 8$ oz. 50c.

275 Snowball Another dwarf with flowers white as snow. Plant this as a border with darker shades and the effect is charming. Pkt. 10c, $1 / 8$ oz. 40c 276 Dwarf Inimitable Mixed. Makes a gorgeous bed resplendent all summer with dark shades strikingly blotched and striped white. Pkt. 10c, $1 / 8$ oz. 40c.

277 Hybrida Mixed

Pleasing shades run riot in this mixture and seemingly no matter what the conditions they are always in bloom Pkt. 5c, $1 / 8$ oz. 25c.

\section{Annual Phlox}

This splendid genus of plants is unrivaled for richness of color, profusion of bloom, length of duration of bloom and general compactness, and whether in clumps or masses looks equally beautiful. It is one of the finest annuals in cultivation, and should occupy a prominent place in every garden.

279 Grandiflora Mixture We offer this popular strain only in finest varieties and colors. The large flowering type. Pkt. 5c, $1 / 4 \mathbf{~ o z}$. 25c. 280 Starred and Fringed This beautiful type is quite distinct. The tically fringed, really two distinct types. Many bright colors. Pkt. 10c. Two Fine Dwarf Phloxes Fireball scarlet and Snowball pure ding. See full description, Nos. 18 and 19 , page 5 .

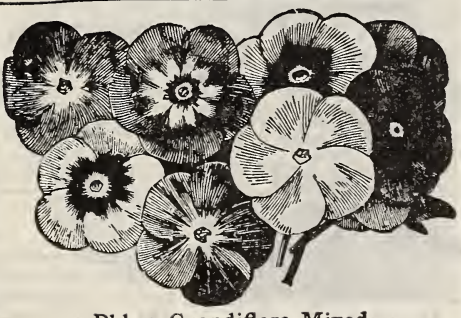

Phlox, Grandiflora Mixed 


\section{Quality Pansies}

Pansies are general favorites, too well known to require any description. We believe we can best serve our patrons by offering the seeds in only three grades, rather than to list them in separate named varieties. The following are the three grades or types:

\section{Bedding Mixture}

These are the popular saucy-faced beauties that everybody loves, comprising the finest varieties in all colors. Just what you want for a pretty bed. You will be delighted with this mixture. Pkt. 5c, $1 / 8$ oz. 25c, oz. $\$ 1.50$.

282 Giant Trimardeau this is ular medium priced large flowering type. They are of vigorous compact growth, and are grown in forty or more named varieties.

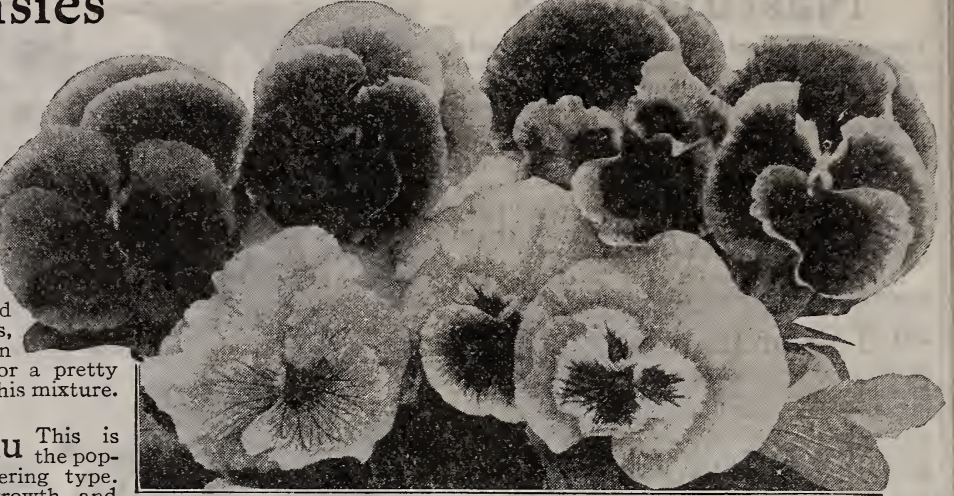

A Pretty Bouquet of Pansies from Our Bedding Mixture

\section{${ }^{283}$ Giant Exhibition Pansies}

The best that money can buy-In order that you may have the pleasure of growing some of the very best pansies in existence at a nominal expense we are searching each season-almost to the ends of the earth, among pansy specialists for the very best of their new strains. These many strains are mixed together and are what you receive in our Giant Exhibition

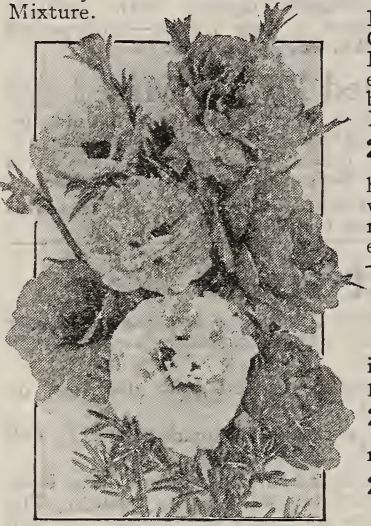

Double Portulaca

Included a re such high grade types as Special Paris Market, Masterpiece or Ruffled Giants, Cassiers Giants, Bugnots Superb Blotched, Phenomenal, Giant Striped and Mottled, Pure White, Black, Golden Giants and a dozen others. Grown on good soil you may expect to obtain flowers three and even four inches across, in all, colors too varied and Mixture. Pkt. 15c, 2 pkts. 25c, 5 pkts. 50c, $1 / 8$ oz. 90c, oz. $\$ 5.00$.

284 Pansy Violet (Viola or Tufted Pansy). Very desirable, free flowering plants habit of the Pansy with the hardy character of the Violet. They will do well in shady places where the ground is usually bare, for instance under the shade of shrubs. The plants do not run out like the common Pansy. Flowers not quite as large as Pansies, but produced in greatest profusion the entire season. Plants require protection over winter. Pkt. 10c, $1 / 8$ oz. 50c.

\section{Rose Moss Portulaca Sun Plant}

For brilliant coloring, nothing can excel a bed of Portulaca, with its silky flowers glistening in the sunlight. It is very easily grown and no bedding plant equals the Portulaca for places exposed to the hot sun of midsummer. Very pretty edgings for beds of taller plants. 285 Large Double As double as Roses, and comprising many brilliant colors. resembling small, fully open roses. Pkt. 10c.

286 Large Single Unsurpassed for carpet bedding where a brilliant effect

\section{Poppies}

\section{Plant Plenty} of Flowers

287 Double and Single Mixed $\underset{\text { brilliant }}{\mathrm{F}} \mathrm{i}$ dazzling effect plant lots of Poppies. Sow the seed very early in the spring, where they are to bloom, as they cannot be transplanted. For a long season of bloom make some later sowings. Pkt. 5c, $1 / 4$ oz. 10 c.

288 Shirley, Silk or Ghost The effect Poppies is what one would expect to see in a Chinese garden where vivid, glistening-still artistic, harmonizing colors hold sway. Orange, orange scarlet, soft salmon, rose and pink shades are painted on petals as delicate as Chinese silk. Do not miss these beauties. Pkt. 5c, 1/4 oz. 15c.

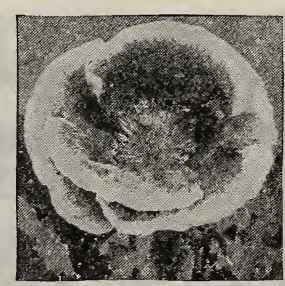

Shirley Poppy

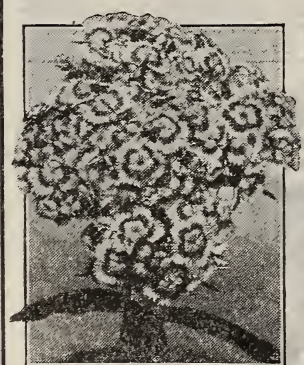

Annual Sweet William 289 Eldorado (New Double Shirley). The finest Popers burst out in the same brilliant shade as the singles-but
last as cut flowers or in the garden much longer. Pkt. 10c.

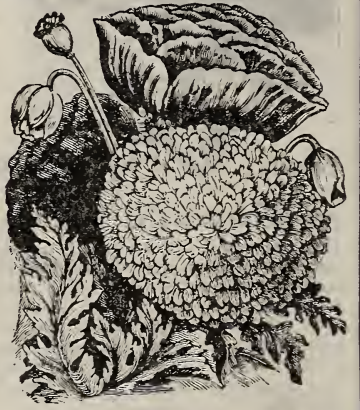

Double and Single Poppies 290 "Flanders Fields" The native single scarlet Poppy that covered the battlefields Flanders Fields of France and Belgium. Pkt. 5c, 1/8 oz. 15c

\section{Schizanthus or Butterfly Flower}

(Poor Man's Orchid). One of the most charming flowers for the garden in summer and for the house in winter. The plants are of compact branching growth $1 \frac{1 / 2}{2}$ to $2 \mathrm{ft}$. high, covered with multitude of small butterfly flowers of the most entrancing designs. Hardy annual. Pkt. 5c.

292 New Annual Sweet William

A valuable new annual blooming type of the popular Sweet William, originated by crossing the common Perennial variety with the Annual Japan Heddewigii Pink. " The flowers are much larger and are produced in clusters throughout the summer and autumn. Many beautiful colors mixed. Pkt. 10c, $1 / 8$ oz. 25c. 


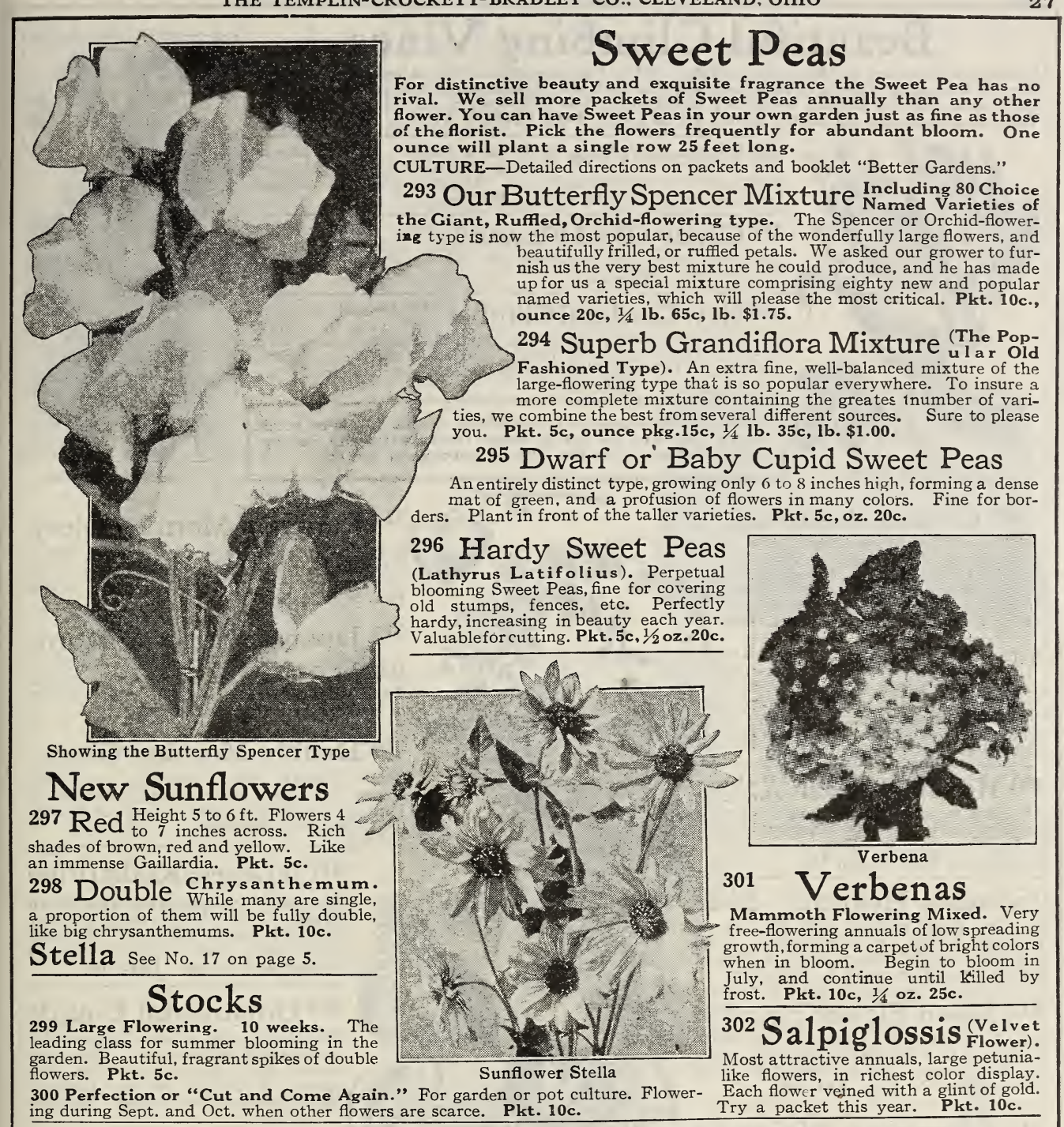

\section{Zinnias Always Please}

There is not another plant that does so well under any and all conditions. The brilliant flowers come all summer-almost bushels for cutting-and as many more left for garden display. The newer types hold a surprise in store for you.

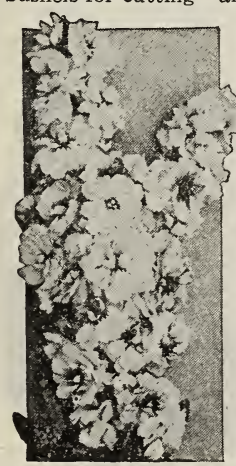

Stocks

Giant Novelty Sensational Dahlia, Cactus, on page 5 .

303 Giant Mixed Flowers like great big - Giant Maillantly painted balls over the old popular Zinnia. Plants 2 feet tall. Pkt. 10c, $1 / 1$ oz. 25c.

304 Elegans Mixed Produces excellent wide range of colors, and including many distinct types-Lilliputs, Pompons, Hybrids, etc. A great bargain. Pkt. 5c, $1 / 4$ oz. 15c.

305 Crested and Curled Flowers large, twisted and curved into most graceful forms. The colors comprise all the brilliant shades of the Zinnias. Pkt. 10c, 1/4 oz. 20c.

Red Riding Hood Intense scarlet buttons. Star Zinnias Entirely distinct from others.

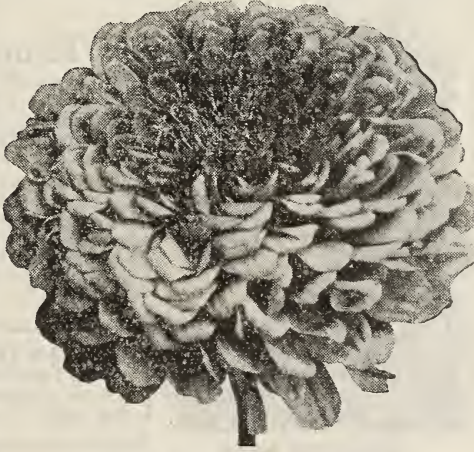

Giant Dahlia Flowered Zinnia 


\section{Beautiful Climbing Vines}

Nothing adds more to the attractiveness of the home grounds than a well chosen selection of Climbing Vines. They grow rapidly and are indispensable for covering arbors, old fences and for hiding unsightly buildings. The following varieties, except Kudzu Vine, are annuals, all easily grown from seed. FOR HARDY VINES, SEE PAGE 37.

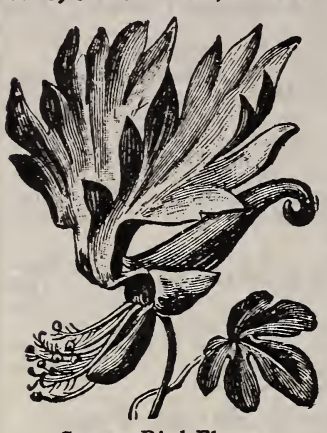

Canary Bird Flower

306 Balloon Vine (Love in a Puff). A rapid growing folioge, with inconspicuus flimbing vine, having pretty light green balloons, grow 8 to 10 feet high. Pkt. 5c.

307 Canary Bird Flower A pretty, rapid climbing canary-yellow flowers reminding you of a canary bird with wings half extended. Pkt. 5c.

308 New Cardinal Climber The New Hybrid Cyand valuable novelty. A strong, rapid climber with dark green fern-like, deeply laciniated foliage, and clusters of fiery cardinalred flowers $11 / 2$ inches in diameter. Thrives best in a warm, sunny situation. Pkt. 10c.

There is no excuse for unsightly places in your yard when you can so easily cover them with the pretty annual vines. See No. 321 at bottom of page.

\section{Cobaea Scandens}

A Mexican Vine of very rapid growth growing 15 to 20 feet high. Must not be planted outside until weather is permanently warm, Cultural instructions on each packet. Sometimes 310 Cypress Vine Delicate foliage, and pretty star-like flowers. Very desirable for small ornamenta trellises or wire supports. Scarlet and white varieties mixed. Height, 6 to 8 feet. Pkt. 5c.

311 Hyacinth Bean (Doliof extra rapid growth, making a dense and attractive screen, flowering freely in racemes or upright spikes not unlike Hyacinths. Pkt. 5c, oz. 15c.

Ipomea, Heavenly Blue A very rapid climber with clusters of immense bright sky-blue flowers. Very Order No. 20 on page 5. Pkt. 10c.

312 Moon Flower farge dense ing 20 to 30 feet. Immense pure white flowers 5 to 6 inches in diameter, open until the soil is warm. Pkt. 10c.

\section{Climbing Mixture}

You surely get your money's worth, as the price of one. Try a pkt. 5c.

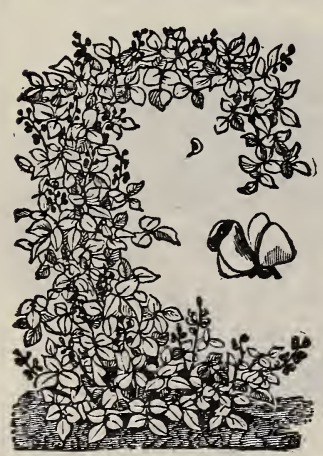

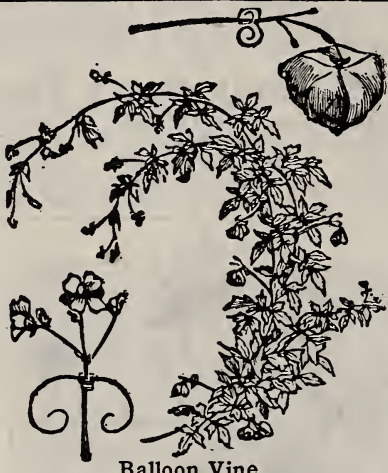

Balloon Vine

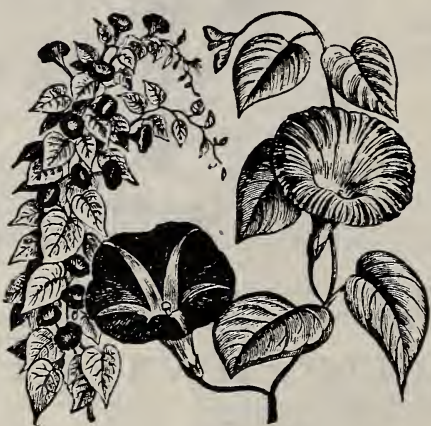

Common Morning Glory

314 Common Morning Glory Everybody should grow them. They thrive everywhere, climb rapidly, and bloom freely all summer. A mixture of many colors. 315 Japanese Imperial Morning Glory Unquestionably the handsomRapid climber, large foliage and immense flowers of rare beauty. Pkt. 5c, oz. 20c.

\section{Double Morning Glory}

(Snow Fairy). Rapid climbing vines that bloom quite early and continually until frost. Perfectly double pure white tassel-like flowers. Quite distinct. Pkt. 10c.

317 Japanese KudzuVine (Pueraria) "Jack - and - the-Bean Stalk." The fastest growing hardy climbing vine in existence. Perfectly hardy everywhere. Will climb 50 feet or more in a season. Pkt. 10c.

\section{Ornamental Gourds}

Very interesting rapid climbing vines for covering old fences, etc. The fruits are of many shapes and colors, and always a delight to the children. Many small varieties mixed. Pkt. 5c.

319 Thunbergia (Black Eyed Susan). An vine from Africa. Very elegant slender growing trellises, in vases, or trailing on the ground. Large single flowers, in white, yellow and orange, with distinct black eye. Bloom from July to October. Pkt. 10c. 320 Variegated Japanese Hop (Humulus). A beautiful rapid climbing vine for verandas, arbors or screens. Foliage mottled green and yellow. Once planted the seed will come up each spring without replanting. Very easy culture. Pkt. 10c.

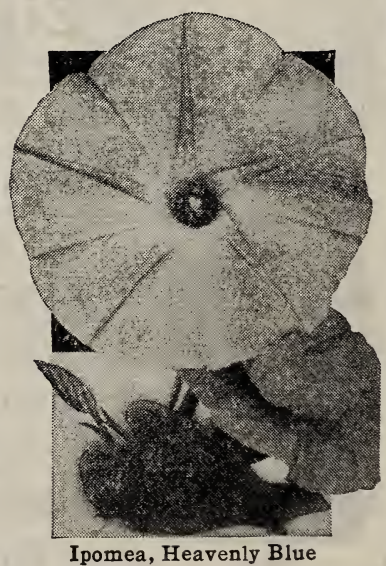


Old-Fashioned Kinds

\section{Hardy Garden Perennials}

Pretty New Types

ur Grandmothers' Gardens always contained an assortment of these old garden favorites. The following list contains about all of the popular easy-growing varieties. Why not start a hardy garden this year?

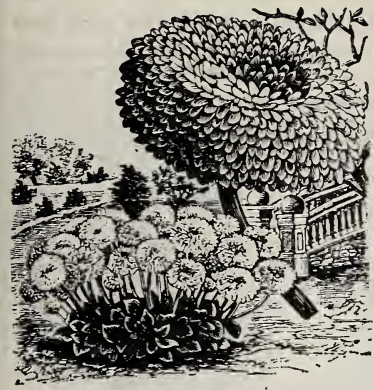

Double English Daisy

322 Aquilegia or Columbine Splendid hardy perennials, with colors. Choice mixed varieties, including the new long spurred hybrids. Will succeed in shady places. Pkt. 10c.

323 Campanula or Canterbury Bell Grand old-fashioned culture, and one of the most attractive seeds planted this year. Will grow into large plants that will bloom freely next year. Pkt. 10c.

324 Coreopsis Lanceolata Large single golden yellow fringed flowers, Bloom profusely in July and August. Perfectly hardy. Pkt. 5c.

325 Double English Daisies (Bellis Perennis). Low growing early sable for cool shady places. Seed started early in boxes should bloom the first year. Finest mixed varieties, including the large double Longfellow. Culture same as Pansies. Pkt. 10c.

326 Burbank's Shasta Daisy Strong, vigorous growing large clumps of bright, green foliage and a profusion of large white single flowers on long stems. Flowers 3 to 4 inches across, with large yellow disc. Bloom freely in July and August. Pkt. 10c.

Delphinium, Hardy Larkspur One of our most hardy perennials, producing immense spikes in various shades of blue, from July until killed by frost. Valuable for cutting. We list two strains, viz.: 327 Belladonna. Large spikes of beautiful clear turquoise-blue flowers that always attract attention. Bloom continually from July to frost. Pkt. 10c. 328 Gold Medal Hybrids. A choice mixture of English. Hybrids, ranging in color from pale lavender to
deep indigo-blue, including many double varieties. Pkt. 10c. 329 Digitalis or Foxglove Ta11, stately in white, pink, rose and mottled. Valuable for the background in the hardy border. Of easy culture, blooming the second year from seed. Pkt. 5c.

330 Hardy Gaillardia (Grandiflora). These in shades of yellow and red, are very attractive when in bloom from July to October; very easily grown. Pkt. 5c.

331 Hardy Baby's Breath (Gypsophila). Immense panicles of delicate white gauze-like flowers from June to August. Very desirable for mixing with
other cut flowers. Perfectly hardy and easily grown. Pkt. 10c.

332 Giant Mallow Marvels (Hibiscus). Forms large clumps, 4 to 5 feet high, with immense single flowers, 6 to 8 inches across. Perfectly hardy, easily grown from seed. A mixture of white, pink and crimson. Pkt. 10c.

How to Grow Perennials. The booklet "Better Gardens" free with $\$ 2.00$ orders gives easily followed directions.

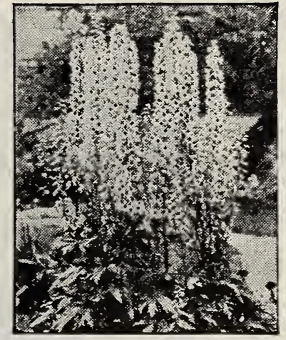

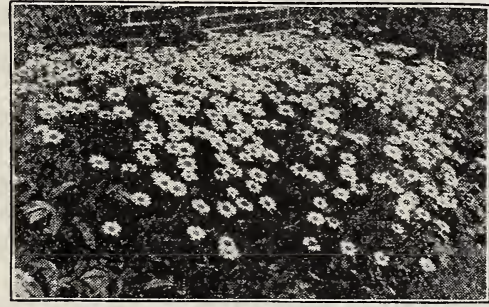

Burbank's Shasta Daisy 333Double Hollyhock Magnificent, tall stately plants, with immense spikes of perfectly double flowers in pink, white, crimbackground planting in the hardy border. Pkt. 10c.

334 Single Hollyhocks Many consider the single, large flowering varieties fully as beautiful as the double. We offer an please you. Pkt. 5c.

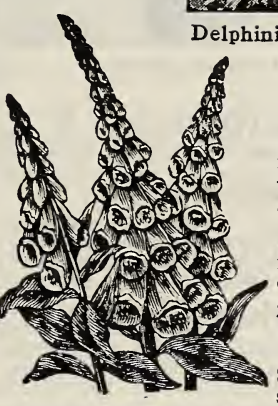

Digitalis or Foxglove 335 Myosotis or Forget-Me-Not The hardy Forget-me-not delights in a moist, shady location. The pretty delicate blue flowers are freely produced in June and July. One of our most satisfactory hardy perennials for shady places. Pkt. 10c.

336 Oriental Poppy $\begin{gathered}\mathrm{F} \circ \mathrm{r} \\ \mathrm{g} \text { or }-\end{gathered}$ geous display the Oriental Poppy has few rivals. Immense single glowing orange scarlet flowers with black blotch at base of petals. Pkt. 10c.

337 Hardy Garden Pinks Scotch, or Clove Pinks. Every garden should contain a few clumps of these hardy and easily grown. Pkt. 5c.

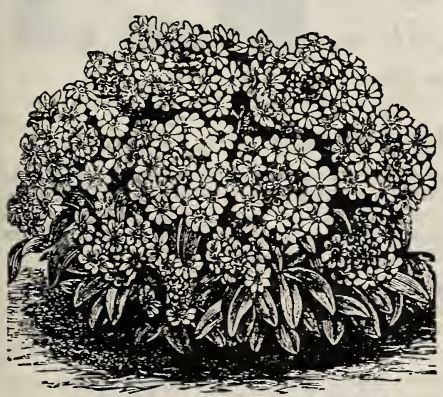

338 Stokesia (Stokes Aster)-Cyanea. A splendid perenborders. Its ease of cultivation makes it very popular. Blooms first year from seed. Showy deep lavender blue, aster-like flowers, produced in clustered heads June till late fall. Pkt. 10c.

339 Sweet William Well-known, old-fashioned, hardy Splendid for the hardy border and for massing. A gorgeous display when in bloom, comprising many brilliant colors. It is most satisfactory to grow young vigorous plants each year, and 340 Popular Old-Fashioned Hardy Collection Why not have an old-fashioned garden, such as we used to admire in our Grandmothers' garden? To help you start right we will supply one packet each of the above 18 varieties, worth $\$ 1.50$ for $\$ 1.00$.

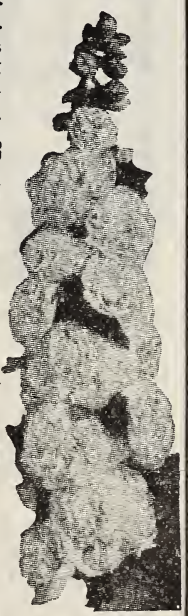

Double Hollyhocks 


\section{A MILLION GLADIOLUS BULBS}

You Should Grow Gladioli This Year. These Prices Within the Reach of Everybody

Gladioli are the most useful of all summer flowering bulbs, and are becoming more and more popular each year as new varieties are being introduced. They are so easily grown, and at our prices so inexpensive, that every

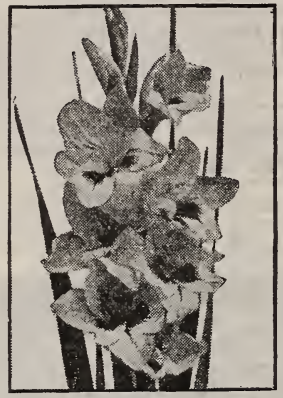

home garden should contain an assortment. Gladioli are one of our specialties. We now have in stock a million or more blooming size bulbs, all clean, healthy stock, ready to fill orders. All named bulbs will be $11 / 8$ to $1 \frac{1}{2}$ inches and up in diameter. Every bulb guaranteed to produce beautiful large spikes of flowers this year. We grew all the bulbs offered on this page, at our farms near Cleveland.

501 New Gladiolus Le Marechal Foch

One of the Newest Introductions

Named for the Great General of France and worthy of its great namesake, standing erect on tall spikes. Before opening, the buds are as beautiful pink as any rose-and as the great satiny petals unfold, they become that much loved Cameo pink, softly touched with a deeper shade. The coloring is delicate, yet seemingly almost alive as though a light was concealed deep in the throat. Marechal

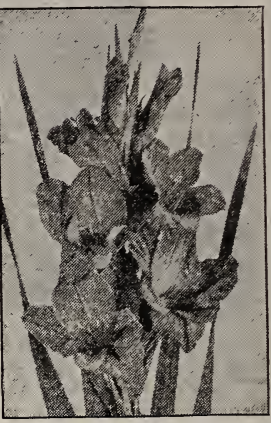

Mrs. Francis King

Mrs. Frank Pendleton

Twelve of the Most Popular Named Gladioli

For Illustrations in Natural Colors, See Back Cover

502 America Unquestionably the in existence. Immense spikes, color delicate peach-blossom pink. An old stand-by with florists and commercial growers. Each 6c, 12 for $50 c, 50$ for $\$ 1.75$.

503 Baron Hulot Very dark vioers medium size, on tall spikes. Entirely distinct in color. Each 10c, 6 for 40 c.

504 Cracker Jack of rich velvety dark red. Throat spotted with yellow. An early bloomer. All that its name implies. Each 6c, 12 for $50 c$, 50 for $\$ 1.75$. 505 Halley An extra early bloomer Color delicate salmon-pink. You will like the dainty pencilings in this variety. One of the best. Each 6 c, 12 for $50 c, 50$ for $\$ 1.75$.

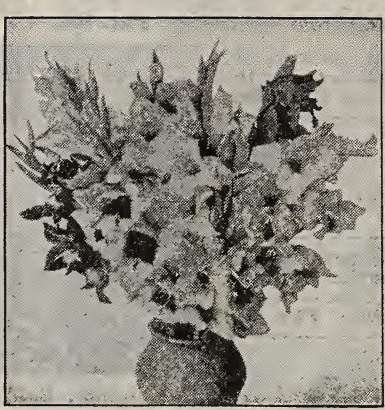

Vase of Gladioli 506 Mrs. Francis King A most beautiful flame-pink with vermilion shadings. Immense flowers on spikes, 3 to 4 feet high. A magnificent variety. Each 6c, 12 for 50 c, 50 for $\$ 1.75$. 507 Mrs. Frank Pendleton A peach-blossom pink, heavily blotched with blood red on lower petals. One of the most beautiful varieties. Highest award of American Gladiolus Society. Each 10c, 3 for 25 c, 12 for 90 c.

508 Panama which evokes words of praise wherever exhibited. Flower and spike very large. Color, lively pink. Each $7 \mathrm{c}, 12$ for 60 c, 50 for $\$ 2.00$.

509 Peace A grand white flower, of feathering on lower petals. Splendid tall, graceful spikes. Each 7c, 12 for 60 , $\mathbf{5 0}$ for $\$ \mathbf{2 . 0 0}$.

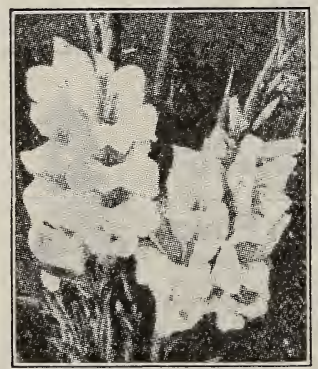

America

510 Primulinus Hybrids ${ }_{\text {South Africa }}$ A crossed with our popular varieties. Extra early, delicate shades of yellow, buff, fawn, primrose, etc., heretofore unknown in Gladioli. Each 6c, 12 for $50 c, 50$ for $\$ 1.75$.

511 Princepine A beautiful, distinct variety, color blotches on lower petals. Sometimes called the Amaryllis Gladiolus. Each $7 \mathrm{c}, 12$ for 60 c, 50 for $\$ 2.00$.

512 Queen Esther White ground, heavily streaked, flaked, and splashed with bright rose-purple. Lower petals blotched and streaked amaranth. Distinct in coloring and one of the first to bloom. Each 10c, 3 for 25 c, 12 for 90 c.

513 Schwaben The largest and strongest growing yelcanary yellow, shading to soft sulphur yellow. Lower petals marked with purple-scarlet. Each 10 c, 3 for 25 c, 12 for 90 c. 514 Set of 12 above named Gladioli for $75 \mathrm{c}$.

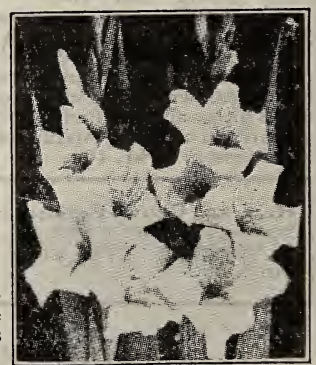

Peace

\section{Superfine Mixed Gladiolus Bulbs}

To those who want a choice assortment of Gladioli, at a nominal expense, and do not care for the named varieties, we recommend our Superfine Mixture, which we sell by the hundred thousands. This mixture is made up from the above and many other varieties which we grow under name. Also Groff's Hybrids, Lemoineii, Nancianus, Primulınus Hybrids, etc., which we grow in separate mixtures. A combined mixture that we do not hesitate to recommend. More than half of the Gladioli we sold last year were of this Superfine Mixture.

515 First Size In size from $1 \frac{1}{8}$ to $1 \frac{1}{2}$ inch and up 516 Second Size Size about $3 / 4$ to 1 inch in diameter. 515 First Size in diameter, every bulb guaranteed to produce a fine large spike of flowers this year. 12 for $\mathbf{4 5 c}$ 50 for $\$ 1.50,100$ for $\$ 2.75,500$ for $\$ 12.00$.

T Order No. 515 in quantities of 100 to 500. Plant at intervals from April to first of July, and you can Note have a continual supply of these grand flowers to decorate your home from July to October, at a nominal expense. 


\section{0,000 DAHLIA ROOTS}

In accordance with our established policy we have again selected just a few of the most distinctly beautiful varieties of recent introduction in the various types. During the blooming season we went carefully over several acres containing more than two hundred varieties then in bloom, and selected the following varieties, placing our order then for delivery in 1923, giving the grower time to produce these varieties in sufficient quantities to supply our growing demand. In quality our roots are the best that can be grown. Do not judge by the size as some varieties naturally grow twice as large as others.

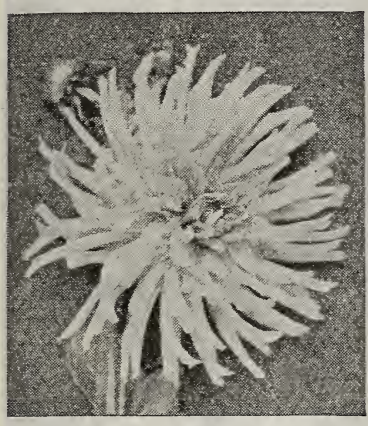

Peony Flowered Dahlias $521 \mathrm{D}$. Van Bystein Almost the color of the toned with silver. Large flowers 4 to 5 inches across. Each 20c, 3 for 50c.

522 Selma A beautiful, warm, rosy pink shading to Fine for cutting. Each 20 c, 3 for 50 c.

\section{Cactus Dahlias}

523 Bronze Beauty The shade of burnished sun or artificial light. A flower of rare beauty. Each 20c, 3 for $55 c$.

$\mathbf{5 2 4}$ Standard Bearer A vivid scarlet that Everybody will admire this most brilliant of all our Dahlias.

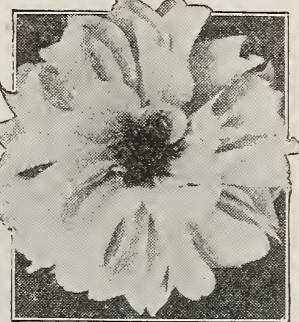

Peony Dahlia

Each 25c, 3 for 65 c. 525 Golden Gate A mass of shimmering gold. This is one of the new hybrid curved. Sure to please you. Each $20 \mathrm{c}, 3$ for $55 \mathrm{c}$. Cactus Dahlia

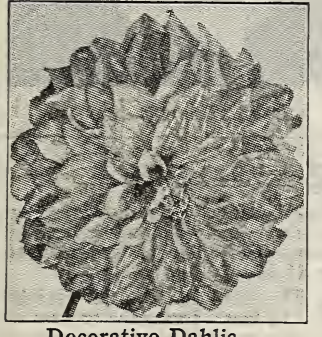

Decorative Dahlia

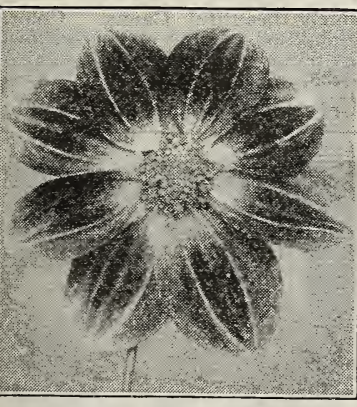

20th Century Dahlia 526 Countess of Malmesbury The delicate pink of peach blossoms. LightLong, straight quilled petals. True cactus type. Each 20 c, 3 for 55c.

\section{Decorative Dahlias}

527 American Beauty The same color as the and just as worthy, gorgeous flowers proudly lifting their heads high, on stiff stems. Each 20c, 3 for 55c.

528 Le Grand Manitou a marvelous flower, white, prettily spotted, striped and blotched reddish violet, with frequent solid self-colored flowers on the same plant. Enormous flowers as big as saucers. Each 25c, 3 for 60c.

529 Mrs. Roosevelt Remarkable both in size and blooms, with the deeper apple-blossom shades are beautiful beyond description. Belongs to the colossal class. Each 25c, 3 for 65 .

$530 \mathrm{Mrs}$. Hartong One of the best of the brand

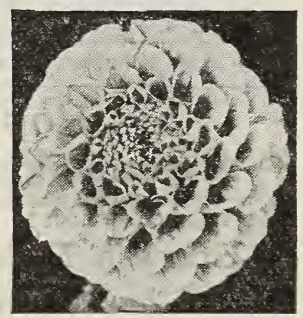

Show or Ball Dahlia Color a rich apricot-bronze, that glows in the sun. Each 25c, 3 for 65 c.

531 Mrs. Chas. Turner Best of the pure yellow decoratives. A grand the garden, or for cutting. Each 20c, 3 for 50 c.

\section{Show or Ball Dahlias}

532 Bird of Paradise Deep velvety red, each petal adding life and distinction to the flower. Good, long stems for cutting. Each $15 \mathrm{c}, 3$ for $40 \mathrm{c}$.

533 Caleb Powers Great large balls of white, softly pink. One of the most. beautiful show dahlias. Each 20c, 3 for 50 c.

534 Princess Victoria One of the best yellow show toyal name. Color clear primrose yellow. Each 15c, 3 for 40 c.

\section{Baby Pompon Dahlias}

535 Little Koerner A new bronze shade in pompons. Petals creamy yellow, tipped Little Koerner strawberry-red. Each 20c, 3 for 50 c.

536 Fireball or Vivid Blazing little balls of fiery-red. Always attract attention

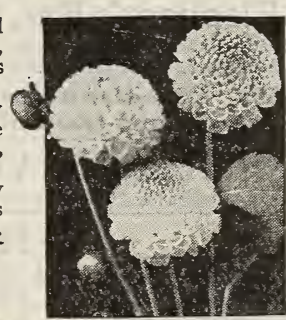

Pompon Dahlias
537 One each of the above sixteen varieties, all labeled, for $\$ 2.75$; two sets for $\$ 5.00$

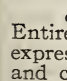

$$
\text { ; }
$$

$$
\text { t. }
$$




\section{LARGE FLOWERING CANNAS}

For beds on the lawn, where a tropical effect is desired, we know of no plant so satisfactory. They keep the yard and lawn ablaze with color. There are a hundred or more varieties in cultivation. We have selected just a few of the best and most distinct types and colors. We handle them only in dormant roots, which may easily be started in a box in a warm room, or in a hot bed. All have green foliage except number 546 .

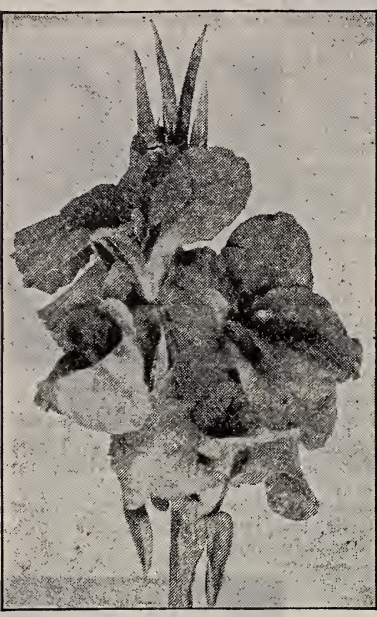

King Humbert Canna
Five Best Cannas

The following five Cannas are generally considered the best in existence.

545 City of Portland A g r a n d Magnificent heads of perfectly formed flowers. Color, bright, rosy, salmon-pink. The best pink to date. $4 \mathrm{ft}$. Each $20 \mathrm{c}, 12$ for $\$ 2.00$. $546 \mathrm{~K}$ ing Humbert This wonderful traction wherever grown. Dark bronze foliage and immense, bright orange-scarlet flowers. Height 4 feet. Each $15 \mathrm{c}, 12$ for $\$ 1.50$.

547 Queen Helen A sport from King Humbert, having plain green foliage and enormous flowers. Color, golden yellow, dotted and blotched bright-red. Height 4 feet. Each 15c, 12 for $\$ 1.50$.

548 The President The most senest flowered, most vigorous red canna in existence. Immense trusses of vivid scarlet. $41 / 2$ feet. Each 20c, 6 for $\$ 1.00$.

549 Wintzer's Colossal New giant chid flowering. Immense scarlet flowers, 6 inches across. Very free bloomer. Height 4 feet. Each $15 c, 12$ for $\$ 1.50$.

550 Set of Five Best Cannas for $65 c$

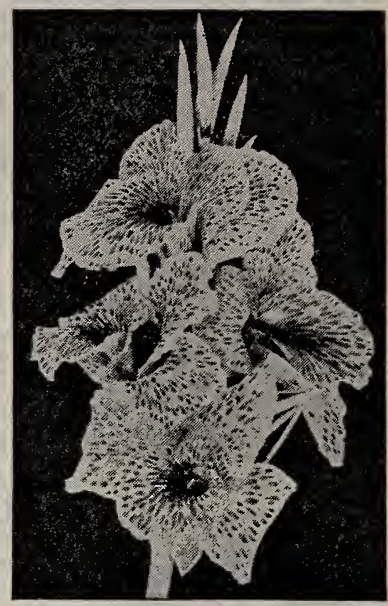

Queen Helen Canna

\section{Six Popular Large Flowering Bedding Cannas}

551 Allemania Extra large. Orchid-flowering, bright yellow border, dotted and mottled, with red. Height 5 feet. Each 10c, 12 for $\$ \mathbf{1 . 0 0}$.

552 Crimson Bedder Height $31 / 2$ feet. Green Large trusses of intense crimson flowers. One of the best. Largely used for bedding. Each 10c, 12 for $\$ 1.00$.

553 Florence Vaughan Height 41/2 feet. An ing particularly fine green foliage and large golden yellow flowers, freely dotted with crimson. Each 10c, 12 for $\$ 1.00$. 557 Set of 6 Bedding Cannas labeled for 60c
554 Golden Gate Height 4 feet. The flowers open richly rayed with orange-crimson and apricot, centering to the throat. Each 12c, 12 for $\$ 1.25$.

555 Madam Crozy The gilt-edge Canna. Height brilliant vermilion scarlet with narrow edge of golden yellow. Very popular. Each $10 \mathrm{c}, 12$ for $\$ \mathbf{1 . 0 0}$.

556 Venus An exceedingly beautiful Canna. Color, Large trusses of well formed flowers, green foliage, height 4 feet. Each 12c, 12 for $\$ 1.25$.

558 Set of 6 not labeled for 50c. 12 for $90 c$

Miscellaneous Summer Flowering Bulbs Elephant's Ear, Caladium One of the most effective tropical-1ike beds, or for planting singly or in masses on the lawn. Largely used in parks where their decorative value is appreciated. For best results, plant where they can be watered freely. 559 First size bulbs 20c each, 3 for $55 c, 12$ for $\$ 2.00$

560 Second-size bulbs $15 c$ each, 3 for $40 c, 12$ for $\$ 1.50$

561 Cinnamon Vine Well-known hardy climber: quick grower, with beautiful Vines will run 25 to 40 feet in a season. Each 10 c, 3 for 25 c.

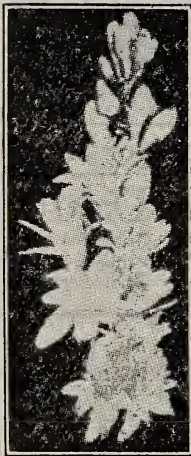

562 Hyacinth Candicans Yucca-like foliage and tall dant, fragrant flowers in mid-summer. Perfectly hardy, of very easy culture. Height 3 to 4 feet. Each 10c, 3 for 25c.

563 Madeira Vine One of the most satisfactory quick green foliage effect, glossy 20 feet or more. Winter the tubers in cellar, like potatoes. Each $10 c, 3$ for 25 c.

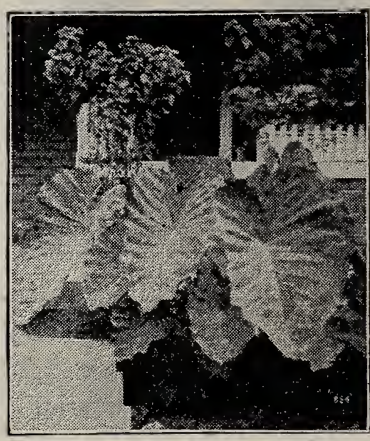

Elephant's Ear or Caladium

564 Oxalis (Summer Flowering "Shamrock"). These useful little plants are very effective in foliage about 1 foot high beds and are particularly valuable for edgings. They produce an unbroken row of

565 Zephyranthus ("Fairy Lily"). One of the prettiest and most easily grown bulbs for pot as Gladiolus. Pure white fragrant flowers. Each 10c, 3 for 25c.

\section{Double Dwarf Excelsior Pear1 Tuberoses}

No flower is more delightfully fragrant than the Tuberose. Of very easy culture. Plant the bulbs in May in the garden. Each bulb produces a spike of beautiful waxy-white flowers in August and September. Tuberoses succeed best in light sandy soil and full sunshine. Do not plant until the soil is permanently warm. For earlier flowers, start the bulbs in pots in a warm room and transplant in the garden in May.

Double Tuberose 566 Large first size blooming bulbs, 2 for $15 c, 6$ for 40 c, 12 for $75 c$ 


\section{HARDY HERBACEOUS ROOTS}

No home is complete without a well-selected assortment of hardy roots. They require so little attention and increase in size and beauty from year to year. Everything listed on this page is perfectly hardy, and our prices will be found very reasonable when quality is considered.

There are a number of Hardy Biennials, including Campanulas, Digitalis or Foxgloves, Hollyhocks, etc., that we do not list here, for the reason that it will be much less expensive, and we believe more satisfactory for you to grow the plants from seed, which you will find listed on page 29.

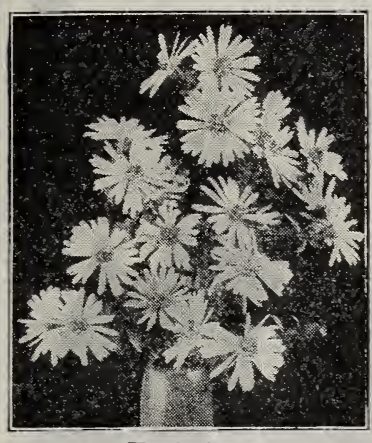

Hardy Aster

575 Hardy Aster Michaelmas Daisy. These are among the showiest of flowers during September and October, when most other hardy flowers are past. They grow freely in any soil, and require very little care. They are largely used to produce masses of foliage and flowers throughout the fall months. We offer them in three distinct colors, pure white, pink and lavender, but only in sets. The set of three colors, not labeled, for $35 \mathrm{c}$.

576 Aquilegia Col combine. The red flowers, gracefully hung on tall stems, always attract attention. Perfectly hardy, increasing in size from year to year. We list oniy the New Long-Spurred Hybrids, in finest mixed colors. Each 15c, 3 for 35c.

577 Hardy Baby's Breath Gypsophila Paniculata. Immense panicles of fine white gauze-like flowers in July and August. Very pretty with bouquets of other flowers. Should be in every garden. 2-year

578 Burbank's Shasta Daisy An improved type of Hardy Chryssingle glistening pure white flowers 3 to 4 inches across, on tall stems. A fine cut flower, and very showy in the garden. Hardy and of easy culture. Each $15 \mathrm{c}, 4$ for $50 \mathrm{c}$.

\section{Funkia or Day Lily}

579 Grandiflora. Large, pure white fragrant lily shaped flowers in August and September. Forms la rge clumps of big, glossy green foliage. Each 25c, 3 for 65 c.

580 Undulata Variegata. Graceful leaves having crimped or fluted creamy white edges. Splendidfor edging beds. Also very desirable as a pot plant during early spring. Each 20 c 3 for $50 \mathrm{c}, 12$ for $\$ 1.75$.

581 The two varieties for $40 \mathrm{c}$.
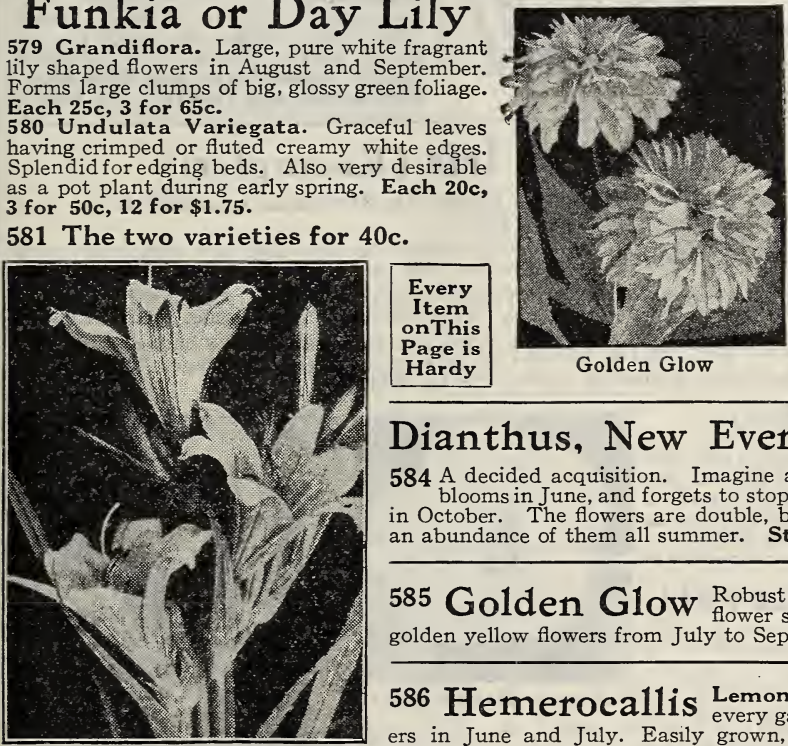

Page is

Hardy

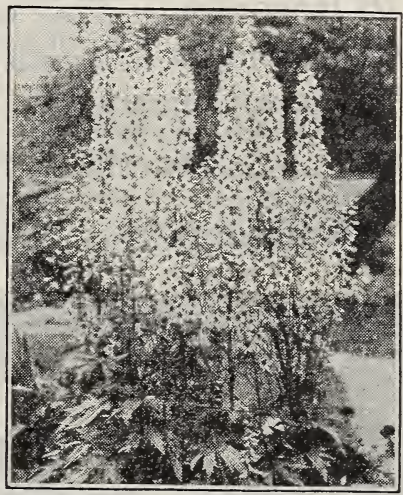

Hardy Larkspur Delphinium Hardy Larkspur 582 Delphinium Belladonna The beautiful "Belladonna" with its large spikes of clear sky-blue flowers always attracts attention. They bloom continually from July to frost. Perfectly hardy everywhere. See illustration, which is from a photograph. Strong blooming roots. Each 15 c, 3 for 40 c. 583 Gold Medal Hybrids Vigorous, free blooming, with flower spikes 2 feet long. Grand assortment of colors, ranging from light blue to purple. $20 \mathrm{c}, 3$ for $50 \mathrm{c}$.

Dianthus, New Everblooming Sweet William $584 \mathrm{~A}$ decided acquisition. Imagine a variety of the old-fashioned Sweet William that blooms in June, and forgets to stop blooming, but keeps right on until killed by frost in October. The flowers are double, brilliant deep red. Not an occasional flower, but an abundance of them all summer. Strong field grown plants each $30 \mathrm{c}$.

585 Golden Glow Robust hardy plants, with handsome foliage, and tall golden yellow flowers from July to September. Very desirable. Each 15c, 4 for 50 c.

586 Hemerocallis Lemon Lily. ers in June and July. Easily grown, requiring no
abundance of flowers each year. Each 15 c, 5 for 50 c.

Hemerocallis Lemon Lily $\mathrm{C}$

$$
\text { (1) }
$$

$$
\text { The }
$$$$
\text { ( }
$$ \\ }

Did
Chin
blend

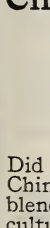

id you

These prices are unusually low, due to the fact that we now have a large stock for the first time since its introduction.

When you see this lily in bloom in your garden during July or early August, you will thank us for offering it to you.

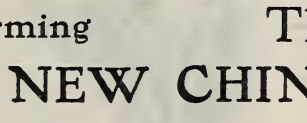

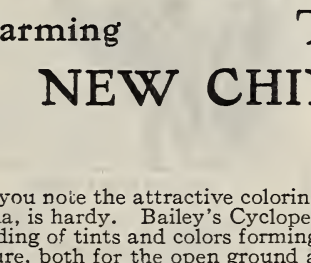




\section{Butterfly or Rainbow Iris \\ "Flag Iris," "Fleur-de-Lis" or "German Iris")}

Very popular old-fashioned, hardy garden favorites, requiring little attention. Splendid for permanent borders along the driveway or edge of shrubbery. The prices are so low that you will want lots of them. We have selected six of the most distinct and desirable varieties as described below. We know of no plant more easily grown and yet giving so much.

591 Canary Bird Very early. Self-colored pale canary yellow. 592 Florentina Alba Extra early, large, fragrant, pure white flowers, 593 Her Majesty New, standard rose-pink, falls bright crimson with darker 593 Her Majesty shadings. Each 10c, 3 for 25 c.

594 Honorabilis Standards golden yellow, falls richly veined ma-

595 Lohengrin New. Of gigantic size. Immense petals. Color deep violet596 Carge pure white flow-

$596 \mathrm{Mme}$. Chereau Large pure white flowed with light blue, very beautiful. Each $15 c, 3$ for 40 c. 597 Pallida Dalmatica Large fragrant ers on stems 4 feet high. Each 15 c, 3 for 40 c. 598 Parisensis Large deep purple, penciled 599 Set of 8 varieties, not labeled for $65 c$

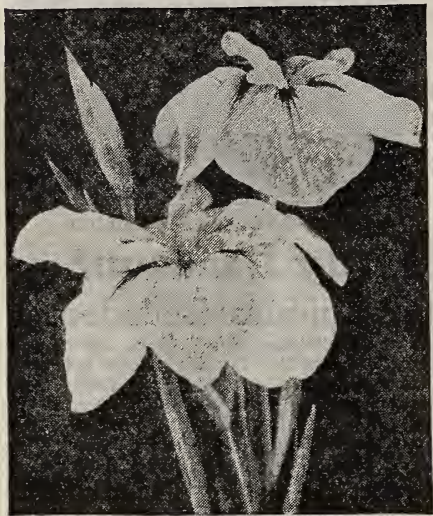

Japanese Iris

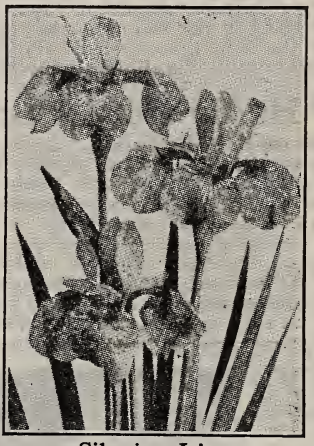

Siberian Iris

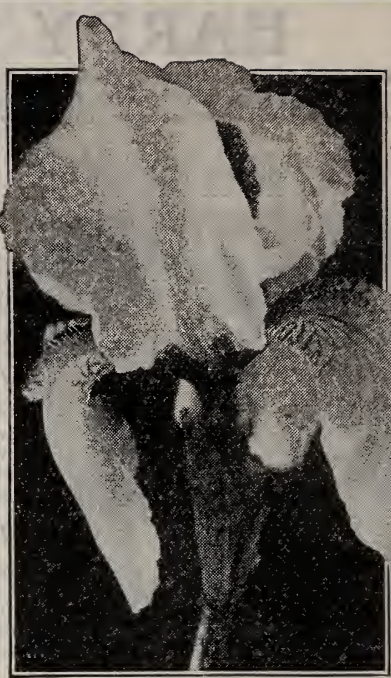

Butterfly or Rainbow Iris

\section{Siberian Iris}

Orientalis-The most delicate and graceful of all the hardy Iris. Forms large clumps with a multitude of tall flower spikes of the most beautiful flowers. Snow Queen and Yale Blue,

\section{Japanese Iris (Kaempferi)}

The largest of all the Iris family. Flowers 6 to 8 inches across on stiff stems. 3 to 4 feet high. Blooms throughout July.

601 Gold Bond Semi-double, six petals, very large pure snow-white with Gold Bond golden-yellow band and base. Each 25c, 6 for $\$ 1.25$. $602 \mathrm{M}$ ahogany Six large petals, brilliant mahogany red. Distinct from all Iahogany other Iris. Very attractive. Each 20c, 6 for $\$ 1.00$. 603 Purple and Gold Immense, semi-double, 6 to 8 inches across, rich 604 The three beautiful Japan Iris for $60 \mathrm{c}$

\section{Lily of the Valley}

Universally admired for their dainty little pure white bell shaped flowers and exquisite fragrance. Easily grown, perfectly hardy everywhere, preferring a moist shady location. We have 50,000 fine orders. 3 for $15 c, 12$ for $45 c, 50$ for $\$ 1.50,100$ for $\$ 2.75$.

\section{Meehan's Mallow Marvels}

\section{The most valuable acquisition in hardy Herbaceous plants in-} troduced in recent years. Forms large plants or clumps 5 to 6
feet high and 3 to 4 feet across, blooming profusely from July to late fall. Immense single flowers 6 to 8 inches across, in the Meehan's Mallow Marvel most beautiful colors, from white through various shades of pink and red to brilliant crimson. From 50 to 60 per cent will produce the brilliant red and crimson flowers. We however cannot supply them in separate colors.

606 Strong one year blooming roots, each $15 \mathrm{c}, 4$ for $50 \mathrm{c}$ 6072 year extra strong, each $35 c, 2$ for $60 c$

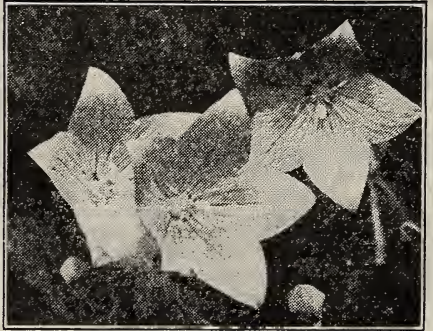

Platycodon or Chinese Bell Flower

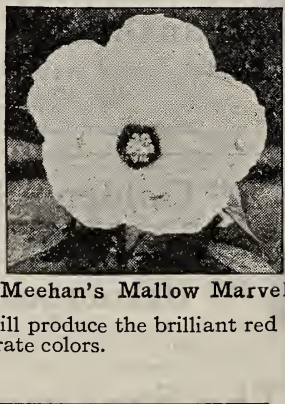

Platycodon (Balloon Flower) 608 Chinese Bell Flower

A splendid hardy perennial, having tuberous roots and forming bushes 2 feet high, with a profusion of pretty five petaled bell-shaped,

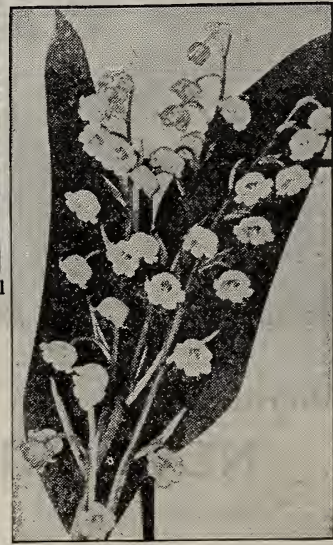

Lily of the Valley star-like flowers, $11 / 2$ to 2 inches across. The flower buds before opening resemble small balloons, hence the name. A desirable plant, of nominal cost, that should be in every garden. Two colors, pure white and dark blue, not labeled, for 25c.

609 Hardy Everlasting Sweet Peas (Lathyrus LatifoThey are perfectly hardy, increasing in beauty each year. Valuable for cutting. Three colors-White Pearl, Pink Beauty and Splendens Red. Strong roots. Set of three, one of each, not labeled, for $30 \mathrm{c}$ 


\section{BEAUTIFUL CHINESE PEONIES}

First of all in the list of hardy plants for size and beauty. As hardy as an oak, forming large clumps or bushes. Should be in every garden in the land. No matter how rich or poor you are, you cannot buy better varieties.

There are hundreds of named varieties and the list is still growing. It is useless to try to keep up with the procession. We have before us a peony specialist's catalog listing more than three hundred varieties. We believe our patrons will appreciate our efforts in selecting just a few varieties that are generally conceded to be the very best.

611 Duchess de Nemours Medium early, vigorous profuse bloomer. Color pure white with sulphur shadings, gradually changing to pure snow white. In all Peonies there is none more beautiful than this in the half open state. Upright branching habit. A splendid Peony. Each $35 c, 3$ for $\$ 1.00$.

612 Edulis Superba This might be called the Decoration Day on May 30th. Large, shaggy, flat crowns, of ten 6 to 7 inches across. Color bright mauve pink, with silvery reflex. More largely grown for

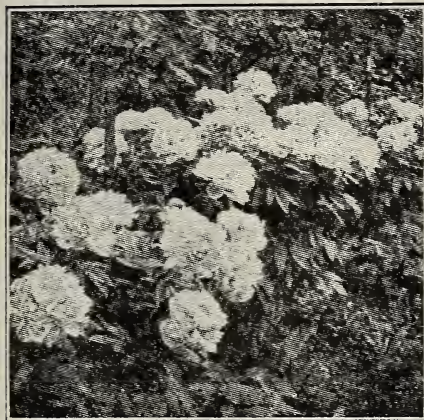

Clump of Festiva Maxima Peonies early cut flowers than any 3 for $\$ 1.10$. 613 Felix Crousse Generally considered the best red Peony in existence. Its large, globular, compactly built flowers are a rich, even, brilliant, dazzling ruby-red, free from the objectionable violet or purple shades. Medium or mid-season. A better red has not yet been discovered. Each 50c, 3 for $\$ 1.35$.

614 Festiva Maxima For seventy years this has stood at the head ered the Queen of all Peonies. It cor Often 7 to 8 inches across. Color pure snow white with an occasional clear carmine marking on center petals. Each 50c, 3 for $\$ 1.25$. 615 Monsieur Jules Elie Early mid-season. Peonies. Immense globular very full flowers. Color, glossy lilac-pink, shading to deep rose at the base, overlaid with a silvery sheen in the sunlight. The largest Peony in existence. Took both first and second prize at Boston Show last year. Each $\$ 1.00,3$ for $\$ 2.50$.

616 Set, one each of above five Peonies for $\$ 2.50$

617 Tritoma Pfitzeri (Red-hot Poker, Flame Flower or Torch Lily.) (The Ever Tritoma Pfiteri Blooming Flame Flower). Very handsome and showy plants keep a week or more after cutting. Succeed in any ordinary good garden soil. Bloom continually from July to October. Color rich orange scarlet. Hardy throughout the South, but require protection in North. Easily wintered over if buried in sand in cool cellar. Each 25c, 3 for 65 c.

618 Yucca Filamentosa (Adam's Needle). A tropical-looking plant; long, narrow leaves or four feet high, bearing large spikes of creamy-white, bell-shaped flowers that retain their beauty for a long time, 2 year roots $20 \mathrm{c}$ each, 3 for $50 \mathrm{c}$.

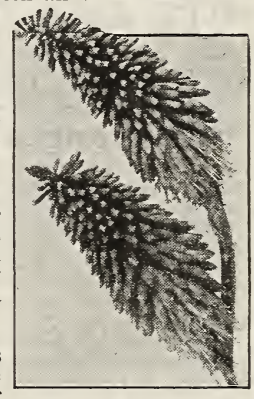

Tritoma Pfitzeri

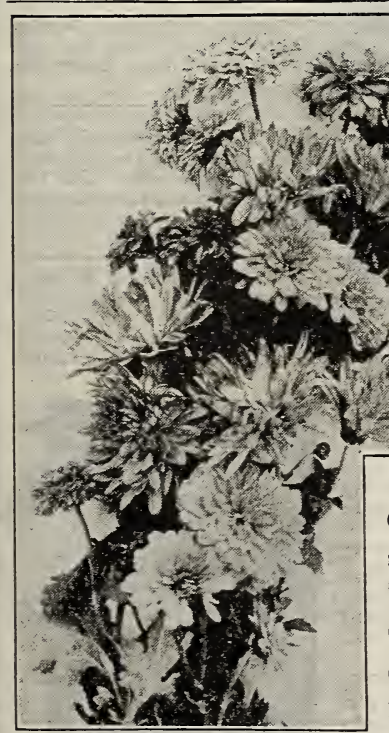

Spray of Hardy "Mums"

\section{Old-Fashioned Hardy Garden Chrysanthemums}

The well-known autumn flowers of our grandmothers'gardens that produce such an abundance of beautiful flowers at a time when they are most appreciated. In the following we have selected varieties that have proven hardy in the North with slight protection. Last season we sold about seventy-five thousand plants. This season we have added some desirable new varieties that make the collection more interesting, and have told our growers to be prepared to supply us one hundred thousand plants. Should be in every garden.

619 Glory of Seven Oaks One of the most valuable varieties in mid-summer and continues until killed by frost. Medium large, golden yellow, perfectly double flowers in greatest profusion. Each 15 c, 12 for $\$ 1.50$. 620 Autumn Glow American Beauty shade of rosy red. Medium bloomer. Each 12c, 12 for $\$ 1.25$.

621Eva A splendid new hardy "mum" forming neat compact clumps 12 to 15 12 for $\$ 1.25$.

622 Golden Climax Vigorous, compact habit. Double golden yellow pompon gets and are borne in great profusion. Very satisfactory. Each 12c, 12 for $\$ 1.25$. 623 Indian Chief Coppery red, shaded brilliant crimson. Very double and free bloomer. The best red. Each 12c, 12 for $\$ 1.25$. 624 Royal Pompon Neat compact plants. Covered with small brilliant

625 Victory Popular pure snowy white, like a big, double, white Aster. Very hardy. Each 12c, 12 for $\$ 1.25$.

626 The set of seven not labeled for $75 \mathrm{c}$ 


\section{HARDY FLOWERING SHRUBS}

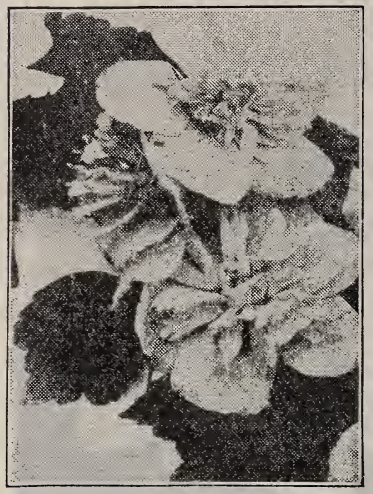

Double Althea

Every home should be surrounded by a carefully selected assortment of hardy shrubs. By this means a continual succession of flowers may be had throughout the season. Once established, they require little attention, increasing in size and effectiveness from year to year. The following list has been selected with great care and contains only varieties of real merit. The stock we offer is strong, one year, field grown, well rooted, dormant plants, 12 to 18 inches high. The size usually sent by mail, cut back, ready for planting.

Double Althea Rose of Sharon. Attractive hardy shrubs or small trees, high; also grown as flowering hedges. Large showy, double flowers in abundance from July to October.

631 Best double white. Each 15c. 632 Large double red. Each 15c.

633 Japanese Barberry A very desirable dwarf growing shrub for bordering followed by red berries. For ornamental hedges see opposite page. Each 15c, 5 for 50c.

\section{Buddleia Magnifica Butterfy Bush or} f the most desirable summer flowering shrubs, beginning to bloom in July, it continues until cut by severe frost. The flowers are of a pleasing shade of violet mauve, and are borne in dense cylindrical spikes. Succeeds everywhere and blooms freely the first season. In the North it dies down to the ground in wintcr forming a new bush each year 5 to 6 feet high. Each 25c, 3 for 60c.

635 Calycanthus Sweet Shrub. A favorite for a hundred years. The wood is scented, (a) foliage rich, and flowers of a rare chocolate color, having a peculiar, 636 Deutzia Pride of Rochester. Showy Japanese shrubs of the highest ornamental merit, flowering nature, renders them especially v
the branches in July. Each 15 c, 4 for 50 c.

637 Forsythia Golden Bells or Golden Chain. A foliage, and an abundance of golden yellow, drooping bell shaped flowers on long, graceful branches, hence the name. Often in bloom when the snow is flying. Each $15 \mathrm{c}, 4$ for $50 \mathrm{c}$.

638 Hydrangea Paniculata Grandiflora. This is tive, lasting in bloom for months. Without question the fines hardy shrub. Grows three to four feet high and is very bushy and compact. Blooms in July at a time when few other shrubs are in flower; the flowers remain until destroyed by frost. The flowers are pure white, changing to pink, and are borne in $60 \mathrm{c}, 12$ for $\$ 2.25$.

639 Hills of Snow Hydrangea Arborescens. The ful immense pure snow-white blooms from early June through August. A new variety that is fast gaining in popularity. One of the few shrubs that succeeds in partial shade. Will stand 20 degrees below zero. Each $30 c, 3$ for $75 c$.

$$
640
$$

\section{Bush Honeysuckle} Lonicera Tartarica. 4 to 6 feet. Neat habit, glossy green foliage, and pretty little pink flowers in pairs ("Twin Honeyries. Each 15c, 4 for 50 c.

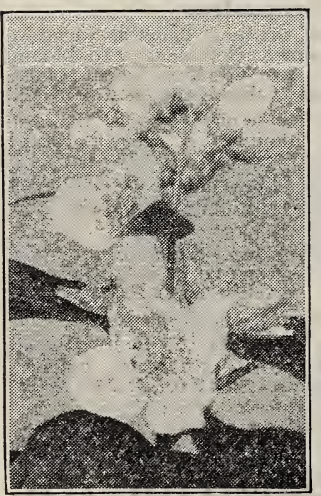

Mock Orange

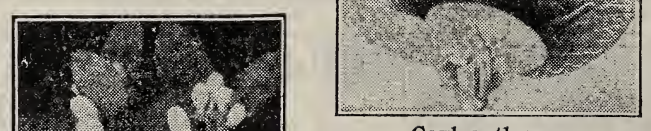

Caylcanthus

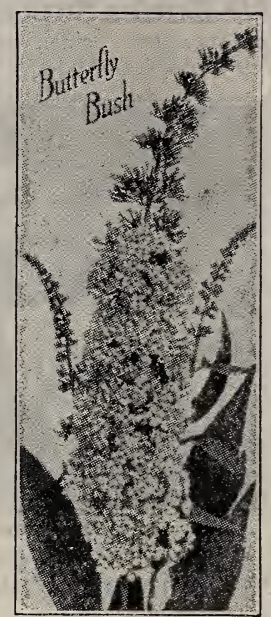

Buddleia

641 Persian

Lilac

Dwarf growing wit h slender branches and narrow leaves. Blooms same color, but much earlier and more freely than the common lilac. Each 20c, 3 for $50 c$.

642 Mock Orange Or Syringa (Philadelphus). One known shrubs. It seldom or never fails to bloom. The fragrant and beautiful waxy white flowers appear in great profusion in June. In shape and fragrance they resemble orange blossoms. Height 6 to 8 feet. Each 15c, 4 for 50c.

643 Sambucus Golden Elder. A strong growing for growing as single golden leaved ornamental shrub, shrubs. The best golden leaved shrub we know. Normal height 6 to 8 feet, but can be trimmed into a neat bush that always attracts atten.
tion. Each 25c, 3 for 60 .

Bush Honeysuckle

644 Snowball Viburnum Opulus. An old, wellshrub. Covered in May and June with great snow-white balls. Each 25 c, 3 for $65 c$.

645 Snowberry Symphoricarpos Racemosus. Neat growth, having pretty, small, pink flowers in June, followed by waxy-white berries throughout the summer, autumn, and early winter. Each $15 c, 4$ for 50 c.

646 Symphoricarpos Vulgaris In d i i n Similar to the Snowberry except that irs fruits are red, and that the smaller red berries cluster in thick ropes along the weighed-down stems. Each $15 c, 4$ for 50 c.

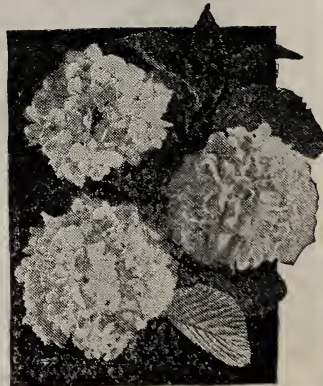

Snowballs 


\section{Four of the Best Spireas}

647 Spirea (Anthony Waterer). A very desirable dwarf growing; perpetual blooming shrub forming neat, round bushes two feet high, with large, flat sprays of

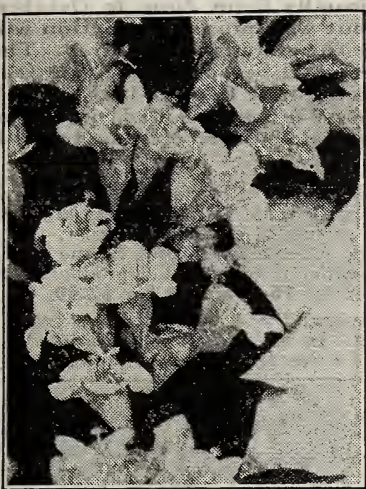
or planting around porches. Remove the flowers as they fade and they will bloom continually until frost. Each 20 c, 3 for 50 c, 12 for $\$ 1.75$.

648 Golden-Leaved Spirea (Opulifolia Foliage is of a bright golden color and finely shaded. This is one of the finest golden-leaved shrubs and a very desirable variety for the contrast it offers. Each 20c, 3 for $50 c, 12$ for $\$ 1.50$.

649 Spirea Thunbergii (Snow Garanese variety of medium size, with narrow, delicate leaves and a profusion of small, white flowers in early
summer. One of the best. Leaves narrow, bright green, turning in autumn to brilliant shades of orang

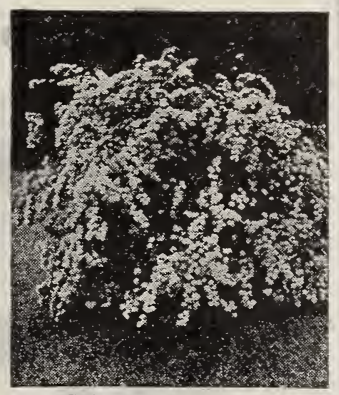

Spirea Van Houttei and scarlet. Grows 3 to 4 feet high. Each 20 c, 3 for 50 c, 12 for $\$ 1.50$. 650 Spirea Van Houttei One of the most beautiful and graceful ornalargely used in all landscape work. Will fit in anywhere where graceful effect is desired. For ornamental hedges, in clumps with other shrubs, for borders in front of porch, or as single specimens it is always satisfactory. Each $15 \mathrm{c}, 6$ for $75 \mathrm{c}, 12$ for $\$ 1.40$.

651 Weigelia, Rosea The most popular of all the Weigelias; a tall growing, vigorous sort with deep pink flowers in the greatest

Weigelia, Rosea abundance in June, and more sparsely at intervals throughout the summer. Erect
habit with good foliage. Height 5 to 6 feet. Strong plants. Each 20c, 3 for 50c.

\section{Ornamental Hedge Plants}

Ornamental hedges are fast replacing the old wood and iron fences for boundary lines. They add much to the appearance of the home, increasing in beauty, from year to year. Japanese Barberry and Privet are the most satisfactory varieties for this purpose. Don't try to have a full grown hedge at once by planting large 3 to 4 foot plants. One year old plants will be much more satisfactory and less expensive.

One year old plants 12 to 18 inches high, cut back to 5 or 6 inches, and planted alternately in a row thus, - will make a much better hedge than large plants in a single row. Plant the two rows 8 or 10 inches apart and the plants a foot apart in each row alternately. This will require twice as many plants as the hedge is to be feet in length. Plant two or three inches deeper than they were in the nursery, to encourage branching close to the ground. Cut back to 8 or 10 inches the second year before they start to grow, and to 15 or 18 inches in the third year. 50 or more at hundred rates.

Japanese Barberry Herberis Thunbergii). growing shrub, with spreading, deeply grooved, thorny branches and small, bright green, oval leaves that turn to brilliant shades of orange and yellow in autumn; the large bright red berries remain on the bushes throughout the winter, giving a cheery bit of color to the place in which it $652-1$ year 12 to 15 in.,2 or more branches, $\$ 6.00$ per 100

This is the variety approved by the United States Dept. of Agriculture. The only Barberry

653 California Privet (Ligustrum). No plant and deservedly into public favor. Vigorous growth, glossy dark green foliage until after Christmas. Almost evergreen. 1 year, 12 to 18 inches, 12 for $\$ 1.00,100$ for $\$ 6.00$.

654 Japanese Privet (I bota). Valuable new than California Privet, bright green foliage and small clusters of fragrant white flowers. Its great value is for hedges, being absolutely hardy everywhere, and may be trimmed to

Price: 1 year branched 12 to 18 inehes, 12 for $\$ 1.25,100$ for $\$ 8.00$.

Nothing adds more to the attractiveness of any home than a few well-selected hardy vines. For porches, arbors, etc., and for hiding outbuildings and unsightly places, they are indispensable. See page 28 for seed of quick growing annual Climbers.

655 Ampelopsis Veitchii (Japan or Boston Ivy). Popular hardy climbing vine that Strong 2 year $20 c, 3$ for $50 c, 12$ for $\$ 1.75$.

656 Ampelopsis Engelmanii A new type of Woodbine having shorter joints and walls, almost equal to Veitchii. Each $15 \mathrm{c}, 4$ for $50 \mathrm{c}$.

657 Chinese Matrimony Vine (Lycium). Vigorous growing, hardy climbing vine training to trellis, fence or wall. Pretty pink flowers from June to September, followed by showy red berries. Each 20c, 3 for 50c. $658 \mathrm{Clematis} \mathrm{(Paniculata} \mathrm{or} \mathrm{Snowbank).} \mathrm{Sweet-scented}$

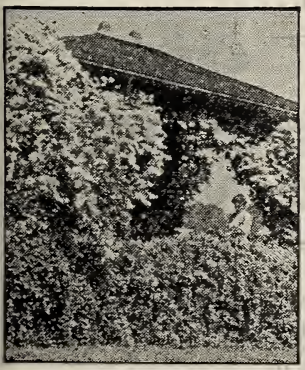

Clematis Paniculata

\section{Hardy Climbing Vines} tember with a mantle of pure snow-white fragrant flowers. Strong 1 year $20 \mathrm{c}, 3$ for $50 \mathrm{c}$.

659 Bignonia Radicans $\underset{\text { woody vine, with numerous roots }}{\text { (Trumpet Flower). A robust }}$ along its stems. Its orange scarlet, trumpet-shaped flowers cluster at the tip of the branches. Leaves light green. Will climb to great heights. Each 15c, 4 for 50c.

660 Honeysuckle (Hall's Japan). Very rapid climber.

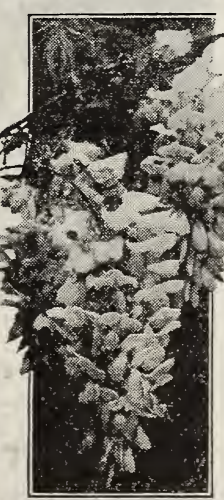

Wistaria flowers from June to August. A most satisfactory vine to plant. Strong plants $15 \mathrm{c}, 4$ for $50 \mathrm{c}$ 661 Honeysuckle (Coral or Scarlet Trumpet). Quite distinct from Hall's Japan. climber. Each 15c, 4 for 50 c.

662 Japanese Kudzu Vine (Pueraria). "Jack-and-the-Bean-Stalk." The Perfectly hardy anywhere. Will climb 50 feet or more in a season. Each $25 c, 3$ for 60 c. 663 Chinese Wistaria Hardy rapid-climbing vine, having large clusters of light in size and beauty each year. Each $25 c, 3$ for 60 c. 


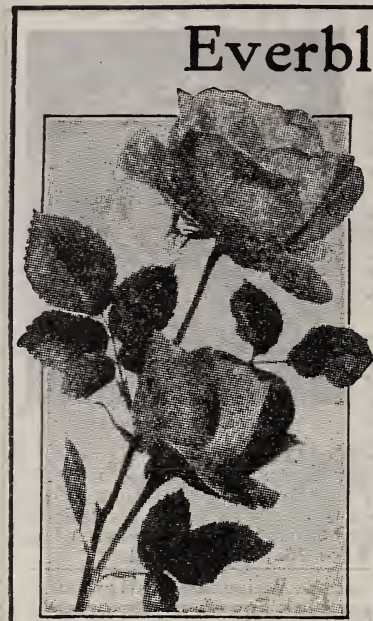

Gruss an Teplitz Rose

The great value of this class of roses is in their everblooming habit, producing their beautiful fragrant buds and roses continually from June to October. They are not absolutely hardy in the north, but with proper protection will winter over nicely, and will amply repay you for the extra labor required. The best plan in planting Hybrid Tea Roses is in prepared beds, three or four feet wide. Prepare the soil to a depth of two feet, and plant 15 to 18 inches apart Cultural instructions sent you with each order. We have selected six of the best varieties which we supply in strong 2 year field grown plants, that will bloom freely this year.

665 Gruss an Teplitz As a bedding Rose this is one of the finest. The color is It is very fragrant. The freest grower and the most profuse of any ever-bloomer. The mass of color produced is wonderful, and the foliage is extremely beautiful, all the young growth being a bronze-plum color. A queen among scarlet bedders. Will produce more flowers throughout the year than any other rose in existence. $75 \mathrm{c} \mathrm{each,} 3$ for $\$ \mathbf{2 . 0 0}$.

$666 \mathrm{~K}$ aiserin Augusta Victoria This splendid Rose should be in every col1ection. In color it is a soft pearly-white, tinted with just enough lemon in the center to relieve the white, remarkably fragrant, beautifully formed flowers on long, graceful stems; a
strong, free, healthy grower. 75 c each, 3 for $\$ 2.00$. 667 Madame Caroline Testout One of the most popular roses in its class and undoubtedly one of the best for outdoor culture. Should be in every garden. Immense, large, clear pink flowers, full and double, beautiful buds. Very hardy, blooms very freely, almost always in bloom. $75 \mathrm{c}$ each, 3 for $\$ 2.00$.

668 Ophelia A variety which has made such a record for itself that qualifies it (o be classed with the very best; a Rose that is admired by every most pleasing delicate tint of salmon-flesh, shaded with rose. $75 \mathrm{c} \mathrm{each,} 3$ for $\$ 2.00$. 669 Sunburst (Jos. Pernet-Ducher 1912). Flower superb cadmium yellow, with orange yellow center, large, fairly full, cupped form, the Growth very vigorne singly. on long, stout stems are flowering. This magnificent giant yellow rose has created sensation wherever shown; it stands head and shoulders above all other sorts of its color. Ranks with all other forcing roses in value $\mathbf{7 5 c}$ each,3 for $\$ 2.00$. 670 Red Radiance An ideal bedding Rose of American origin that conmost unfavorable hot summer weather when frequently many other varieties fail; in color a brilliant cerise-red with yellow shadings at the base of the petals; truly a Rose for every garden. $75 \mathrm{c} \mathrm{each,} 3$ for $\$ 2.00$.

Above All Two-Year, Field Grown Roses

671 The set of six Everblooming Hybrid Tea Roses for $\$ 4.00$.

\section{Pot Grown Hybrid Tea Roses}

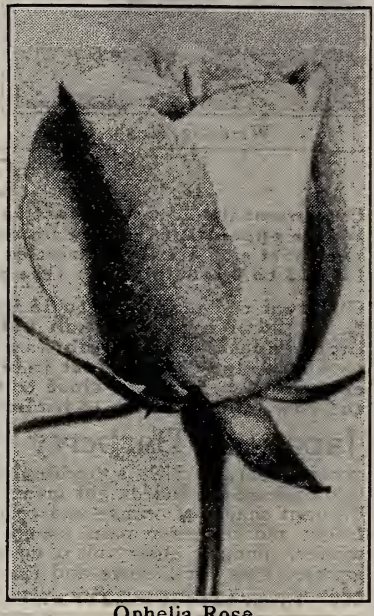

For the accommodation of those who wish to order a smaller, less expensive grade of Hybrid Tea Roses we are prepared to supply the following set in well established 1 year old plants, 6 to 8 inches high from $21 / 4$-inch pots. There are millions of these little roses sold annually that give general satisfaction. Instructions for planting and for winter protection will accompany each order.

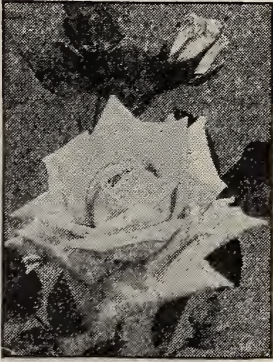

Hybrid Tea Rose
Bessie Brown-Very large; double flowers, color creamy-white, outer petals edged delicate rose, very fragrant. A magnificent Rose. Columbia-A grand big Rose often measuring 4 inches across. Color a true light pink, deepening as it opens to rose pink.

Etoile de France--The gold medal Rose of France. Color a clear velvet crimson, a good grower and free bloomer.

Helen Gambier-Deep rich golden yellow. Fine, large buds. A vigorous free bloomer. Changes of color as season advances are wonderful.
Killarney or Irish Bea uty-A grand Hybrid Tea Rose. Beautiful long pointed buds. Color an exquisite shell pink, base of petals silvery white. One of the most popular garden Roses.

Miss Helen Gould-Color warm rosy-crimson or American Beauty red, long pointed buds, and full double flowers. A splendid Rose in every respect.

White Maman Cochet-A grand hardy Tea Rose, very large double pure white flowers, and lovely long pointed buds. A strong grower and true bloomer.

\section{Sold only in Full Sets. The Seven for $\$ 1.00$}

\section{Everblooming Hardy Cluster Rose}

673 Baby Rambler Entirely distinct from all other Roses. Neat, dwarf, compact, perfectly double flowers in large clusters. Color brilliant crimson. Perfectly hardy, retaining its glossy green foliage all summer. Grows about 18 inches high. One of the finest ever introduced. 2-year field grown plant. Don't confuse this with the Climbing Ramblers. We have seen a number of beautiful hedges of this variety. Each $35 c, 3$ for $\$ 1.00$.

\section{Old-Fashioned Hardy Garden Rose}

674 Madam Plantier An old time favorite of our grandmothers' days. Completely 674 Madam Plantier covered in June with snow-white, fragrant, perfectly double roses. Sure to please you. Largely used for cemetery planting. Once planted will increase in size and beauty from year to year, requiring little attention. Each $25 \mathrm{c}, 5$ for $\$ 1.00$.

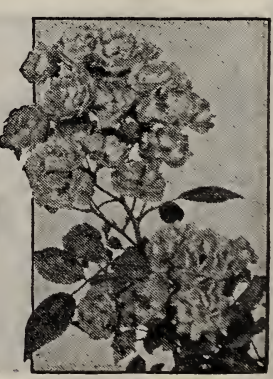

Baby Rambler 


\section{Hardy Hybrid Perpetual Roses}

These are the beautiful "June Roses" so universally popular. They are the largest and richest in colors of These are the beautfuctly hardy everywhere. There are a hundred or more varieties, but in accordance with all Rostablished policy we have selected only four of the best varieties. They will be strong 2 -year old field grown plants that should bloom this season. Tops cut back ready to plant.

676 Frau Karl Druschki (Everblooming White American the grandest hardy pure white Roses ever introduced. Makes splendid buds and immense flowers 4 to 5 inches across, perfectly double and delightfully fragrant, large thick petals, very double and handsome. Bright, shining green leaves, elegantly veined; a healthy vigorous grower, entirely hardy and a constant and abundant bloomer. Each $60 \mathrm{c}, 3$ for $\$ 1.50$.

677 General Tacqueminot A rich, velvety crimson, changing best known of all hybrid perpetuals, and is without rival in fragrance and richness of color. As easy of cultivation as many of the more common varieti
and hardy. Does well anywhere and blooms freely. Each $\mathbf{5 0 c}, 3$ for $\$ 1.25$.

678 Mrs. John Laing Flower soft pink, shaded lilac, large, full, Growth vigorous, early and late flowering. First-class in every respect. Each $40 c, 3$ for $\$ 1.00$.

679 Paul Neyron the largest Rose in cultivation, sometimes called

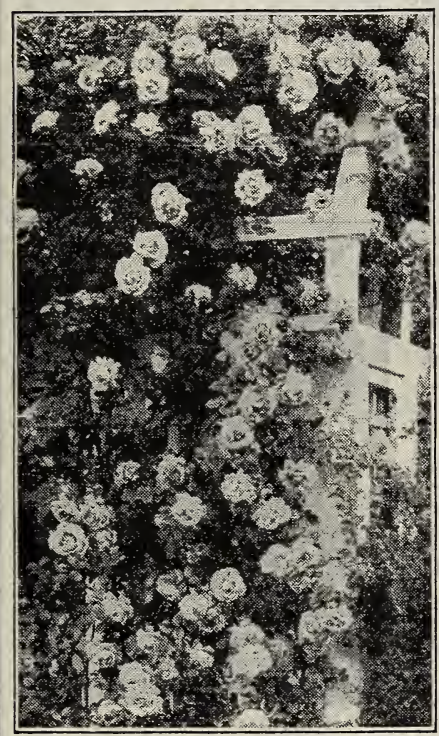

Climbing American Beauty Roses Flowers are very double and full, delightfully fragrant. The plant makes a strong, healthy growth and has clear, glossy foliage. Blooms almost continuously June until late 680 The Four Best $\mathrm{Hy}-$ brid Perpetual Roses for $\$ 1.85$

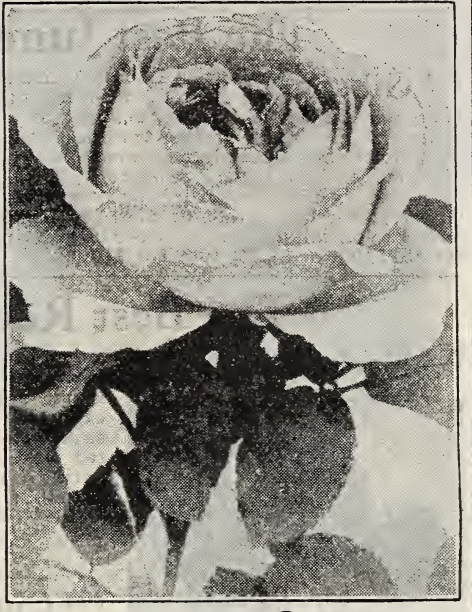

Paul Neyron Rose

\section{ThreeBeautiful Hardy Climbing Roses}

\section{Strong Dormant Field Grown Blooming Size Plants}

681 Climbing American Beauty ${ }_{\text {merit. Cross between an }}^{\text {grand novelty of great }}$ American Beauty and an unnamed seedling; color rosy crimson, similar to its popular parent, and with same exquisite fragrance, a quality rarely found in climbing roses. Strong growth, making shoots 10 to 15 feet in one season. Flowers are from 3 to 4 inches in diameter, of fine form, and are produced in a great profusion in May and June. Each 40c, 3 for $\$ 1.00$.

682 Doctor Van Fleet One of the newer type of climbers which comthe tender sorts of Tea and Noisette class. This variety shows a mass of beautiful clustered buds, which open out into large, shapely flowers; delicate flesh white. An admirable cutting variety with stems 12 to 18 inches long. Each 50c, 3 for $\$$ i.25. 683 Tausendschon (Thousand Beauties). A rapid growing, almost Polyantha and Tea parentage. Its innumerable flower clusters make a pretty show in June and July; first, the soft pink of deepening to a bright $\mathbf{3}$ for $\$ 1.00$.

684 Set of 3 Above Varieties for $\$ 1.10$

\section{Three Perkins Hardy Climbing Roses}

Do you remember the beautiful climbing Roses that you admired so much when you saw them in bloom last June, and didn' $t$ you promise yourself that you would order a set this Spring for your own home? The Roses you admired were the pink, white and crimson Perkins. These Perkins Roses are popular because they are so easily grown, and so beautiful when in bloom. We have 20,000 strong field grown plants ready to fill your order 3 .

685 Dorothy Perkins The original "Perkins" Rose, and date. A vigorous, rapid climber with glossy green foliage and clusters of clear shell-pink double flowers. Each 30c, 4 for $\$ 1.00$.

686 Excelsa (Crimson Perkins). Brilliant crimson-maroon to 40 flowers. Better in every respect than the popular Crimson Rambler. Glossy green foliage not subject to mildew. The best red climbing rose. Each 30c, 4 for $\$ 1.00$.

687 White Dorothy This beatiful rose is the counterpart except in the color which is pure white. Already a universal favorite. Each 30c, 4 for $\$ 1.00$.

688 The Three Best Climbing Roses for $75 \mathrm{c}$

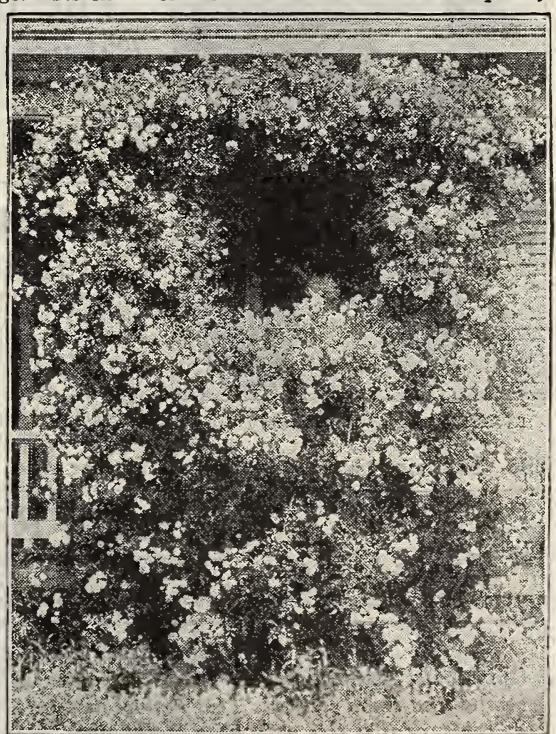

Dorothy Perkins Climbing Roses 


\section{A PAGE of SELECTED BERRY PLANTS}

We want our patrons to grow the very best varieties of Berries. We are not going to confuse you by offering a long list of varieties. We have therefore consulted a number of experienced growers, and as a result have selected the following varieties which we confidently believe to be the best in their respective classes. You can make no mistake by planting these varieties.

\section{The Best June Strawberry}

701 Gibson In Berrien County, Michigan, the second largest Strawberry County berries are extra large, of a beautiful red color and fine appearance. Gibson plants out-yield other varieties, and Gibson berries out-sell other berries on the market. This is certainly recommendation enough, but we want to add that it is also an extra nice table or home Strawberry. The plants are extra strong growers. They commence to ripen medium early and continue for a long season, making a heavy yield. Growers reported as high as $\$ 700$ per acre last season. Whether for home use or for market, you will make no mistake by planting Gibson. Price postpaid, 25 for 50 c, 50 for $85 c, 100$ for $\$ 1.50,1000$ for $\$ 10.00$.

\section{The Best Red Raspberry}

702 Early King This is an extra early red Raspberry. It is a week or ten days

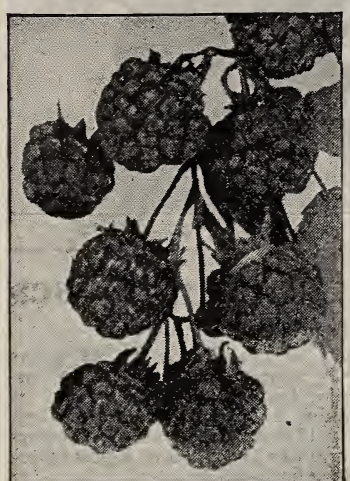

Early King Raspberry large, bright-red, firm and easily picked. The canes are strong and perfectly hardy. One grower says Early King is the earliest and most beautiful

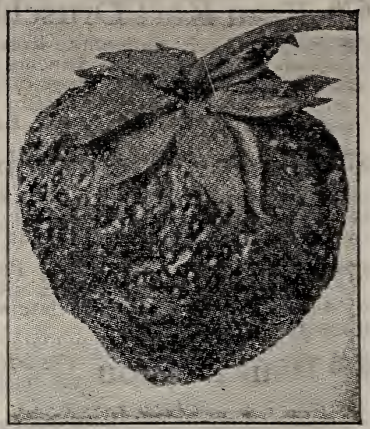

Gibson Strawberry variety it is a money-maker as you get the early market ahead of the big shipment of other varieties. Price, 6 for $45 c, 12$ for $85 c, 50$ for $\$ 2.75,100$ for $\$ 5.00$.

\section{The Best Black Cap Raspberry}

703 Cumberland The "BUSINESS BLACK CAP." Biggest black Raspberry profitable and desirable variety for home or market. Cumberland is very hardy everywhere. Extra productive, being the heaviest bearing variety in cultivation. Fruit is extra large, jet black and of superior quality. Ripens medium early. This is the Standard Black Cap Raspberry, being more extensively grown than any other variety. Price, 6 for $45 c, 12$ for $85 c, 50$ for $\$ 2.75,100$ for $\$ 5.00$.

\section{The Best Blackberry}

704 Eldorado This popular hardy Blackand more largely grown than any other because of its berry is known everywhere ability. Where other varieties often fail by winter killing, Eldorado can always be depended on for an abundant crop It is the Blackberry for every fruit grower. It is enormously productive, large, sweet and free from core. Price, 6 for 50c, 12 for $90 \mathrm{c}, 50$ for $\$ 3.50,100$ for $\$ 6.00$.

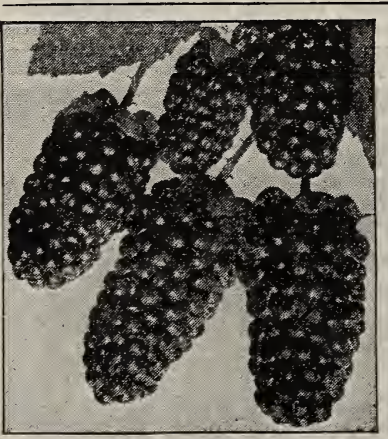

Eldorado Blackberry

\section{The Best Dewberry} 705 Lucretia The most largely grown of or market. It is a trailing species of Blackberry. It is earlier than the earliest Blackberry and

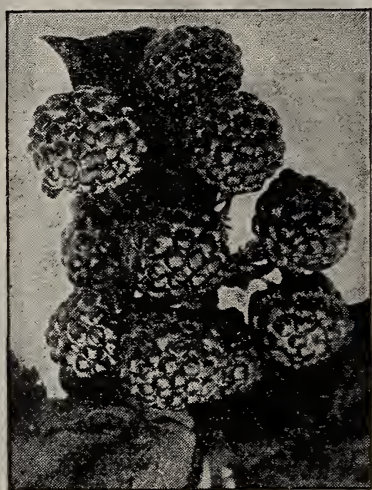

Cumberland Raspberry larger than the largest of them. The trailing canes are hardy everywhere and free from disease. The fruit is superb, large and handsome. Jet black, sweet and melting. Price, 6 for 50 c, 12 for $90 \mathrm{c}, 50$ for $\$ 2.75,100$ for $\$ 5.00$.

\section{Asparagus Roots}

Columbian Mammoth Every garden should contain an Asparagus bed Once planted it will require little care, and there is no other vegetable you can plant that will produce a greater quantity of such a tempting delicacy from the same space. An ordinary sized bed, 6 by 10 feet requiring 50 roots to plant, when established will furnish a daily supply for three persons for two months or more each season.

706 Strong two-year roots, 12 for 40 c, 50 for $\$ 1.00,100$ for $\$ 1.75$

\section{Rhubarb Roots}

707 Early Victoria A few clumps of Rhubarb in a corner of the garden will furing the early summer months. Strong one-year roots, 3 for 25 c, 12 for 75 c.

\section{Small Fruits Easy to Grow}

Our booklet "Better Gardens" gives complete instructions for growing all kinds of berries and small fruits. This booklet makes it easy for you. Price of booklet is 25 cents, or it is free with every $\$ 2.00$ order. Just ask for "Belter Gardens."

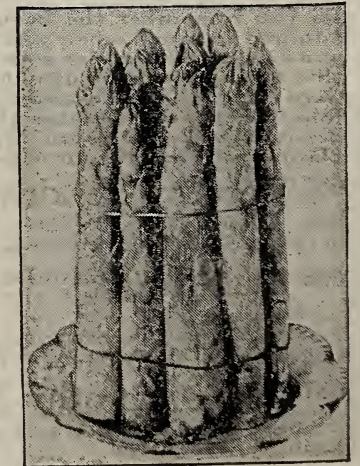

Asparagus 


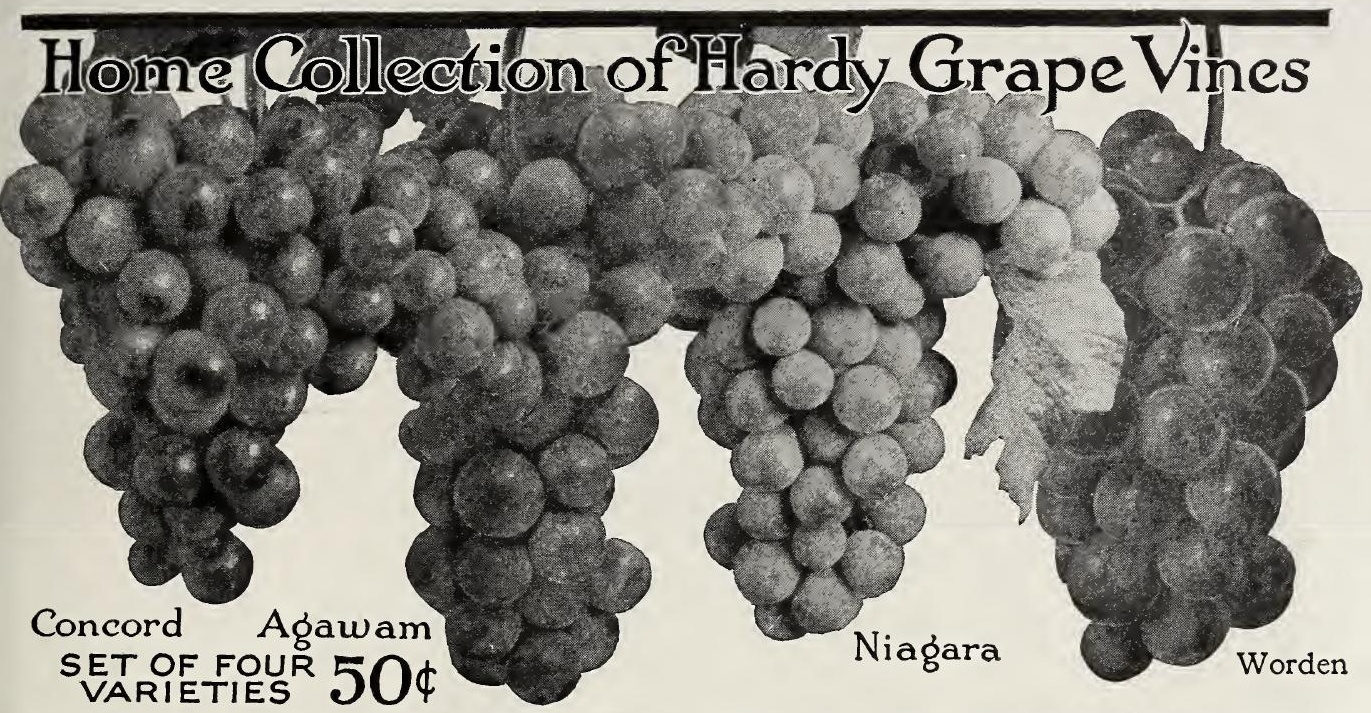

No item we list in this Catalog will give greater satisfaction than this splendid set of Hardy Grapes. Every home, if only on a city lot, can find room to plant them.

711 Agawam Berries large, on large compact bunches. Everybody should grow this variety. 15cts., 12 for $\$ 1.50$

712 Concord The best-known grape. Success everywhere.

713 Worden Large black berries, medium large bunch. able. Each 15 cts., 12 for $\$ 1.50$.

714 Niagara (White Concord). The best white grape 715 Strong, well-rooted, one-year-old vines, the set of 4 for $50 \mathrm{cts}$., postpaid and guaranteed.

Write for prices in quantities for planting vineyards

\section{New Everbearing Raspberry}

716 St. Regis A splendid new berry that is well worthy a place in every garden. A genuine, practical, profitable, productive, perpetual bearing variety. It produces an abundant main crop like the common varieties. The old canes continue to produce fruit until middle of August, when they should be removed to make room for the young canes, which are already beginning to ripen fruit, continuing in increasing quantities until last of October. The berries are bright crimson, of good size, and excellent quality. Strong, well-rooted plants.

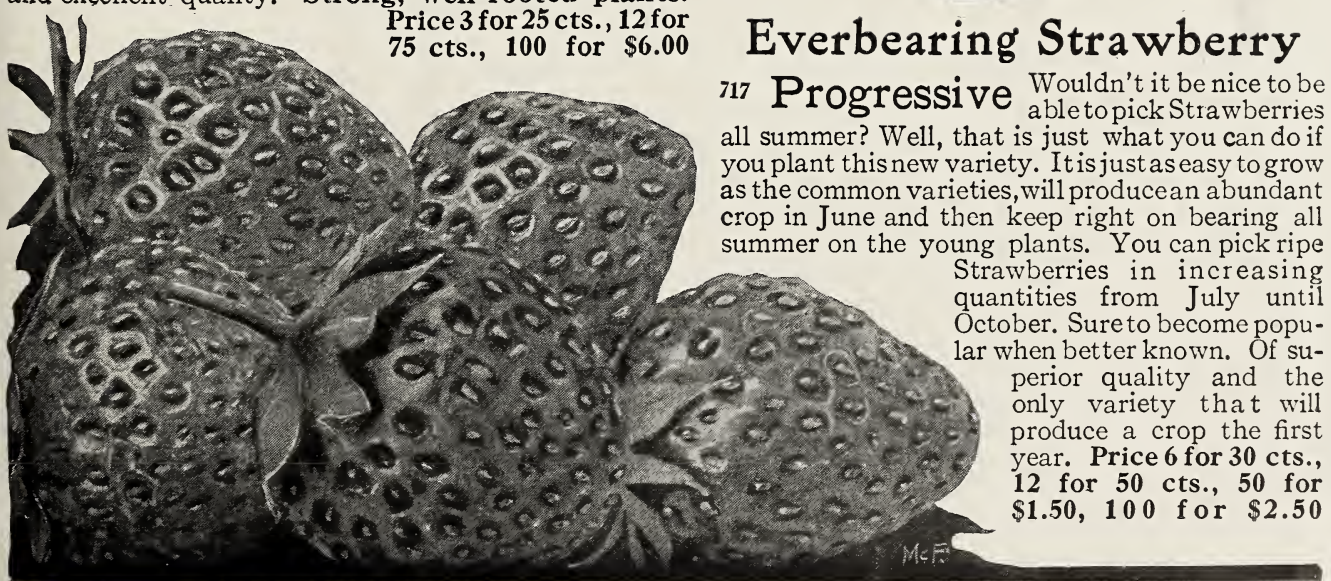
Price 3 for 25 cts., 12 for
75 cts., 100 for $\$ 6.00$ 


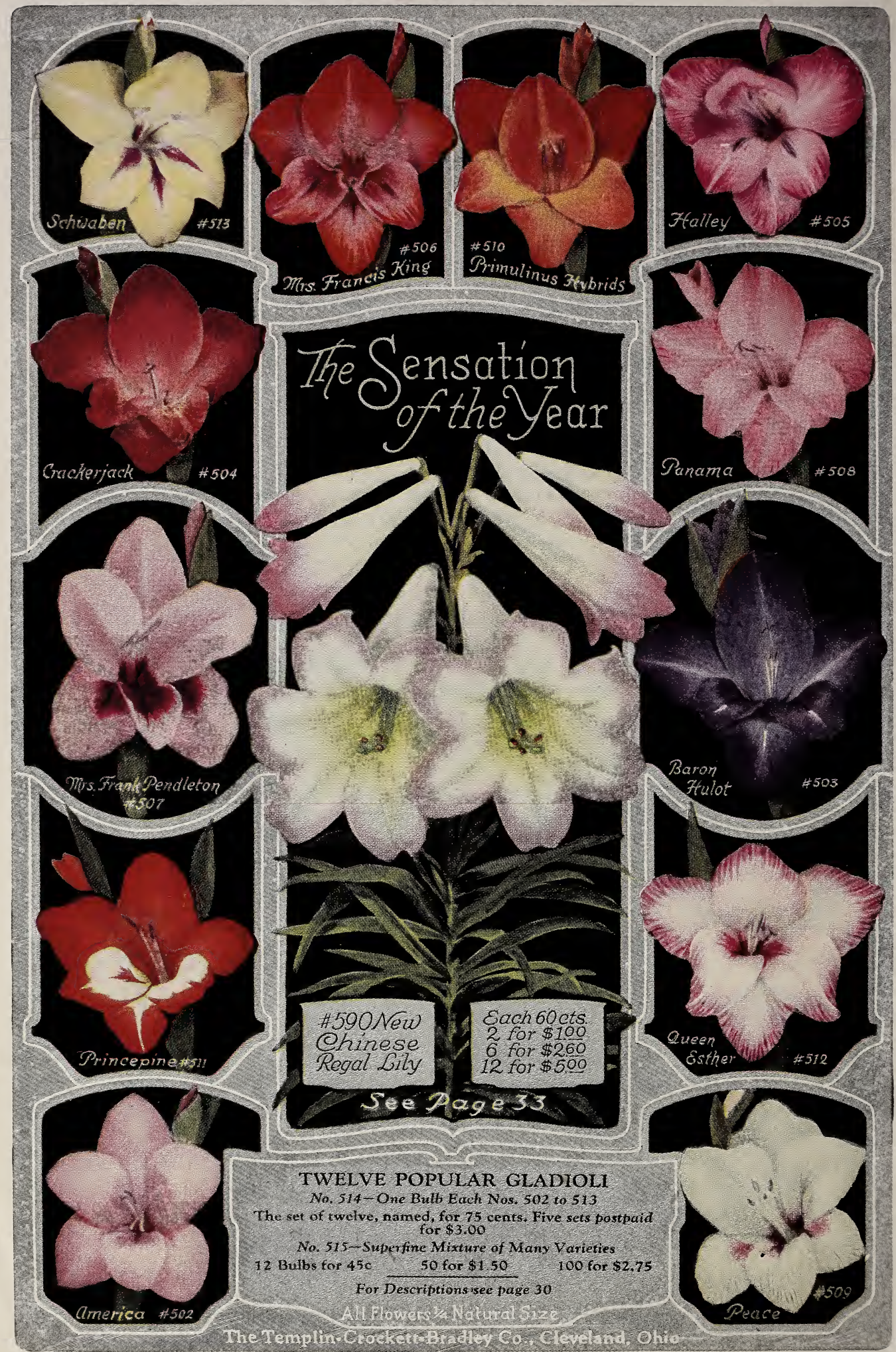

